PREPARATION OF CROSS-LINKED TYROSINASE AGGREGATES

A THESIS SUBMITTED TO

THE GRADUATE SCHOOL OF NATURAL AND APPLIED SCIENCES $\mathrm{OF}$

MIDDLE EAST TECHNICAL UNIVERSITY

BY

BURCU SELIN AYTAR

IN PARTIAL FULFILLMENT OF THE REQUIREMENTS

FOR

THE DEGREE OF MASTER OF SCIENCE

IN

CHEMICAL ENGINEERING

JUNE 2006 
Approval of the Graduate School of Natural and Applied Sciences

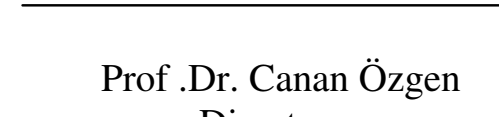

Director

I certify that this thesis satisfies all the requirements as a thesis for the degree of Master of Science

Prof. Dr. Nurcan Baç Head of Department

This is to certify that we have read this thesis and that in our opinion it is fully adequate, in scope and quality, as a thesis for the degree of Master of Science

Prof. Dr. Ufuk Bakır Supervisor

Examining Committee Members

Prof. Dr. Hayrettin Yücel (METU,CHE)

Prof. Dr. Ufuk Bakır

(METU,CHE)

Prof. Dr. Pınar Çalık

(METU,CHE)

Prof. Dr.Gülay Özcengiz ～(METU,BIOL)

Prof. Dr. Mehmet Mutlu (Hacettepe Unv.,FDE) 
I hereby declare that all information in this document has been obtained and presented in accordance with academic rules and ethical conduct. I also declare that, as required by these rules and conduct, I have fully cited and referenced all material and results that are not original to this work.

Burcu Selin Aytar

Signature: 


\title{
ABSTRACT \\ PREPARATION OF CROSS-LINKED TYROSINASE AGGREGATES
}

\author{
Aytar, Burcu Selin \\ M.S., Department of Chemical Engineering \\ Supervisor: Prof. Dr. Ufuk Bakır
}

June 2006, 82 pages

The aim of this study was to prepare cross-linked enzyme aggregate (CLEA) from crude mushroom (Agaricus bisporus) extract. However, the optimization of CLEA production was performed by using pure tyrosinase. Important parameters were determined as protein, ammonium sulfate and glutaraldehyde concentrations, CLEA particle size, and cross-linking temperature and period. On the other hand, the order of ammonium sulfate and glutaraldehyde addition did not affect the yield of CLEA. Optimum CLEA preparation conditions were $60 \%$ ammonium sulfate saturation, $2 \%(\mathrm{v} / \mathrm{v})$ glutaraldehyde, and 3 hour cross-linking reaction at room temperature. Particle size of the CLEAs should be reduced by mechanical stirring to eliminate mass transfer limitations. Under these circumstances, $100 \%$ recovery was obtained from both pure and crude tyrosinases. Optimum temperature and the activation energy for catechol oxidation were determined as $34{ }^{\circ} \mathrm{C}$ and $16.9 \mathrm{kcal} / \mathrm{mol}$ for CLEAs, whereas, $32{ }^{\circ} \mathrm{C}$ and $12.5 \mathrm{kcal} / \mathrm{mol}$ for the free enzyme. Furthermore, the thermostability of CLEAs was significantly higher than the free enzyme. CLEAs, prepared from crude mushroom extract, retained $72 \%$ of its maximum activity in 
eight months storage at $4{ }^{\circ} \mathrm{C}$. Moreover, changing the storage temperature from $4{ }^{\circ} \mathrm{C}$ to room temperature did not decrease CLEAs stabilities.

Keywords: cross-linked enzyme aggregate (CLEA), immobilization, tyrosinase, ammonium sulfate, glutaraldehyde 


\title{
ÇAPRAZ BAĞLANMIŞ TIROSINAZ ÇÖKELTILLERININ HAZIRLANMASI
}

\author{
Aytar, Burcu Selin \\ Yüksek Lisans, Kimya Mühendisliği Bölümü \\ Tez Yöneticisi : Prof. Dr. Ufuk Bakır
}

Haziran 2006, 82 sayfa

\begin{abstract}
$\mathrm{Bu}$ çalışmanın amacı ham mantar (Agaricus bisporus) özütünden çapraz bağlanmış enzim çökeltisi (ÇBEÇ) hazırlamaktır. Fakat, ÇBEÇ üretiminin optimizasyonu saf tirosinaz kullanılarak yapılmıştır. Önemli parametreler; protein, amonyum sülfat ve glutaraldehit konsantrasyonları, ÇBEÇ parçacık büyüklüğü, çapraz bağlama sıcaklığı ve süresi olarak belirlenmiştir. Öte yandan, amonyum sülfat ve glutaraldehitin eklenme sırası ÇBEÇ’in verimini etkilememiştir. Optimum ÇBEÇ hazırlama koşulları \% 60 doygunlukta amonyum sülfat, \% 2 (v/v) glutaraldehit ve 3 saat oda sıcaklı̆̆ında çapraz bağlama reaksiyonudur. Kütle aktarım kısıtlamalarını ortadan kaldırmak amacıyla ÇBEÇ'lerin parçacık büyüklükleri mekanik karıştırma ile küçültülmelidir. Bu koşullar altında hem saf hem de ham tirosinazdan \% 100 geri kazanım elde edilmiştir. Optimum sıcaklık ve katekolun oksitlenme aktivasyon enerjisi ÇBEÇ'ler için $34{ }^{\circ} \mathrm{C}$ ve $16.9 \mathrm{kkal} / \mathrm{mol}$, serbest enzim için de $32{ }^{\circ} \mathrm{C}$ ve 12.5 $\mathrm{kcal} / \mathrm{mol}$ olarak belirlenmiştir. Ayrıca, ÇBEÇ’lerin 1 sıl dayanıklılıkları serbest enzime göre çok daha yüksektir. Ham mantar özütünden hazırlanan ÇBEÇ’ler 4
\end{abstract}


${ }^{\circ} C^{\prime}$ de sekiz aylık bir depolamadan sonra maksimum aktivitelerinin \% 72'sini korumuşlardır. Ayrıca, depolama sıcaklığını $4{ }^{\circ} \mathrm{C}$ 'den oda sıcaklığına değiştirmek ÇBEÇ’lerin dayanıklılı̆̆ını azaltmamıştır.

Kelimeler: çapraz bağlanmış enzim çökeltisi (ÇBEÇ), tutuklama, tirosinaz, amonyum sülfat, glutaraldehit 
To My Family 


\section{ACKNOWLEDGEMENT}

First of all, I wish to express my deep and sincere gratitude to my supervisor, Prof. Dr. Ufuk Bakır for her valuable and encouraging guidance, supervision, and understanding throughout the research. Her wide knowledge and her logical way of thinking have been of great value for me.

I would like to thank Prof. Dr. Pınar Çalık for her help throughout the experimental studies in the laboratory.

My thanks also go to Central Laboratory, Molecular Biology and Biotechnology Research Center, METU and to Sibel Mete for microscope analyses. I wish to extend my thanks to Cengiz Tan and Metallurgical and Materials Engineering Department, METU for the SEM imaging.

My special thanks are due to Alev Deniz Öztürk, Ayşegül Ersayın Yeşinok, Aytaç Kocabaş, Beril Korkmaz Erdural, Didem Sutay, Özlem Ak, Arda Büyüksungur, Eda Çelik, and Hande Kaya for their friendship, support and help in the laboratory.

Finally, I want to express my deepest love and gratitude to my parents GülerHasan Aytar, and my brother Ümit Aytar and Gökhan Benli for their understanding, help, patience, and encouragement all through the study. 


\section{TABLE OF CONTENTS}

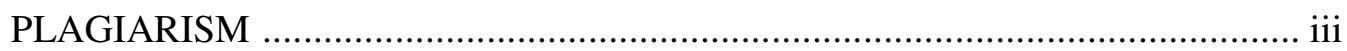

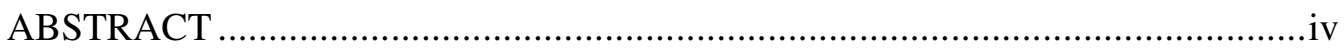

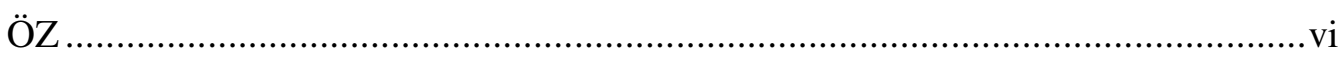

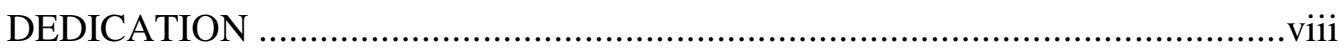

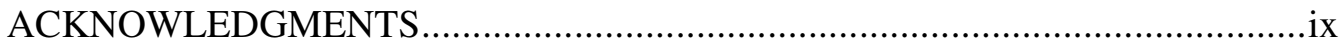

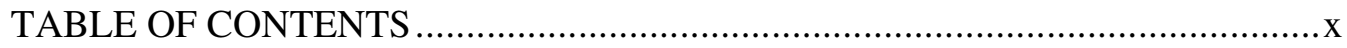

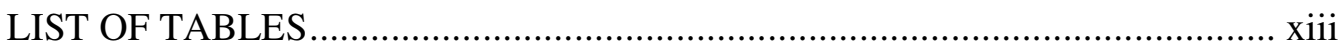

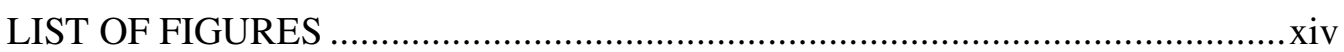

LIST OF ABBREVIATIONS .........................................................................

CHAPTER

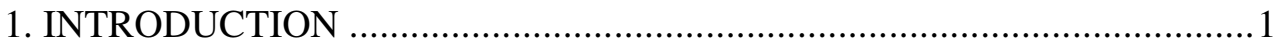

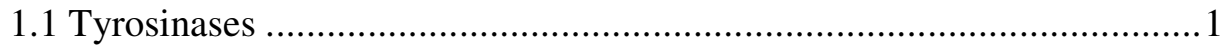

1.1.1 Biochemical Characteristics of Mushroom Tyrosinase ...............2

1.1.2 Active Site Characteristics of Mushroom Tyrosinase ................ 3

1.1.3 Application Areas of Tyrosinase .............................................4

1.2 Protein Precipitation .......................................................................

1.2.1 Precipitation by Increasing the Ionic Strength (Salting Out) .......6

1.3 Application of Glutaraldehyde in Enzyme Cross-linking ....................... 9

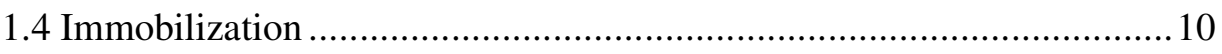

1.4.1 Carrier-bound Immobilization............................................ 11

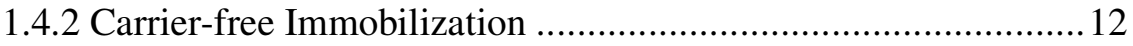

1.4.3 Carrier-bound Immobilized Mushroom Tyrosinases ................ 14

1.4.4 CLEAs of Different Enzymes............................................... 17

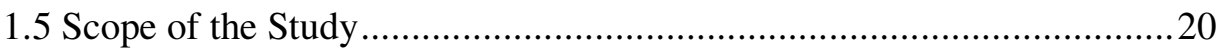

2. MATERIALS AND METHODS ..............................................................2 21

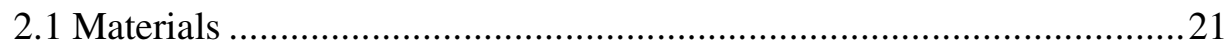


2.2 Analytical Methods

2.2.1 Activity Measurement of the Free Enzyme.............................21

2.2.2 Activity Measurement of CLEAs ............................................22

2.2.3 Protein Concentration Determination .....................................23

2.3 Image Analyses of CLEAs............................................................ 24

2.3.1 Scanning Electron Microscope (SEM) Images of CLEAs..........24

2.3.2 Microscope Images of CLEAs .............................................25

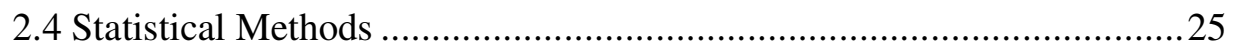

2.5 Crude Mushroom Extract Preparation...............................................25

2.6 Ammonium Sulfate Precipitation of Proteins .....................................26

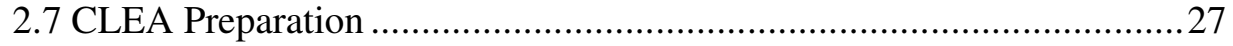

2.8 Characterization of Pure Tyrosinase CLEAs .......................................29

2.8.1 Optimum Temperature Determination...................................29

2.8.2 Activation Energy Determination........................................29

2.8.3 Thermal Deactivation Determination of free enzyme and CLEAs

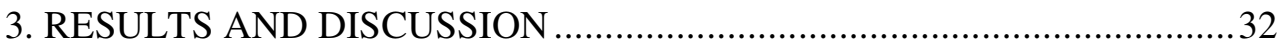

3.1 Preliminary Experiments Performed with Crude Mushroom Extract.....34

3.1.1 Investigation of the Interference of Ammonium Sulfate and Glutaraldehyde on the Enzyme Assay and Protein Concentration Measurement...................................................34

3.1.2 The Effect of Aging on Protein Precipitation.............................36

3.1.3 Effect of the Ammonium Sulfate Concentration on

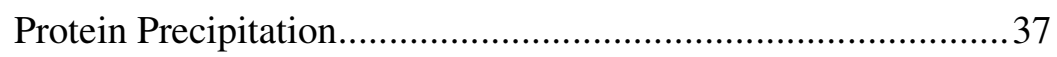

3.1.4 Preparation of CLEAs from Crude Mushroom Extract .............. 38

3.2 Optimization Studies with Pure Tyrosinase........................................40

3.2.1 Preparation of CLEAs from Pure Tyrosinase .............................40

3.2.2 Effect of the Protein Addition on the Enzyme Recovery

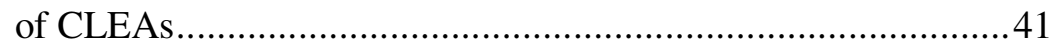

3.2.3 Effect of Ammonium Sulfate Concentration on CLEA

Production . .42 
3.2.4 Effect of the Glutaraldehyde Concentration on CLEA

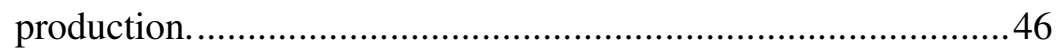

3.2.5 Effect of the Particle Size on CLEA Production ........................49

3.2.6 Effect of Simultaneous and Consecutive Addition of

Ammonium Sulfate and Glutaraldehyde on CLEA

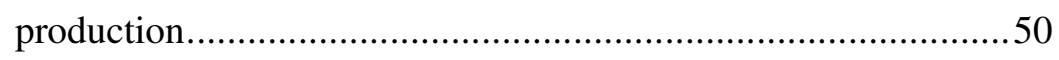

3.2.7 Effect of Cross-linking Conditions on CLEA Production ...........51

3.3 Characterization of CLEAs Prepared from Pure Tyrosinase ..................53

3.3.1 Temperature Dependence of the Free and Cross-linked

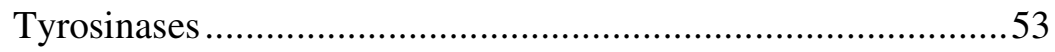

3.3.2 Activation Energies of Oxidation of Catechol by Free and Cross-

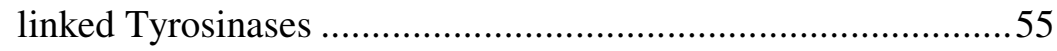

3.3.3 Thermal Deactivation of Free and Cross-linked Tyrosinases .....56

3.3.4 Storage Stability of the CLEAs Prepared from Pure

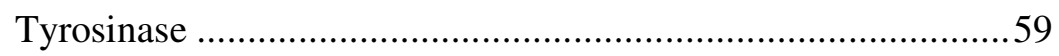

3.4 Preparation of CLEAs from Crude Mushroom Extract........................60

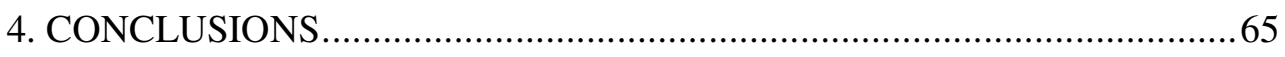

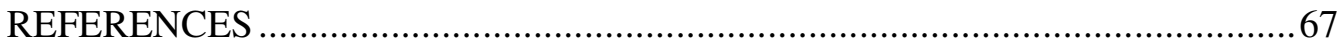

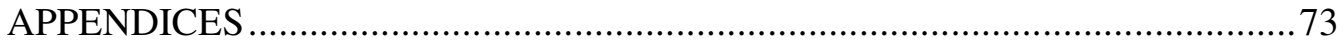

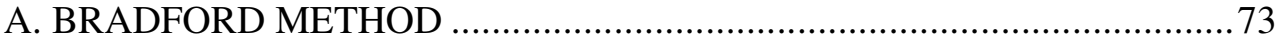

B. PROTEIN STANDARD PREPARATION FOR BRADFORD METHOD...75

C. FREE ENZYME INITIAL REACTION RATE CALCULATION ................77

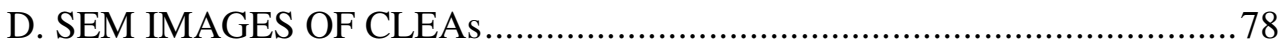

E. TWO-WAY ANOVA OF THE EFFECT OF STORAGE TEMPERATURE

ON THE CLEA ACTIVITY …....................................................... 82 


\section{LIST OF TABLES}

\section{TABLES}

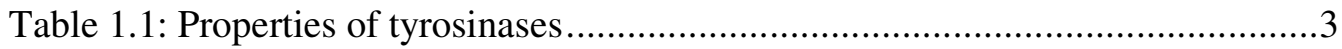

Table 3.1: Experimental steps and investigated parameters ..................................33

Table 3.2: Effects of the AS and GA on the enzyme assay and protein concentration

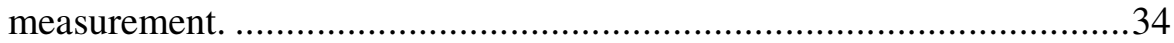

Table 3.3 The effect of aging on protein precipitation ........................................36

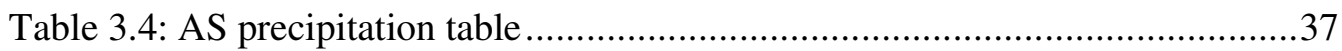

Table 3.5: Enzyme recovery of the CLEAs as a function of mixing period.............49

Table 3.6: Effect of the order of AS and GA addition...........................................51

Table 3.7: Optimum conditions for CLEA production from pure tyrosinase ............52

Table 3.8: Optimum temperatures of the free and immobilized tyrosinases obtained

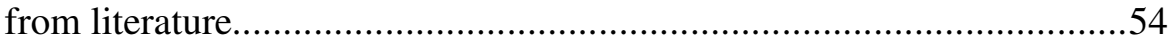

Table 3.9: Thermal deactivation of free enzyme and CLEAs at different temperatures

Table 3.10: Enzyme recoveries of CLEAs prepared from crude mushroom extract 61

Table 3.11: CLEAs prepared from crude mushroom extract before and after the

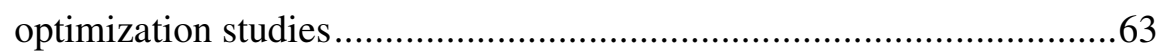

Table A.1: Chemicals required for the Bradford reagent ..................................73

Table B.1: Dilution ratios and concentrations of the BSA solutions........................75

Table E.1: ANOVA of the effect of storage temperature on the CLEA activity ......82 


\section{LIST OF FIGURES}

\section{FIGURES}

Figure 1.1: Reaction schemes of tyrosinase …..................................................

Figure 1.2: Schematic representation of the active site cupper atoms........................4

Figure 1.3: Amino acid sequences of the active sites of Mushroom tyrosinase ...........5

Figure 1.4: Different types of carrier-free immobilized enzymes ........................... 14

Figure 2.1: JSM-6400 Electron Microscope …....................................................24

Figure 2.2: Zeiss LSM 510 Confocal Microscope .................................................25

Figure 3.1: Color change of the crude mushroom extract by the addition of the AS

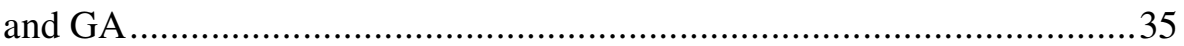

Figure 3.2: CLEAs obtained by using crude mushroom extract ..............................38

Figure 3.3: The effect of storage time on CLEA activity …......................................39

Figure 3.4: Effect of AS concentration on CLEA production.................................42

Figure 3.5: Effect of AS concentration on enzyme recovery ….............................43

Figure 3.6: Scanning Electron Microscope Images of CLEAs prepared with different AS concentrations (magnification $3500 \mathrm{x}$ ) ........................................45

Figure 3.7: The effect of GA concentration on CLEA production.............................46

Figure 3.8: The effect of GA concentration on enzyme recovery .........................47

Figure 3.9: Scanning electron microscope Images of CLEAs prepared with different

GA concentrations (magnification 3500x)

Figure 3.10: Microscope images of the CLEA particles after certain mixing times

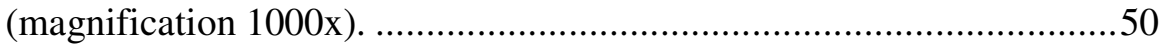

Figure 3.11: The effect of cross-linking conditions on CLEA production ................52

Figure 3.12: Effect of temperature on the activities of free and cross-linked tyrosinases

Figure 3.13 Arrhenius plots for the oxidation of catechol by the free and cross-linked tyrosinases 
Figure 3.14: Thermal deactivation of tyrosinase at different temperatures.

Figure 3.15: Storage stability of the CLEAs stored in two different temperatures .....59

Figure 3.16: The effect of GA concentration on CLEA production from crude mushroom extract ................................................................ 61

Figure 3.17: Storage stability of CLEAs prepared from crude mushroom extract. ....64

Figure B.1: Protein standard curve for the Bradford Method ..................................76

Figure C.1: Activity assay curve for the free enzyme …...................................... 77

Figure D.1: SEM Image of CLEA produced with $40 \%$ saturated AS (magnification

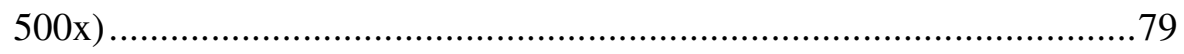

Figure D.2: SEM Image of CLEA produced with $60 \%$ saturated AS (magnification $500 x)$ .79

Figure D.3: SEM Image of CLEA produced with $80 \%$ saturated AS (magnification $500 x)$. .80

Figure D.4: SEM Image of CLEA produced with $1 \%$ (v/v) GA (magnification 500x)

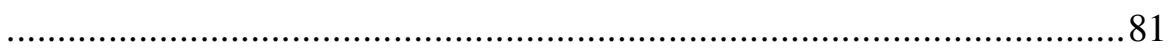

Figure D.5: SEM Image of CLEA produced with $2 \%$ (v/v) GA (magnification 500x) 


\section{LIST OF ABBREVIATIONS}

Abs: Absorbance

ANOVA: Analysis of variance

AS: Ammonium sulfate

BLC: Catalases from bovine liver

BSA: Bovine serum albumin

CLE: Cross-linked enzymes

CLEA: Cross-linked enzyme aggregates

CLEC: Cross-linked enzyme crystals

CSDE: Cross-linked spray-dried enzymes

DME : 1,2-dimethoxyethane

E.C.: Enzyme commission number

GA: Glutaraldehyde

GAC: Glutaryl acylase

$\mathrm{H}$ : Heavy chain of tyrosinase

HEMA-co-GMA: 2-hydroxyethyl methacrylate-co-glycidyl methacrylate

IgG: Immunoglobulin G

L: Light chain of tyrosinase

MBTH: 3-methyl-2-benzothiazolinone hydrazone

MLC: Catalases from Micrococcus lysodeikticus

MM: Menthyl monomer

MW: Molecular mass

PEG: Polyethylene glycol

PEI: Polyethyleneimine

PPO: Polyphenol oxidase

PPy: Polypyrrole

PVPP: Polyvinylpolypyrollidone 
SDS: Sodium dodecyl sulfate

SEM: Scanning electron microscope

$\mathrm{U}$ : Enzyme activity unit

$\varepsilon=$ extinction coefficient, $\frac{1}{\text { M.cm }}$

$\eta$ : Effectiveness factor 


\section{CHAPTER 1}

\section{INTRODUCTION}

\subsection{Tyrosinases}

Tyrosinase (EC 1.14.18.1, monophenol, o-diphenol: oxygen oxidoreductase, polyphenol oxidase) is a copper monooxygenase involved in the first steps of melanin synthesis from L-tyrosine leading to the formation of L-dopaquinone and Ldopachrome. This enzyme catalyzes o-hydroxylation of monophenols (cresolase activity or "monophenolase") and subsequent oxidation of the formed o-diphenols into reactive o-quinones (catacholase activity or "diphenolase"). In both of the reactions molecular oxygen is needed. Subsequently, the o-quinones undergo nonenzymatic reactions with different nucleophiles to produce intermediates which associate spontaneously in brown pigments (Halaouli et al., 2006; van Gelder et al., 1997). The reaction schemes are shown in Figure 1.1:

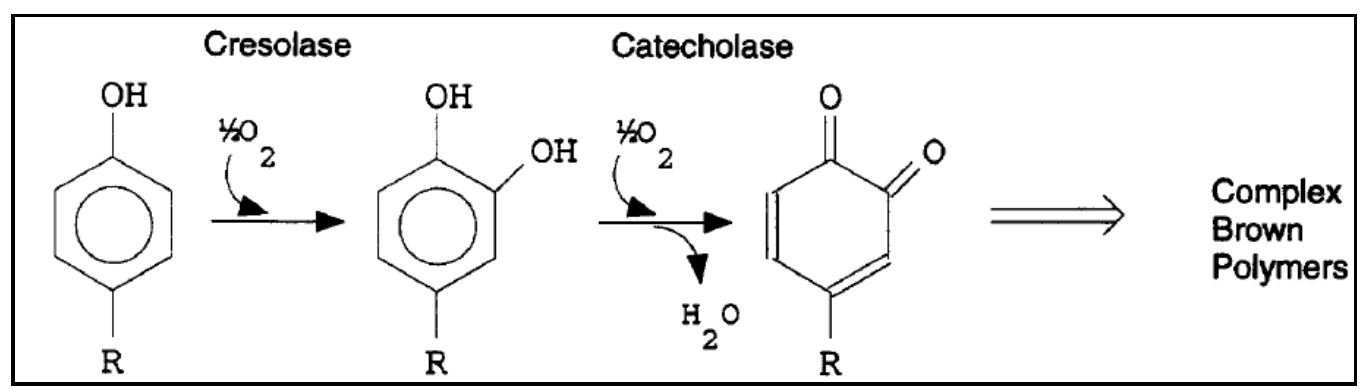

Figure 1.1: Reaction schemes of tyrosinase (van Gelder et al., 1997) 
Tyrosinases are found in mammals, invertebrates, plants and microorganisms with different biological functions (Halaouli et al., 2006). In mammals, they are involved in skin pigmentation. In insects, they are utilized in the exoskeleton sclerotization and protection against other organisms by encapsulating them in melanin. In plants, tyrosinases catalyze the formation of impervious melanin scab in order to protect them against the attacks of insects and microorganisms. Moreover, these enzymes are involved in the enzymatic browning of fruits and vegetables when their cells are bruised, cut or damaged. In addition, tyrosinases are also responsible in the development of distinct organoleptic properties of raisin, cocoa etc. (van Gelder et al., 1997). In fungi, tyrosinases are basically involved in browning and in pigmentation. Melanins protects against UV radiation, gamma rays, free radicals, extreme temperatures and dehydration. Furthermore, melanins provide additional fungal cell wall resistance against hydrolytic enzymes. Pigments are also used in the formation and stability of spores (Halaouli et al., 2006).

Since in this study cross-linked enzyme aggregates (CLEAs) were produced from mushroom (Agaricus bisporus) tyrosinase, the following sections are given for this type of tyrosinase.

\subsubsection{Biochemical Characteristics of Mushroom Tyrosinase}

Mushroom tyrosinase is suggested to have a molecular mass (MW) of 120$130 \mathrm{kDa}$. It is a heterotetramer, $\mathrm{H}_{2} \mathrm{~L}_{2}$, composed of two heavy chains $(\mathrm{H})$ with MW ca 43-45 $\mathrm{kDa}$ and two light chains (L) with MW ca 13-14 $\mathrm{kDa}$. The heavy chains contain the catalytic sites, however, the function of light chains is unknown (Jolivet et al., 1998). Some of the properties of tyrosinases are given in Table 1.1. 
Table 1.1: Properties of tyrosinases

\begin{tabular}{|c|c|c|c|c|c|}
\hline Reference & Substrate & $\mathbf{p H}$ & Temperature & $\mathbf{K}_{\mathbf{m}}$ & $\mathbf{V}_{\mathbf{m a x}}$ \\
\hline $\begin{array}{c}\text { Zhang et al., } \\
1999 \\
\text { (Cap flesh) }\end{array}$ & Catechol & 7 & - & $5 \mathrm{mM}$ & - \\
\hline $\begin{array}{c}\text { Arıca et al., } \\
2000\end{array}$ & L-tyrosine & 6.5 & $40{ }^{\circ} \mathrm{C}$ & 0.62 & $1890 \mathrm{U} / \mathrm{mg}$ \\
protein
\end{tabular}

\subsubsection{Active Site Characteristics of Mushroom Tyrosinase}

Tyrosinases can be divided into three domains, of which the central domain includes two cupper binding sites called as $\mathrm{Cu}_{\mathrm{A}}$ and $\mathrm{Cu}_{\mathrm{B}}$ (Seo et al., 2003). These active site cupper atoms are bound by three conserved histidine residues. The schematic representation of the binuclear cupper sites is shown in Figure 1.2. Tyrosinase interacts with molecular oxygen and phenolic substrates at these cupper sites (Van Gelder et al., 1997). 


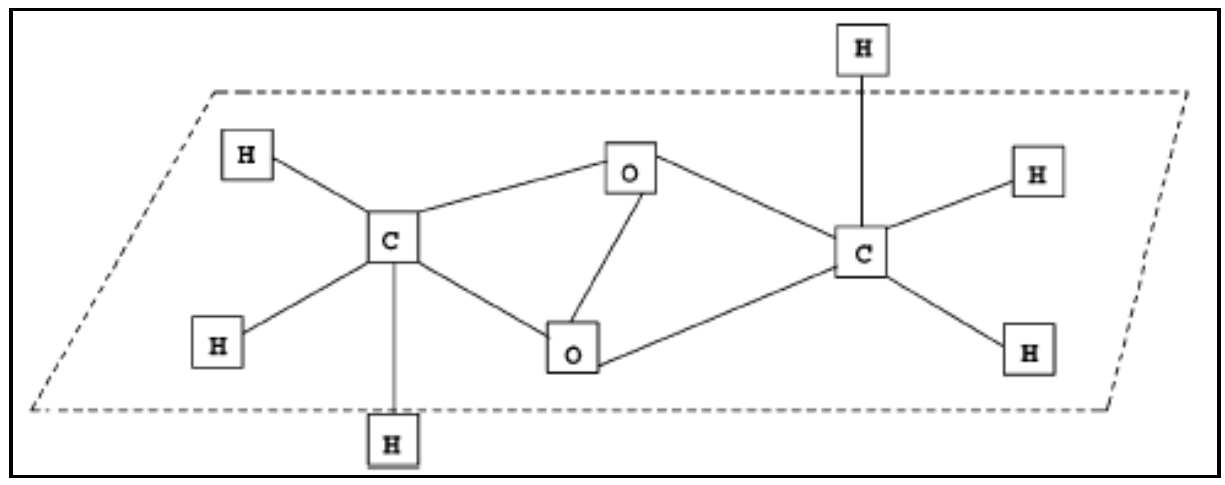

Figure 1.2: Schematic representation of the active site cupper atoms. C: $\mathrm{Cu}$ ion, O: oxygen, H: His-N, (Seo et al., 2003).

Two monomeric tyrosinases were isolated from fruitbodies of Agaricus bisporus strain U1 and these were encoded by two genes AbPPO1 and AbPPO2 (Halaouli et al., 2006). AbPPO1 is expressed constitutively, whereas the latter is an induced gene (Wichers et al., 2003). The amino acid sequences of the active sites, encoded by AbPPO1 and AbPPO2 are shown in Figure 1.3.

\subsubsection{Application Areas of Tyrosinases}

Tyrosinases are involved in the conversion of monophenols to diphenols, which can be used as antioxidants. For example, by utilizing p-coumaric acid as the substrate, tyrosinase as the catalyst, and ascorbic acid as the inhibitor against the quinone formation, caffeic acid can be produced. Moreover, hydroxytyrosol, which is also an antioxidant, can be synthesized under the catalytic action of tyrosinase from p-tyrosol, found in industrial by-products such as olive mill waste waters (Halaouli et al., 2006). 


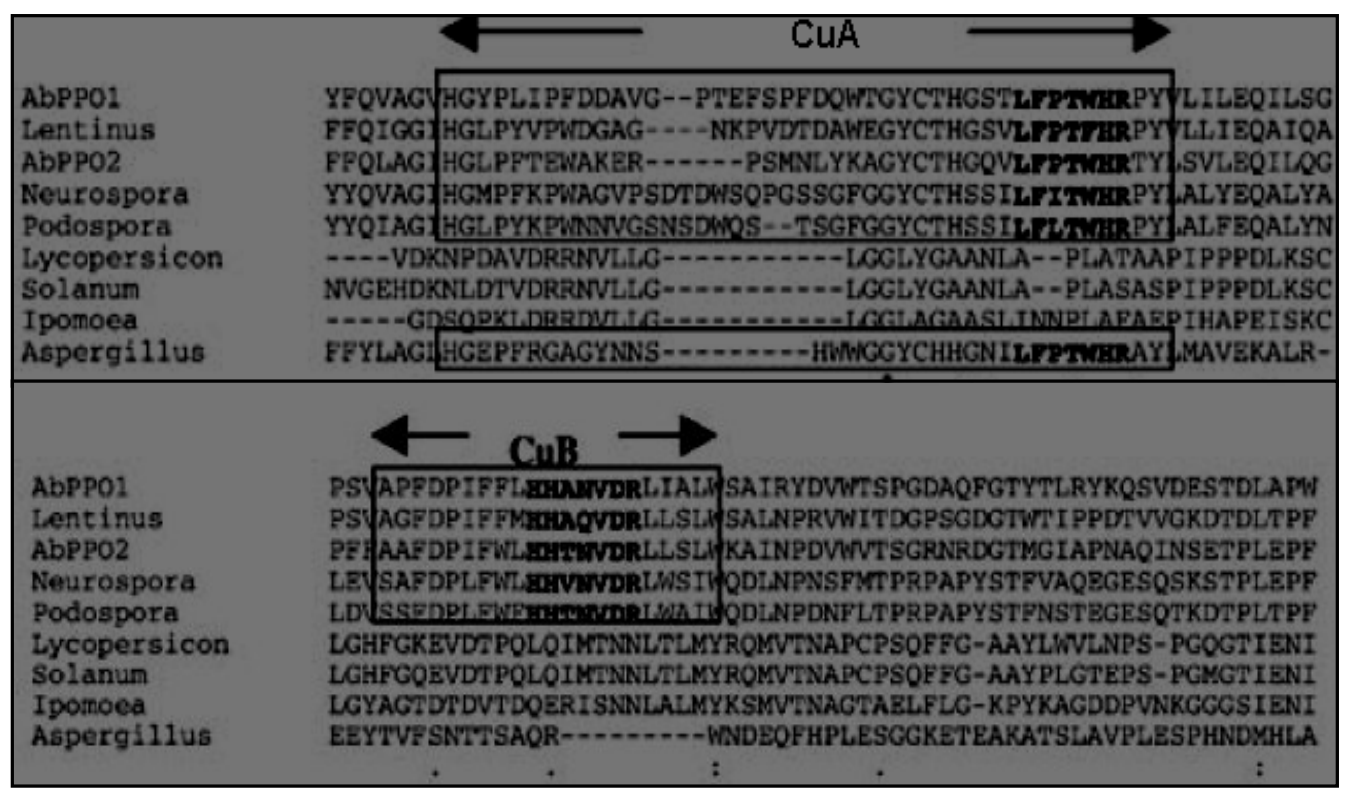

Figure 1.3: Amino acid sequences of the active sites of Mushroom tyrosinase. Cupper binding domains are shown in boxes and primers used are indicated in bold (Wichers et. al, 2003).

Phenols are observed in wastewaters of several industrial processes including coal conversion, petroleum refining, resins and plastics, wood preservation, and textile (Wang et al., 2002). Many of these phenols have toxic effects on animals and plants and cause environmental problems (Xue and Shen, 2002). Mushroom tyrosinases can be used for the precipitation and biotransformation of aqueous phenols (Halaouli et al., 2006). Moreover, to detect the phenolic compounds, biosensors based on tyrosinases can be developed (Xue and Shen, 2002).

\subsection{Protein Precipitation}

Precipitation is usually used as a crude separation step in the early stages of a purification procedure. Moreover, it is also used to concentrate proteins prior to analysis (Harris and Angal, 1989). 
The solubility of a protein in an aqueous solution depends on the distribution of the charged hydrophilic and hydrophobic groups on its surface. The charged groups on the surface interact with the ionic groups in the solution. Hydrophobic groups mainly present in the interior of the protein, however, substantial numbers reside on the surface, often in patches (Scopes, 1988; Harris and Angal, 1989).

Precipitation of proteins can be achieved by changing $\mathrm{pH}$ or ionic strength, or by adding organic miscible solvents, inert solutes or polymers (Harris and Angal, 1989).

Since in this study, proteins are precipitated by increasing the ionic strength, known as salting out, information about this type of precipitation was given.

\subsubsection{Precipitation by Increasing the Ionic Strength (Salting Out)}

The most commonly used method in the enzyme purification is the precipitation of proteins by using high concentrations of salts. Salting out depends on hydrophobicity of the surface of a protein. The hydrophobic patches consist of side chains of Phe, Tyr, Trp, Leu, Ile, Met, and Val amino acids. When these patches are forced into contact with aqueous solutions, water molecules becomes ordered and frozen around the side chains. When salt is added to the solution, water solvates the salt ions and as the salt concentration increases, water molecules are pulled off from the hydrophobic patches. Hydrophobic patches of one protein can interact with those of another, which results in aggregation. As a result, proteins with larger and higher amount of hydrophobic patches will aggregate before those with smaller and lower amount of patches, resulting in fractionation (Scopes, 1988; Harris and Angal, 1989).

Although salting out depends mainly on hydrophobic interactions, $\mathrm{pH}$ and temperature also affect protein solubility. $\mathrm{pH}$ can change the solubility, since by the removal of the charge, the surface can be made less polar. Aggregation can occur 
more easily near to the protein isoelectric point (Scopes, 1988). Moreover, by increasing the temperature, amount of the precipitation can be increased. However, in order to reduce the risk of inactivation, salting out is usually performed at $4{ }^{\circ} \mathrm{C}$ (Harris and Angal, 1989).

The nature of salt used in the precipitation is important. The salts with multicharged anions are the most effective ones. The order of effectiveness is phosphate> sulfate $>$ acetate $>$ chloride (and follows the Hofmeister series). Although phosphate is the most effective one, it consists of $\mathrm{HPO}_{4}{ }^{2-}$ and $\mathrm{H}_{2} \mathrm{PO}_{4}{ }^{-}$ions at neutral $\mathrm{pH}$ rather than the more effective $\mathrm{PO}_{4}{ }^{3-}$. In addition, monovalent cations are most effective with $\mathrm{NH}_{4}^{+}>\mathrm{K}^{+}>\mathrm{Na}^{+}$(Harris and Angal, 1989).

The salts used for the precipitation should possess some properties. First of all, it should be inexpensive with few impurities. Solubility of the salts should be high, since very high concentrations are required. Another consideration is the heat of the solution. Heating during the salt dissolving is not desired because of the risk of denaturation and change in solubility with temperature. Density of the solution is also important, since the separation of the precipitate by centrifugation depends on the difference between the densities of the aggregate and the solution (Harris and Angal, 1989).

Most potassium salts have low solubilities. Sodium citrate provides nearly no other advantage rather than to be used above $\mathrm{pH}$ 8.0. Moreover, sodium sulfate is not soluble at low temperatures. Except operating at high $\mathrm{pH}$, ammonium sulfate (AS) salt has many advantages and no disadvantage, at all (Scopes, 1988).

AS is the most commonly used salt. It is cheap and its solubility varies very little in the temperature range of $0-30{ }^{\circ} \mathrm{C}$. Saturated AS solution in pure water is approximately $4 \mathrm{M}$. It has a density of $1.235 \mathrm{~g} / \mathrm{ml} \mathrm{compared} \mathrm{to} 1.29 \mathrm{mg} / \mathrm{ml}$ of the protein aggregate in the solution (Scopes, 1988; Harris and Angal, 1989). 
One of the main advantages of AS precipitation is its stabilization effect on proteins. A protein precipitate in a 2-3 M AS solution is stable for years. Moreover, high salt concentrations prevent proteolysis and bacterial effects (Scopes, 1988).

AS concentrations are expressed as percent saturations by assuming the protein solution dissolves the same amount of salt as pure water. Usually, an AS cut is applied in order to achieve higher degree of purification. For this aim, initially, the protein solution is brought to a percent saturation where the desired protein does not precipitate. After removing the formed precipitate, more salt is added to the supernatant to precipitate the desired protein (Harris and Angal, 1989).

Determination of the necessary AS saturation is a compromise between activity recovery and purification degree. If the protein is valuable, or difficult to obtain, or the aim is to recover as much protein as possible without much concern for the purity, then purification degree can be sacrificed for recovery. However, if the precipitation is the first step in the purification procedures, recovery can be sacrificed for purity (Scopes, 1988).

AS can be added to the protein solution in the solid or in the solution form. During the addition of the salt, efficient stirring should be provided. Dissolved air can come from the solution and cause frothing, but this does not cause any harm, unless the overvigorous stirring itself causes frothing. In this case, surface tension effects on proteins can cause denaturation (Scopes, 1988).

The formed precipitate can be recovered by centrifugation and filtration after the equilibrium between the dissolved and aggregated proteins is completed at the end of 10-30 minutes (Scopes, 1988; Harris and Angal, 1989).

The pellet is dissolved in a buffer with a volume not more than 1-2 times of the volume of the precipitate. The redissolved pellet contains a significant amount of AS, which should be removed by desalting (Scopes, 1988; Harris and Angal, 1989). 


\subsection{Application of Glutaraldehyde in Enzyme Cross-linking}

Among the available cross-linking agents, glutaraldehyde (GA) has the wide application in different areas such as microscopy, leather tanning industry, enzyme technology, chemical sterilization, and biomedical and pharmaceutical sciences. GA is a linear, 5-carbon dialdehyde. It is colorless to pale straw colored, oily liquid which is soluble in water, alcohol, and organic solvents. Commercially available GA can exist in aqueous solution in its simplest monomeric dialdehyde form, but also as dimer, trimer, and polymer. This multiplicity in structure depends on solution conditions (Migneault et al., 2004).

GA is very reactive towards proteins at around neutral $\mathrm{pH}$. This reactivity depends on the presence of reactive functional groups in proteins and several molecular forms of GA in aqueous solution. As a result, there are many possible reaction mechanisms of cross-linking of proteins with GA (Migneault et al., 2004).

GA rapidly reacts with amino groups in a wide $\mathrm{pH}$ range $(\geq \mathrm{pH} 3.0)$. The reactions at $\mathrm{pH} 7.0$ and 9.0 are almost irreversible, although a little reversibility can occur. GA can also react with thiol group but only in the presence of primary amino group (Okuda et al., 1991).

GA is reactive toward the lysine residues in proteins. It also reacts with other amino acids, like tyrosine, tryptophan, phenylalanine, histidine, cysteine, proline, serine, glycine, glycylglycine, and arginine. The cross-linking of proteins either to a support matrix or between each other generally implies the $\varepsilon$-amino groups of lysine. Most proteins have high amount of lysine residues usually located on the surface of the proteins. Moreover, lysine residues are not generally found in the enzyme active site. As a result, after cross-linking the conformation and biological activity of the proteins can be preserved (Migneault et al., 2004). 
The reaction mechanism of GA with proteins has not yet clearly understood. However, since GA present in multiple forms, it can be concluded that there is no single mechanism for this reaction. The reaction of GA with enzymes depends on $\mathrm{pH}$, temperature, nature of enzyme, especially its lysine content, accessibility of different amino groups, particularly $\varepsilon$-amino groups of lysine, and the amount of enzyme and GA. There is an optimum $\mathrm{pH}$ for cross-linking, since the charges on protein may effect this reaction, which is maximum when the repulsive charges are minimum. The cross-linking reaction can be conducted at $4{ }^{\circ} \mathrm{C}$ for labile molecules, but in that case longer cross-linking times are required. Recently, the cross-linking reactions are performed at ambient temperatures for 4 hours or less. When low concentrations of enzyme and glutaraldehyde are used, the probability of the reaction of GA functional groups with the same enzyme molecule increases. As a result, conditions should be provided so that unwanted intramolecular cross-links are reduced. Moreover, low concentrations of GA are not enough to form sufficient cross-links to insolubilize enzymes (Bullock, 1984; Migneault et al., 2004).

\subsection{Immobilization}

High specifity, high rates of reaction, non-toxicity, water solubility, biodegradability, and use under mild conditions of $\mathrm{pH}$, temperature and pressure are the main advantages of enzymes over inorganic catalysts (Taylor, 1991). In order to facilitate the separation and recovery of enzymes, immobilization methods are used (Birnbaum, 1988). Immobilization means physical confinement or localization of enzyme molecules during a continuous catalytic process (Zaborsky, 1973). Immobilization brings many advantages. Since the immobilized enzymes can be easily recovered from the reaction medium and reused, the cost of the process reduces. In addition, the stability of the enzymes can be increased through multipoint attachment. Therefore, the operational lifetime of the immobilized enzymes is often prolonged. Mass transfer limitations are usually observed in immobilized enzymes.

In some instances, these limitations can be advantageous, for example, when 
substrate inhibition takes place. Immobilization can also change the optimal operation parameters such as $\mathrm{pH}$ and temperature which may be advantageous (Birnbaum, 1988).

Immobilized enzymes can be divided into two main groups; namely carrierbond and carrier-free (Cao et al., 2003).

\subsubsection{Carrier-bound Immobilization}

In the carrier-bound immobilization enzymes are associated with a support material, which limits their free movement. The various methods used in this type of immobilization are: adsorption, covalent coupling, entrapment, and encapsulation (Birnbaum, 1988).

Adsorption is based on ionic or hydrophobic interactions between the protein and supporting carrier. Since the binding is reversible, the support is regenerable. However, since in this method the forces between the enzyme and support are relatively weak, leakage of the enzyme from the support occurs (Birnbaum, 1988; Walsh, 2002).

The most often used method for immobilization is covalent coupling of the enzymes to the support matrix. The covalent nature of binding renders the immobilized enzymes very stable. As a result, the leaching of the enzyme from the matrix is minimal. In this method, since covalent bonds are formed between the groups present on the support surface and suitable groups of the enzymes, the latter functional groups must not play a role in the enzyme catalytic action (Walsh, 2002).

The third method of carrier-bond immobilization is the entrapment of proteins within a polymer network. This method is based on mixing of molecules to be 
immobilized with the solution of the polymer with subsequent polymerization (Birnbaum, 1988).

The last method is encapsulation, which is achieved by physical confinement of enzymes by using membranes (Birnbaum, 1988).

In the carrier-bound immobilization, the use of extra support matrix results in dilution of the immobilized enzyme activity due to its large amount of non-catalytic mass. As a result, lower space time yields and lower productivity values are unavoidable. Moreover, the design of the carrier-bound immobilized enzymes requires laborious and time consuming trial and error experiments (Cao et al., 2003).

\subsubsection{Carrier-free Immobilization}

In the carrier-free immobilized enzymes, there is no need for an extra, inactive carrier (Cao et al., 2003). As a result, these immobilized enzymes have high volumetric activities (Wilson et al., 2004). Carrier-free immobilized enzymes are prepared by cross-linking different enzyme samples, such as dissolved, crystalline, physically aggregated, and spray-dried enzymes to form cross-linked enzymes (CLEs), cross-linked enzyme crystals (CLECs), cross-linked enzyme aggregates (CLEAs) and cross-linked spray-dried enzymes (CSDEs), respectively (Cao et al., 2003). The schematic representation of these preparations is shown in Figure 1.4.

CLEs are obtained by directly cross-linking of dissolved enzymes. In spite of their enhanced thermostability, they have low activity retention, reproducibility, and mechanical stability (Cao et al., 2003).

CLECs are formed by cross-linking of compacted enzyme crystals. These preparations are highly active and have controllable size, changing from 1-100 $\mu \mathrm{m}$. They have enhanced thermal, $\mathrm{pH}$ and mechanical stabilities. However, in these 
preparations, there is the need for highly purified enzymes and a laborious crystallization step. Furthermore, this method has narrow applicability (Cao et al., 2003).

CLEAs were initially prepared by Cao et al. in 2000. In this method, enzymes are precipitated without disturbing their three-dimensional structure by changing $\mathrm{pH}$ or ionic strength, by the addition of organic miscible solvents, and inert solutes or polymers (Harris and Angal, 1989). The formed physical aggregates are then crosslinked by the addition of bifunctional cross-linkers (Cao et al., 2003).

CLEAs have comparable stability and activity to CLECs. Since protein precipitation is the most frequently used primary method for protein purification, during the preparation of CLEAs, there is no need for highly purified enzymes (Cao et al., 2003). This immobilization method is advantageous in its simplicity and robustness and provides the opportunity of coimmobilization of different enzymes (Mateo et al., 2004). Moreover, other benefits of the method are low cost and fast optimization opportunities (Van Langen et al., 2005).

Because of the above mentioned advantages, in this study, mushroom tyrosinase was immobilized via preparation of cross-linked enzyme aggregates. 


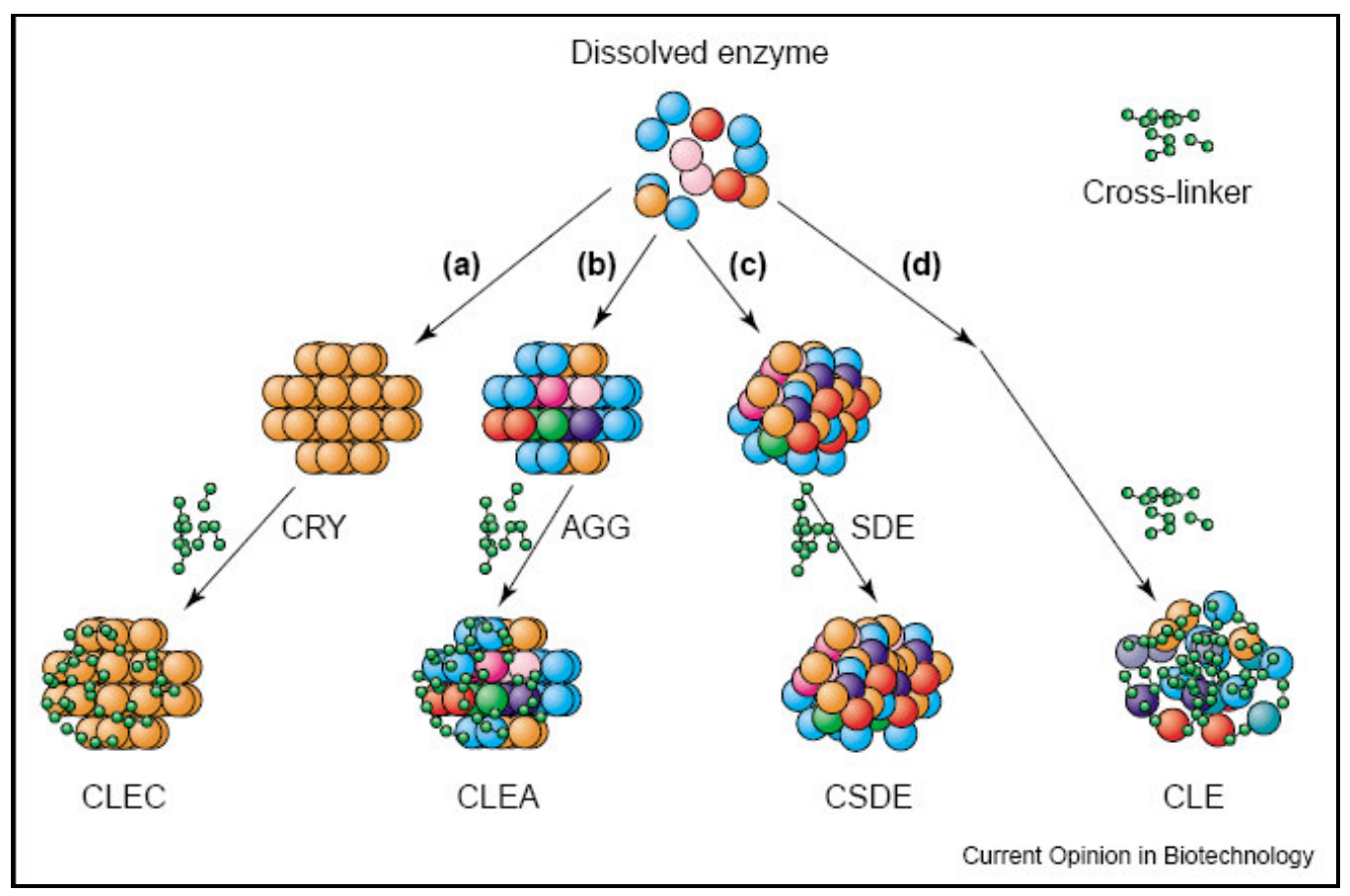

Figure 1.4: Different types of carrier-free immobilized enzymes. (a) crystallization, (b) aggregation, (c) spray-drying, (d) direct cross-linking. CRY: crystals, AGG: aggregates, SDE: spray-dried enzymes (Cao et al., 2003).

\subsubsection{Carrier-bound Immobilized Mushroom Tyrosinases}

Boshoff et al. (1998) immobilized mushroom polyphenol oxidase on nylon membrane by adsorption with GA cross-linking and on polyethersulphone membrane by adsorption. In non-immobilized and nylon membrane immobilized conditions, 4methylcatechol was produced. As a result, it was concluded that hydrophilic nylon membrane was a suitable matrix for the production of catechols from phenols. Whereas, in the reactions with polyethersulphone capillary membranes, phenols were converted to quinones. Since the produced quinones can be adsorbed from the reaction permeate, quinone inhibition of the immobilized enzymes could be lowered. 
Therefore, this system would be applicable to bioremediation of phenol-polluted water.

Edwards et al. (1999) immobilized polyphenol oxidase on chitosan coated and noncoated polysulphone capillary membranes. The level of phenol conversion was high with chitosan coated membrane since high amounts of the enzyme could be immobilized and formed quinones could be removed via adsorption on chitosan, which decreased o-quinone related inactivation of the polyphenol oxidase. Moreover, color generated by quinones was also removed by chitosan coating.

Arıca (2000) immobilized tyrosinase on carboxymethylcellulose beads through covalent bonding. Activity measurements were conducted by using Ltyrosine as the substrate. It was found that immobilized enzymes retained $44 \%$ of its initial activity. Optimum $\mathrm{pH}$ values for the free and immobilized tyrosinases were obtained as 6.5 and 7, respectively. Moreover, the optimum activities were measured at $40{ }^{\circ} \mathrm{C}$ for the free and at $45{ }^{\circ} \mathrm{C}$ for the immobilized enzyme. When the enzyme preparations were incubated at $60{ }^{\circ} \mathrm{C}$, immobilized and free tyrosinases lost all of their initial activities after 75 and 30 minutes, respectively.

Munjal and Sawhney (2002) entrapped tyrosinase in alginate, polyacrylamide and gelatin gels. The activities of both free and entrapped tyrosinases were determined by using tyrosine as the substrate and the maximum activity immobilization yields were found as $67 \%, 57 \%$ and $88 \%$ for the $\mathrm{Cu}$ alginate, polyacrylamide and gelatin gel entrapped tyrosinases, respectively. During storage at $-10{ }^{\circ} \mathrm{C}$, gelatin immobilized tyrosinases showed an increase in the activity for the first 7 days. This increase in the activity might be due to the changes in the lattice structure of the gel at the storage temperature, which might facilitate the diffusion of the reactants and products. The optimum $\mathrm{pH}$ and temperature values for the soluble enzyme, $\mathrm{Cu}$ alginate, polyacrylamide and gelatin gel entrapped tyrosinases were determined as 7 and $20{ }^{\circ} \mathrm{C}, 6.5$ and $35{ }^{\circ} \mathrm{C}, 7$ and $20{ }^{\circ} \mathrm{C}$, and 8 and $40{ }^{\circ} \mathrm{C}$, respectively. 
Kıralp et al. (2003) immobilized poylphenol oxidase (PPO) via entrapment in two electrodes, which are polypyrrole electrode (PPy/PPO) and the electrode prepared by copolymerization of menthyl monomer (MM) with pyrrole (MM/PPy/PPO). These electrodes were utilized in the determination of the phenolic compounds in wine. The optimum activities of the free and immobilized PPO in (PPy/PPO) and (MM/PPy/PPO) electrodes were measured at temperatures of 40, 40 and $60{ }^{\circ} \mathrm{C}$, respectively. When the activity measurement experiments were conducted by using catechol as the substrate, it was observed that immobilization has no effect on the rate of the product formation. The optimum $\mathrm{pH}$ of the free enzyme was measured as 5, and by immobilization of PPO, this value was increased to 7 and 9 for the (PPy/PPO) and (MM/PPy/PPO) electrodes, respectively. After 10 measurements, PPy/PPO electrode retained $60 \%$ of its initial activity, however, (MM/PPy/PPO) electrode still possessed $85 \%$ of its initial activity after 40 successive measurements.

Arıca and Bayramoğlu (2004) adsorbed tyrosinase on to polyethyleneimine (PEI) grafted and $\mathrm{Cu}$ (II) chelated poly (2-hydroxyethyl methacrylate-co-glycidyl methacrylate), poly(HEMA-co-GMA), membranes reversibly. Poly(HEMA-coGMA)-PEI-Cu (II) and poly(HEMA-co-GMA)-PEI membranes had activity recoveries of 78 and $64 \%$, respectively. This difference in activities was caused by increasing tyrosinase loading capacity of the membrane due to $\mathrm{Cu}$ (II) ions, which promoted adsorption of the enzyme. The optimum $\mathrm{pH}$ of the free enzyme was found as 6.5 and for the immobilized tyrosinase this value was shifted to 7 . In addition, the optimum temperatures of the free and immobilized tyrosinases were determined as 25 and $35{ }^{\circ} \mathrm{C}$, respectively. At $50{ }^{\circ} \mathrm{C}$, after 120 minutes of incubation, free enzyme retained $45 \%$ and poly (HEMA-co-GMA)-PEI-Cu (II) immobilized tyrosinase retained $86 \%$ of its initial activity. After three months of storage, adsorbed tyrosinases still possessed $46 \%$ of their initial activities.

Tyrosinase from partially purified mushroom extract was immobilized by Khan et al. (2005) on the immunoaffinity support, which was formed by bounding antityrosinase polyclonal antibody on the Seralose 4B. The effectiveness factor $(\eta)$ 
which was the ratio of actual to theoretical activity of the immobilized tyrosinase was found as 0.97 . After $120 \mathrm{~min}$ incubation at $55^{\circ} \mathrm{C}$, immunoaffinity bound tyrosinase retained $26 \%$ of its initial activity, whereas, free enzyme lost all of its activity after 10 min of incubation at the same temperature. Immobilized tyrosinase had a broader temperature-activity profile as compared to soluble tyrosinase with no difference in activity between 30 and $35{ }^{\circ} \mathrm{C}$. Whereas, the optimum temperature of the free enzyme was measured as $35{ }^{\circ} \mathrm{C}$. In the same manner, immunoaffinity bound tyrosinase showed a broadening in the $\mathrm{pH}$-activity profile as compared to soluble enzyme with no change of activity between $\mathrm{pH} 5.5$ and 6.0. On the other hand, free enzyme had an optimum $\mathrm{pH}$ of 6.0 .

Abdullah et al. (2006), immobilized tyrosinase in chitosan film prepared by spin coating method with a glass slide which was used as the supporting material. This preparation was utilized as an optical biosensor to detect phenols by using the color reagent MBTH. The optimum response of the optical biosensor was obtained at $\mathrm{pH}$ values between 6 and 7. Moreover, maximum response temperature of the sensor was determined as $45^{\circ} \mathrm{C}$.

\subsubsection{CLEAs of Different Enzymes}

Cao et al. (2000) prepared CLEAs of penicillin G acylase by using AS, tertbutyl alcohol and poly(ethylene glycol) (PEG) as the precipitating and GA as the cross-linking agents. Maximum free enzyme hydrolytic activity recovery was obtained nearly as $80 \%$ when tert-butyl alcohol was utilized. CLEAs of penicillin G acylase were also active in the synthesis of ampicillin in various organic solvents. In acetonitrile, CLEA preparations (produced with tert-butyl alcohol) are more active than CLECs on the basis of dry weight.

López-Serrano et al. (2002) used lipases from different species in the preparation of CLEAs. Enzymes are precipitated by AS in aqueous media, and by 
1,2-dimethoxyethane (DME) or acetone in organic solvents. In both of the media, GA was utilized as the cross-linker. CLEAs of Candida antarctica lipases, produced with DME or acetone, have activity yields (units found/units used $\times 100 \%$ ), exceeding $100 \%$ in the hydrolysis of p-nitrophenyl propionate, which might be due to inducement of a more active conformation by the precipitation conditions. Since lipases can be activated by using additives such as surfactants, crown ethers or amines, CLEAs were produced in the presence SDS, Triton X-100 and dibenzo-18crown-6. Since these additives also cause the lipases to adopt a more active conformation, hyperactivation was observed in some cases. For example, Candida antarctica lipase A CLEAs, prepared by AS precipitation, had activity yields of 98 , 162 , and $240 \%$ in the presence of no additive, SDS and triton, respectively.

Mateo et al. (2004) prepared CLEAs of oxynitrilase, nitrilases, alcohol dehydrogenase and penicillin $G$ acylase by using dimethoxyethane as the precipitating and low molecular weight GA and high molecular weight dextran polyaldehyde as the cross-linking agents. When the latter cross-linker was utilized, higher activity recoveries (with respect to free enzyme) were obtained. GA has a small size and is very reactive. It can penetrate to the enzyme active site and react with amino acids, necessary for the catalytic activity. As a result, inactivation with this cross-linker was observed.

Wilson et al. (2004) aggregated penicillin $G$ acylase with two hydrophilic polymers (polyethyleneimine and dextran sulfate) by using poly(ethylene glycol) as the precipitating and GA as the cross-linking agents. These polymers created a hydrophilic microenvironment around the enzyme molecules and promote the exclusion of the organic solvents out of the enzymes. As the polymer-to-protein ratio increased, stability of polymeric CLEAs in the organic solvents enhanced. Polymer containing CLEAs are slightly less thermal stable than the conventional CLEAs. As a result, it was concluded that polymers didn't contributed to the enzyme structural stabilization. The immobilization yields of the CLEAs were reported as 72, 61 and $52 \%$ corresponding to aggregates without any polymer, with small polymers and 
with large polymers, respectively. This difference in yields was explained by higher diffusion limitations in the polymeric CLEAs due to their higher particle sizes.

Wilson et al. (2004) prepared CLEAs from two tetrameric catalases (from bovine liver (BLC) and Micrococcus lysodeikticus (MLC)) by using diethyleneglycol-dimethyl ether as the precipitating and GA as the cross-linking agents. CLEAs of MLC and BLC recovered $40 \%$ and $45 \%$ of the offered activity, respectively. Quaternary structures of both catalases were stabilized by CLEA formation. Thermal inactivation of soluble enzyme was more rapid than the CLEA. The inactivation rate of the soluble enzyme depended on concentration, whereas, the concentrated and diluted CLEA samples had similar stabilities. At $60{ }^{\circ} \mathrm{C}$, after seven hours of incubation, BLC CLEA still retained more than $80 \%$ of its initial activity; on the other hand, at the same temperature and after the same time, the concentrated soluble enzyme retained about $35 \%$ of its initial activity.

López-Gallego et al. (2005) prepared CLEAs of glutaryl acylase (GAC) by using poly(ethylene glycol) as the precipitating and GA as the cross-linking agents. GAC had low amount of surface lysine groups which prevented sufficient crosslinking of the enzyme aggregate. In order to solve this problem, GAC was coaggregated with polyethyleneimine (PEI), a polymer having high amount of primary amino groups. After the aggregation step, primary amino groups of the PEI came closer to the ones of the enzyme which favored cross-linking between both of them. Without using the polymer, the formed CLEAs recovered only $14 \%$ of the initial enzyme activity. On the other hand, CLEAs with PEI recovered almost $60 \%$ of the initial activity.

Shah et al. (2006) prepared CLEAs of Pseudomonas cepacia lipase and of penicillin $\mathrm{G}$ acylase by adding bovine serum albumin (BSA) as proteic feeder in cases where the protein concentration of the enzyme solution is low and/or the enzyme activity is susceptible to the high concentration of cross-linker (GA) required to obtain aggregates. In the absence of BSA, only $50 \%$ of the free penicillin $\mathrm{G}$ 
acylase activity was recovered in the CLEA. On the other hand, by the addition of BSA, this recovered activity was increased to $86 \%$. Moreover, CLEAs with BSA were thermally more stable. For example, penicillin acylase CLEA, prepared in the presence of BSA, retained all of its initial activity after eight hours of incubation at $45{ }^{\circ} \mathrm{C}$.

\subsection{Scope of the Study}

The aim of this study was to prepare and characterize cross-linked enzyme aggregates (CLEAs) of tyrosinase from crude extracts of mushroom (Agaricus bisporus). These aggregates are going to be used in the biosensor applications and in biotransformation reactions such as dephenolization of olive oil mill waste waters.

Initially, CLEAs were prepared from crude mushroom extracts, and then, in order to determine the optimum parameters of CLEA production, cross-linked aggregates were produced from pure tyrosinase. After finding the effects of

precipitating and cross-linking agent concentrations, particle size of CLEAs, the order of the addition of precipitating and cross-linking agents, and cross-linking time and temperature; the CLEAs of pure tyrosinase were analyzed in terms of optimum temperature, activation energy of catechol oxidation, thermal and storage stabilities. Finally, by utilizing the parameters found with pure tyrosinase, CLEAs from crude mushroom extracts were again produced with high activity and stability. 


\section{CHAPTER 2}

\section{MATERIALS AND METHODS}

\subsection{Materials}

Mushroom tyrosinase (EC 1.14.18.1), glutaraldehyde (GA) (25\% solution), catechol, L-lysine, bovine serum albumin, brilliant blue $\mathrm{G}$ were purchased from SIGMA (St Louis, USA), and ammonium sulfate (AS) was obtained from MERCK (Darmstadt, Germany). Other reagents were of analytical grade and obtained from SIGMA or MERCK. Mushroom was bought from local supermarket.

\subsection{Analytical Methods}

\subsubsection{Activity Measurement of the Free Enzyme}

Activity measurement of tyrosinase was conducted spectrophotometrically by measuring the initial reaction rate of catechol oxidation with a double-beam UV-Vis spectrophotometer (Thermo Electron Cooperation Evolution 100). As the substrate, $0.1 \mathrm{M}$ catechol solution was prepared in $0.1 \mathrm{M}$, pH 7.0 sodium phosphate buffer. Enzyme samples were also diluted to the desired end concentrations with $0.1 \mathrm{M}, \mathrm{pH}$ 7.0 sodium phosphate buffer. Enzyme, substrate and buffer solutions were preincubated at $35{ }^{\circ} \mathrm{C}$. The reaction was started by the addition of catechol solution to the cuvette including the enzyme solution. The volume ratio of enzyme to the catechol solution was $1 / 1$. The blank contained buffer instead of enzyme solution. 
The change of absorbance was recorded at $420 \mathrm{~nm}$ in 5 seconds intervals for 35 seconds.

Initial reaction rates were calculated from the initial linear part of the reaction progress curve. Activity assays were repeated at least for two times.

One unit of the enzyme activity (U) was defined as $1 \mu$ mol product formed per minute at $420 \mathrm{~nm}$ under the given reaction conditions. The extinction coefficient for o-quinone formation from catechol at $420 \mathrm{~nm}$ was taken as $\varepsilon_{420}=3450 \mathrm{M}^{-1} \mathrm{~cm}^{-1}$ (Ögel et al., 2006). Equation 2.1 was used to calculate tyrosinase activity:

$$
\text { Enzyme Activity }=\left(\frac{\Delta \mathrm{OD}}{\Delta \mathrm{t}}\right)\left(\frac{1}{\varepsilon}\right)\left(1000 \frac{\mu \mathrm{mol}}{\mathrm{mmol}}\right)\left(2 \frac{\mathrm{ml} \text { reaction mixture }}{\mathrm{ml} \text { enzyme solution }}\right)\left(60 \frac{\text { seconds }}{\text { minute }}\right)
$$
$(\mathrm{U} / \mathrm{ml})$

Where;

$\Delta \mathrm{OD}=$ change in the absorbance at $420 \mathrm{~nm}$

$\Delta \mathrm{t}=$ change in the time

$\varepsilon=$ extinction coefficient, $\frac{1}{\text { M.cm }}$

\subsubsection{Activity Measurement of CLEAs}

Activity measurement of CLEAs was conducted spectrophotometrically by using a double-beam UV-Vis spectrophotometer (Thermo Electron Cooperation Evolution 100). Appropriate aliquots were taken from the CLEA suspensions and diluted with $0.1 \mathrm{M}, \mathrm{pH} 7$ sodium phosphate buffer to the desired end concentrations. 
$0.1 \mathrm{M}$ catechol in $0.1 \mathrm{M} \mathrm{pH} 7.0$ sodium phosphate buffer was utilized as the substrate solution. Enzyme suspension, substrate and buffer solutions were preincubated at 35 ${ }^{\circ} \mathrm{C}$ until they reach to thermal equilibrium. The reaction was started by the addition of the catechol solution to the enzyme suspension in $1 / 1$ ratio at $35{ }^{\circ} \mathrm{C}$ under stirring with a magnetic rod. After 5 seconds, $2 \times 1 \mathrm{ml}$ sample was taken from the reaction mixture and filtered through a filter paper (Schleicher \& Schuell Grade 589/1 black ribbon) into a $0.7 \mathrm{ml}$ quartz cuvette. Then the absorbance was recorded at $420 \mathrm{~nm}$. The blank contained buffer instead of enzyme solution. Finally, CLEA activity was calculated by using equation 2.1 .

The enzyme recovery in the CLEA was calculated as given in Equation 2.2:

$\begin{aligned} & \text { Enzyme } \\ & \text { Recovery, } \%\end{aligned}=\frac{\text { total activity of CLEA }(\mathrm{U})}{\text { total free enzyme activity used for CLEA production }(\mathrm{U})} \times 100$

To observe the interference of the precipitating and cross-linking agents on activity assay, free enzyme activities were also measured after 5 minutes of mixing of the enzyme with AS and GA solutions having final concentrations of $60 \%$ saturation and $2 \%(\mathrm{v} / \mathrm{v})$, respectively. Then the activity measurements were immediately performed.

\subsubsection{Protein Concentration Determination}

Protein concentration of the enzyme samples was determined by using Bradford method (Bradford, 1976) by using bovine serum albumin as the standard 
protein. The composition of the reagents is given in Appendix A, and procedure and standard curve for the protein concentration are given in Appendix B.

To analyze the interferences of the AS and GA on protein concentration measurements, the enzyme solution was mixed with the above mentioned reagents in the final concentrations of $60 \%$ saturation and $2(\mathrm{v} / \mathrm{v}) \%$, respectively. After 5 minutes of mixing, Bradford method was applied immediately.

\subsection{Image Analyses of CLEAs}

\subsubsection{Scanning Electron Microscope (SEM) Images of CLEAs}

$10 \mu \mathrm{l}$ of CLEA suspension was spread over a microscope slide. After drying at room temperature, CLEAs were coated with gold. The SEM images were recorded with JSM-6400 Electron Microscope (JEOL), equipped with NORAN System 6 Xray Microanalysis System \& Semafore Digitizer, locating in Metallurgical and Materials Engineering Department, METU. This device is shown in Figure 2.1:

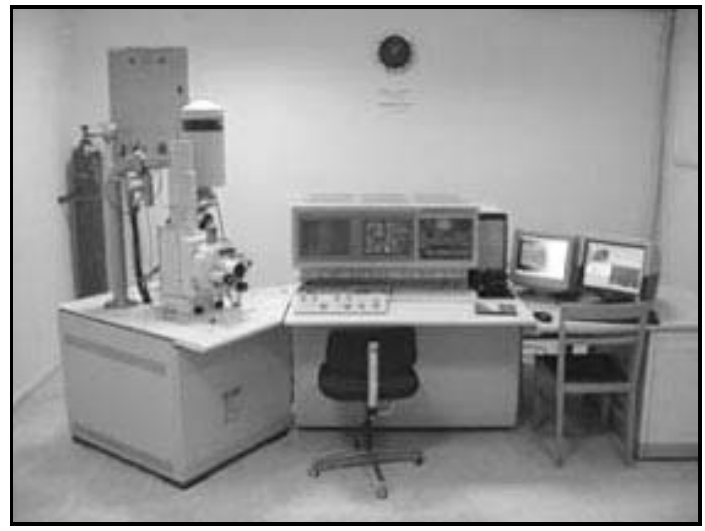

Figure 2.1: JSM-6400 Electron Microscope (JEOL) 


\subsubsection{Microscope Images of CLEAs}

Microscope images of CLEAs were taken with Zeiss LSM 510 Confocal Microscope. For this aim, $10 \mu \mathrm{l}$ of CLEA suspension was utilized. The microscope, locating in the Central Laboratory, Molecular Biology and Biotechnology Research Center, METU, is shown in Figure 2.2:

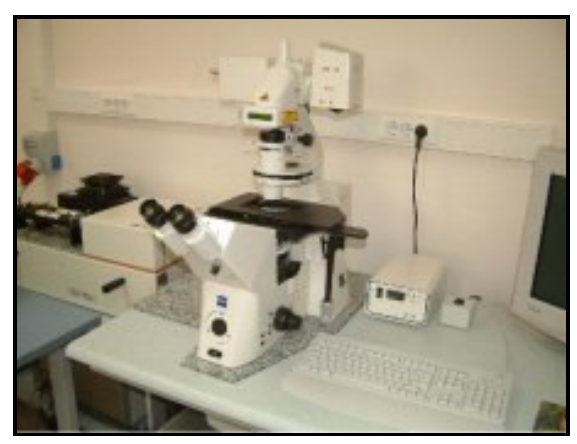

Figure 2.2: Zeiss LSM 510 Confocal Microscope

\subsection{Statistical Methods}

Statistical analysis of data was performed by ANOVA-two factor with replication by utilizing Microsoft, Excel.

\subsection{Crude Mushroom Extract Preparation}

Fruit bodies of the mushroom were obtained from local supermarket. After removal of stalks, the caps were washed and frozen at $-20{ }^{\circ} \mathrm{C}$. Then, $100 \mathrm{~g}$ of cap tissues were homogenized in $125 \mathrm{ml} 0.1 \mathrm{M}$, pH 7.0 sodium phosphate buffer, 
containing $2.5 \mathrm{~g}$ of polyvinylpolypyrollidone (PVPP), in a blender (ARÇELIKK Rollo K-1350) for about 2 minutes. PVPP can hydrogen bonds to the phenolic compounds present in the extract and prevent phenol-protein interaction (Smith and Montgomery, 1985). The obtained homogenate was centrifuged at $11000 \times \mathrm{g}$ for 10 minutes at $4{ }^{\circ} \mathrm{C}$ (SIGMA Laboratory Centrifuge 3K18). Supernatant containing the enzyme was filtered and the filtrate was used as the crude enzyme extract.

\subsection{Ammonium Sulfate Precipitation of Proteins}

Saturated AS solution was prepared by dissolving $70.7 \mathrm{~g}$ AS in $0.1 \mathrm{M}, \mathrm{pH} 7.0$ sodium phosphate buffer. Then, this solution was added to the crude enzyme extract up to the desired final concentration at $4{ }^{\circ} \mathrm{C}$ under efficient mixing to avoid formation of local areas of high salt concentration. After mixing, enzyme solution was centrifuged at $11000 \times \mathrm{g}$ for $15 \mathrm{~min}$ at $4{ }^{\circ} \mathrm{C}$. Pellet was dissolved in minimum volume of $0.1 \mathrm{M}, \mathrm{pH} 7.0$ sodium phosphate buffer and diafiltered with Vivaspin $15 \mathrm{R}$ Hydrosart concentrator at $6000 \times \mathrm{g}$ for 15 minutes at $4{ }^{\circ} \mathrm{C}$ by two times of buffer exchange. Then the pellet solution was analyzed in terms of the enzyme activity and protein concentration.

Yield, specific activity and purification fold for the pellets were calculated by using equations $2.3,2.4$, and 2.5 , respectively:

Yield $(\%)=\frac{\text { enzyme activity in the pellet }(\mathrm{U})}{\text { initial total enzyme activity }(\mathrm{U})} \times 100$

Specific Activity $(\mathrm{U} / \mathrm{mg})=\frac{\text { enzyme activity }(\mathrm{U})}{\text { total protein }(\mathrm{mg})}$ 
Purification (fold) $=\frac{\text { specific activity of the pellet }}{\text { specific activity of the free enzyme }}$

The effects of the AS concentration $(40,60,80$, and $90 \%$ saturation) and aging ( 5 minutes, 1 hour, 3 hours and overnight) were determined for tyrosinase precipitation.

\subsection{CLEA Preparation}

Initially, during the preliminary experiments, CLEAs were prepared from crude mushroom extracts. For this aim, into a centrifuge tube containing the enzyme extract (about $43 \mathrm{U}$ ), saturated AS solution was added up to the final concentration of $60 \%$ saturation. After 5 minutes of gentle mixing at $4{ }^{\circ} \mathrm{C}$, GA solution was added very slowly to the final concentration of $2 \%(\mathrm{v} / \mathrm{v})$. This mixture was stirred for 2.5 hours at $4{ }^{\circ} \mathrm{C}$ for the cross-linking reaction. Afterwards, the suspension was centrifuged at $13000 \times \mathrm{g}$ for 15 minutes at $4{ }^{\circ} \mathrm{C}$. The supernatant was stored for further enzyme activity and protein concentration analyses. The pellet was resuspended in $0.1 \mathrm{M}, \mathrm{pH} 7.0$ sodium phosphate buffer and it was centrifuged again to get rid of excess precipitating and cross-linking agents and unbound-enzyme. This washing and centrifugation procedure was performed until no enzyme activity was observed in the supernatant. Subsequently, washed CLEAs were resuspended in $8 \mathrm{ml}$ of $\mathrm{pH} 7.0$ sodium phosphate buffer and stored at $4{ }^{\circ} \mathrm{C}$ until use.

During the optimization studies, CLEAs were prepared from pure tyrosinase. Initially, the enzyme solution was prepared by dissolving $1 \mathrm{mg}$ pure tyrosinase (about $43 \mathrm{U}$ ) in $0.1 \mathrm{M} \mathrm{pH} 7.0$ sodium phosphate buffer. To analyze the effect of protein addition on the CLEA enzyme recovery, $50 \mathrm{mg} / \mathrm{ml}$ of bovine serum albumin (BSA) was added to the tyrosinase solution. Then, saturated AS solution was added to the desired end concentration into a centrifuge tube containing $0.2 \mathrm{ml}$ enzyme 
solution. After 5 minutes of gentle mixing at room temperature, GA solution was added very slowly to the enzyme solution. In the optimization studies, the effects of the AS and GA concentrations on CLEA recoveries were determined in the range of 0-90\% saturation and 1-4 \% (v/v), respectively. Moreover, the effects of the order of the precipitating and cross-linking agents' addition (consecutive or simultaneous addition), cross-linking period (3 hours and overnight) and temperature $\left(4{ }^{\circ} \mathrm{C}\right.$ and room temperature) were examined. After the cross-linking reaction, the suspension was centrifuged at $13000 \times \mathrm{g}$ for $15 \mathrm{~min}$ at $4{ }^{\circ} \mathrm{C}$. The recovered pellet was stored overnight in $0.1 \mathrm{M}$ L-lysine solution (prepared with $0.1 \mathrm{M}, \mathrm{pH} 7.0$ sodium phosphate buffer) to react with excess GA present (Tyagi et al., 1999). On the next day, CLEAs were recovered and washed via filtration. For this aim, the formed CLEAs were pipetted on to a filter paper (Schleicher \& Schuell Grade 589/1 black ribbon) and washed with $0.1 \mathrm{M} \mathrm{pH} 7.0$ sodium phosphate buffer until no enzyme activity was observed in the filtrate. Finally, washed CLEAs were removed from the filter paper, resuspended in buffer and stored at $4{ }^{\circ} \mathrm{C}$. To determine the effect of particle size on the CLEA activity, 1ml CLEA suspension was taken into an eppendorf tube. A small magnetic rod was inserted into the tube and the suspension was mixed in an ice bath. At the end of the 5, 25, 85 and 105 minutes, samples were taken and assayed for the tyrosinase activity and analyzed in terms of the particle structure by utilizing microscope.

After the optimization studies, CLEAs were again prepared from crude mushroom extract by using the optimized conditions. About $43 \mathrm{U}$ of the crude enzyme was mixed with $60 \%$ saturated AS and after 5 minutes, cross-linked with 0.1 and $2 \%(\mathrm{v} / \mathrm{v})$ GA solutions. After 3 hours of cross-linking reaction at room temperature, formed aggregates were stored in L-lysine solution for overnight and then washed via filtration as described in the CLEA preparation during the optimization studies. Finally, the formed CLEAs were finely dispersed in the $0.1 \mathrm{M}$, $\mathrm{pH} 7.0$ sodium phosphate buffer and stored at $4{ }^{\circ} \mathrm{C}$. 


\subsection{Characterization of Pure Tyrosinase CLEAs}

\subsubsection{Optimum Temperature Determination}

To determine the optimum temperature values of the free and immobilized pure tyrosinases, enzyme activities were measured at temperatures in the range of 25$35{ }^{\circ} \mathrm{C}$. By using a water bath (Nüve BM 302) attached to the cell holder of the UVVis spectrophotometer; enzyme, substrate $(0.1 \mathrm{M}$ catechol, prepared in $0.1 \mathrm{M} \mathrm{pH} 7.0$ sodium phosphate buffer) and $0.1 \mathrm{M}, \mathrm{pH} 7.0$ sodium phosphate buffer solutions were heated to the desired temperatures. After thermal equilibrium was reached, the activity measurements for both the free and immobilized tyrosinases were conducted as described in Sections 2.2.1 and 2.2.2, respectively.

The results for optimum temperature determination were given in relative form with the highest value being assigned as $100 \%$ activity.

\subsubsection{Activation Energy Determination}

Activation energies of oxidation of catechol by the free and immobilized pure tyrosinases were determined in the temperature range of $25-35{ }^{\circ} \mathrm{C}$. The initial reaction rates, obtained in the optimum temperature determination studies, were used to calculate activation energies.

Activation energies of oxidation of catechol were determined by using Arrhenius Equation.

For many reactions, the rate can be written as the product of the temperature and composition dependent terms as shown in Equation 2.6. 


$$
\begin{aligned}
& r=f_{1} \text { (temperature) } f_{2} \text { (composition) } \\
& =k \cdot f_{2} \text { (composition) }
\end{aligned}
$$

For such reactions, the reaction rate constant, which is the temperature dependent term, can be found by using Arrhenius Equation (2.7):

$$
\mathrm{k}=\mathrm{k}_{\mathrm{o}} \mathrm{e}^{-\mathrm{E} / \mathrm{RT}}
$$

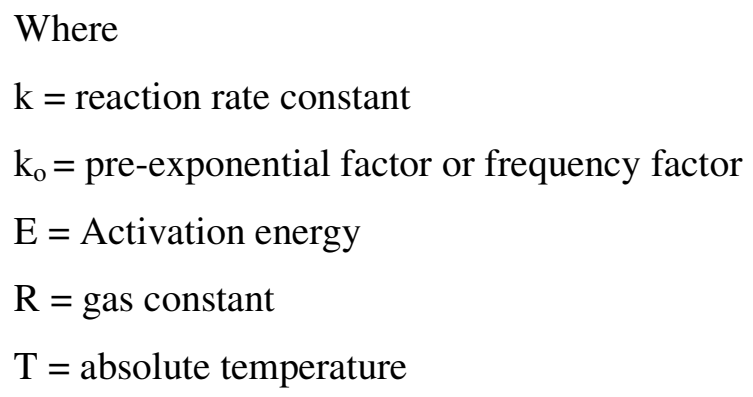

By taking the natural logarithm of both sites of Equation 2.7, Equation 2.8 was obtained:

$$
\ln \mathrm{k}=\ln \mathrm{k}_{\mathrm{o}}-\frac{\mathrm{E}}{\mathrm{RT}}
$$

At the same concentration, but at two different temperatures, Arrhenius equation shows that

$$
\ln \frac{\mathrm{r}_{2}}{\mathrm{r}_{1}}=\ln \frac{\mathrm{k}_{2}}{\mathrm{k}_{1}}=\frac{\mathrm{E}}{\mathrm{R}}\left(\frac{1}{\mathrm{~T}_{1}}-\frac{1}{\mathrm{~T}_{2}}\right)
$$


A plot of $\ln k$ versus $\frac{1}{T}$ gave a straight line with the slope of $-\frac{E}{R}$ (Levenspiel, 1999).

Therefore, ln of initial reaction rate versus $1 / \mathrm{T}$ graphs were constructed with a slope of $-\frac{E}{R}$, for both of the free and cross-linked tyrosinases.

\subsubsection{Thermal Deactivation Determination of free enzyme and CLEAs}

Thermal stability experiments of both the free and immobilized pure tyrosinases were conducted by incubating the enzyme solutions at 45,55 and $65{ }^{\circ} \mathrm{C}$ for various time intervals. At the end of incubations, samples were cooled in an ice bath and then heated to $35{ }^{\circ} \mathrm{C}$. Finally, the activities were measured and residual activities were calculated by taking the initial activity of the enzyme as $100 \%$. 


\section{CHAPTER 3}

\section{RESULTS AND DISCUSSION}

The aim of this study was to prepare and characterize cross-linked tyrosinase aggregates (CLEAs) of crude mushroom extract to be used in the biosensor applications for phenol detection and in biotransformation reactions such as in converting monophenols to o-diphenols and in the dephenolization of industrial waste-waters, etc. These immobilized enzymes were prepared by the addition of ammonium sulfate (AS) to the enzyme solution and cross-linking the formed aggregates by glutaraldehyde (GA).

In the preliminary experiments, as the enzyme, crude mushroom extract was used. Initially, the interferences of AS and GA on the enzyme assay and protein concentration measurements were determined. Then, precipitation conditions of the enzyme were optimized. For this aim, the effects of aging and AS concentration on protein precipitation were investigated. In the preliminary experiments, finally, CLEAs were prepared from crude mushroom extract. Although highly stable immobilized enzymes were produced, the yield was low.

To increase the yield, optimization studies were conducted. In these studies, pure tyrosinase was used to simplify the experiments. In the optimization experiments, the effects protein addition, AS and GA concentrations, aggregate particle size, the order of the precipitating and cross-linking agents addition, and finally cross-linking temperature and period on the activity of CLEAs were investigated. 
After obtaining highly active CLEAs of pure tyrosinase, these preparations were characterized in terms of optimum temperature, activation energy of catechol oxidation, and thermal and storage stabilities. Finally, the optimum CLEA production conditions were utilized for the preparation of CLEAs from crude mushroom extract again.

In Table 3.1, a summary of the experimental steps, and the parameters investigated in each step are given.

Table 3.1: Experimental steps and investigated parameters

\begin{tabular}{|c|c|c|}
\hline $\begin{array}{l}\text { Experimental } \\
\text { steps }\end{array}$ & $\begin{array}{c}\text { Type of the } \\
\text { enzyme } \\
\text { used }\end{array}$ & Investigated parameters \\
\hline $\begin{array}{l}\text { Preliminary } \\
\text { experiments }\end{array}$ & $\begin{array}{l}\text { Crude } \\
\text { mushroom } \\
\text { extract }\end{array}$ & $\begin{array}{l}\text { Interference of AS and GA on tyrosinase assay } \\
\text { and protein measurement, protein precipitation } \\
\text { conditions, enzyme recovery and storage } \\
\text { stability of CLEAs }\end{array}$ \\
\hline $\begin{array}{l}\text { Optimization } \\
\text { studies of CLEA } \\
\text { preparation }\end{array}$ & $\begin{array}{l}\text { Pure } \\
\text { tyrosinase }\end{array}$ & $\begin{array}{l}\text { The effects protein addition, AS and GA } \\
\text { concentrations, aggregate particle size, order of } \\
\text { AS and GA addition, cross-linking period and } \\
\text { temperature on the yield of CLEA }\end{array}$ \\
\hline $\begin{array}{l}\text { Characterization } \\
\text { studies of CLEAs }\end{array}$ & $\begin{array}{l}\text { Pure } \\
\text { tyrosinase }\end{array}$ & $\begin{array}{l}\text { Optimum reaction temperature, activation } \\
\text { energy of catechol oxidation, thermal and } \\
\text { storage stability of the CLEAs }\end{array}$ \\
\hline $\begin{array}{l}\text { CLEA } \\
\text { preparation }\end{array}$ & $\begin{array}{l}\text { Crude } \\
\text { mushroom } \\
\text { extract }\end{array}$ & $\begin{array}{l}\text { Enzyme recovery and storage stability of } \\
\text { CLEAs }\end{array}$ \\
\hline
\end{tabular}




\subsection{Preliminary Experiments Performed with Crude Mushroom Extract}

\subsubsection{Investigation of the Interference of Ammonium Sulfate and Glutaraldehyde on the Enzyme Assay and Protein Concentration Measurement}

To test the effects of the precipitating and cross-linking agents on the enzyme assay and protein concentration measurement, crude mushroom extract was mixed with AS and/or GA solutions and assays were immediately conducted without any centrifugation and dialysis steps. Experimental results are shown in Table 3.2.

Table 3.2: Effects of the AS and GA on the enzyme assay and protein concentration measurement. AS and GA were added to the enzyme solution to the final concentrations of $60 \%$ saturation and $2 \%(\mathrm{v} / \mathrm{v})$, respectively. After 5 minutes of mixing, measurements were performed.

\begin{tabular}{|c|c|c|c|c|}
\hline & Free enzyme & $\begin{array}{c}\text { Free enzyme } \\
+ \\
\text { GA }\end{array}$ & $\begin{array}{c}\text { Free } \\
\text { enzyme } \\
+ \\
\text { AS }\end{array}$ & $\begin{array}{c}\text { Free enzyme } \\
+ \\
\text { AS } \\
+ \\
\text { GA } \\
\end{array}$ \\
\hline $\begin{array}{c}\text { Tyrosinase } \\
\text { activity } \\
\text { (U/ml) } \\
\end{array}$ & $10.1 \pm 0.3$ & $9.0 \pm 0.3$ & $3.0 \pm 0$ & $0.8 \pm 0.1$ \\
\hline $\begin{array}{l}\text { Protein } \\
\text { content } \\
(\mathrm{mg} / \mathrm{ml}) \\
\end{array}$ & 0.4 & 0.5 & 0.4 & 5.0 \\
\hline
\end{tabular}

As seen from Table 3.2, GA slightly decreased the measured free enzyme activity. However, the activity reduction effect of AS was much more significant. 
GA (25\% aqueous solution) is a colorless liquid. However, when it was added, it darkened free enzyme solution. When GA and AS presented in the same solution, the darkening effect, therefore the interference was much more significant (Figure 3.1).

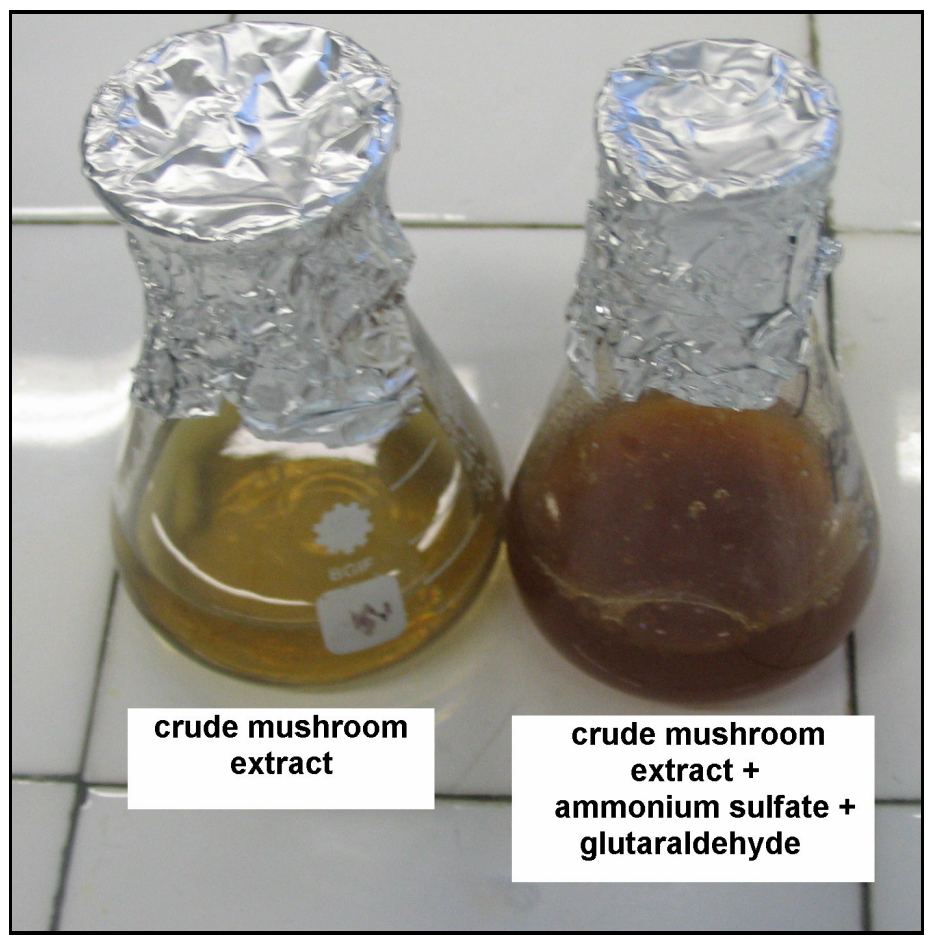

Figure 3.1: Color change of the crude mushroom extract by the addition of the AS and GA. Final AS and GA concentrations were $60 \%$ saturation and $2 \%(\mathrm{v} / \mathrm{v})$, respectively.

Since the presence of AS and GA interferes the enzyme assay and protein concentration measurement, these additives were completely removed from CLEA particles during the washing process, before the enzyme and protein assays. 


\subsubsection{The Effect of Aging on Protein Precipitation}

Schoevaart et al. (2004) reported an immediate (shockwise) aggregation of proteins, after the rapid addition of the precipitating agent solution. However, in some other studies, protein and AS was mixed for various time intervals, ranging from 10 minutes to overnight (Scopes, 1988; Munjal and Sawhney, 2002; Khan et al., 2005).

So, to determine the effect of aging (protein-AS mixing time) on protein precipitation, $90 \%$ saturated AS solution was mixed with crude enzyme at $4{ }^{\circ} \mathrm{C}$ for different time intervals. The results of this experiment are shown in Table 3.3.

Table 3.3: The effect of aging on protein precipitation. Pellets were obtained by precipitating crude mushroom extract with $90 \%$ saturated AS at $4{ }^{\circ} \mathrm{C}$.

\begin{tabular}{|c|c|c|c|c|}
\hline Precipitation mixing period & $5 \mathrm{~min}$ & 1 hour & 3 hours & overnight \\
\hline Yield, \% & $87 \pm 1.5$ & $84 \pm 1.3$ & $59 \pm 0.7$ & $50 \pm 1.9$ \\
\hline
\end{tabular}

As observed, as the contact time of the enzyme with the AS solution increased, the tyrosinase yield in the pellet decreased. Since the protective effect of AS on enzymes is known, the loss in the tyrosinase activity can be attributed to the shear effects generated by agitation. 


\subsubsection{Effect of the Ammonium Sulfate Concentration on Protein Precipitation}

In this part of the study, the effect of AS concentration on precipitation and partial purification was determined. For this aim four different AS concentrations; $60,70,80$ and $90 \%$ saturations were used. The experimental results are shown in Table 3.4.

Table 3.4: AS precipitation table. Precipitation was preformed at $4{ }^{\circ} \mathrm{C}$ for 5 minutes. Pellets were recovered via centrifugation and dialyzed before enzyme assay.

\begin{tabular}{|c|c|c|c|}
\hline $\begin{array}{c}\text { AS cut } \\
\%\end{array}$ & $\begin{array}{c}\text { Activity yield in pellet } \\
\%\end{array}$ & $\begin{array}{c}\text { Specific activity } \\
\text { U/mg }\end{array}$ & $\begin{array}{c}\text { Purification } \\
\text { (fold) }\end{array}$ \\
\hline 60 & $66 \pm 0.2$ & 32 & 2.1 \\
\hline 70 & $78 \pm 1.4$ & 23 & 1.5 \\
\hline 80 & $83 \pm 2.7$ & 17 & 1.2 \\
\hline 90 & $87 \pm 1.0$ & 15 & 1.1 \\
\hline
\end{tabular}

As seen from Table 3.4, at $90 \%$ of AS saturation, the highest yield was obtained; however, the purification fold was nearly half of that obtained by using 60 $\%$ saturation. Precipitating agent concentrations less than $60 \%$ were not used since in these cases lower activity yield would be obtained, which was not desired. The choice of the appropriate AS concentration should compromise between yield and purification. At $60 \%$ saturation, the highest purification was obtained with a reasonable yield.

Moreover, since these immobilized tyrosinases are desired to be used in industrial applications, they should be produced in large quantities. In order to 
minimize the production cost, minimum concentrations of AS should be used. Therefore, in the following experiments with crude mushroom extract, $60 \%$ AS saturation was utilized.

\subsubsection{Preparation of CLEAs from Crude Mushroom Extract}

In the preliminary experiments, the first CLEAs were produced from crude mushroom extract. The formed CLEAs are shown in Figure 3.2.

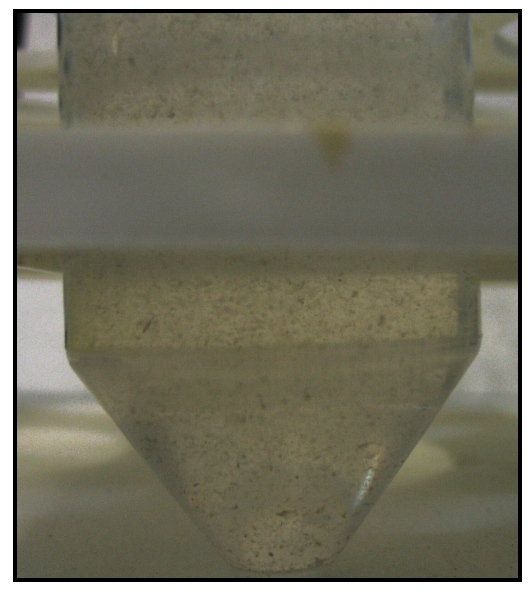

Figure 3.2: CLEAs obtained by using crude mushroom extract. CLEAs were produced by using $60 \%$ AS saturation, and $2 \%(\mathrm{v} / \mathrm{v})$ GA. After 2.5 hours of crosslinking reaction at $4{ }^{\circ} \mathrm{C}$, formed CLEAs were recovered via centrifugation.

The activities of the formed aggregates were measured at different time intervals of storage and enzyme recoveries are given in Figure 3.3. 


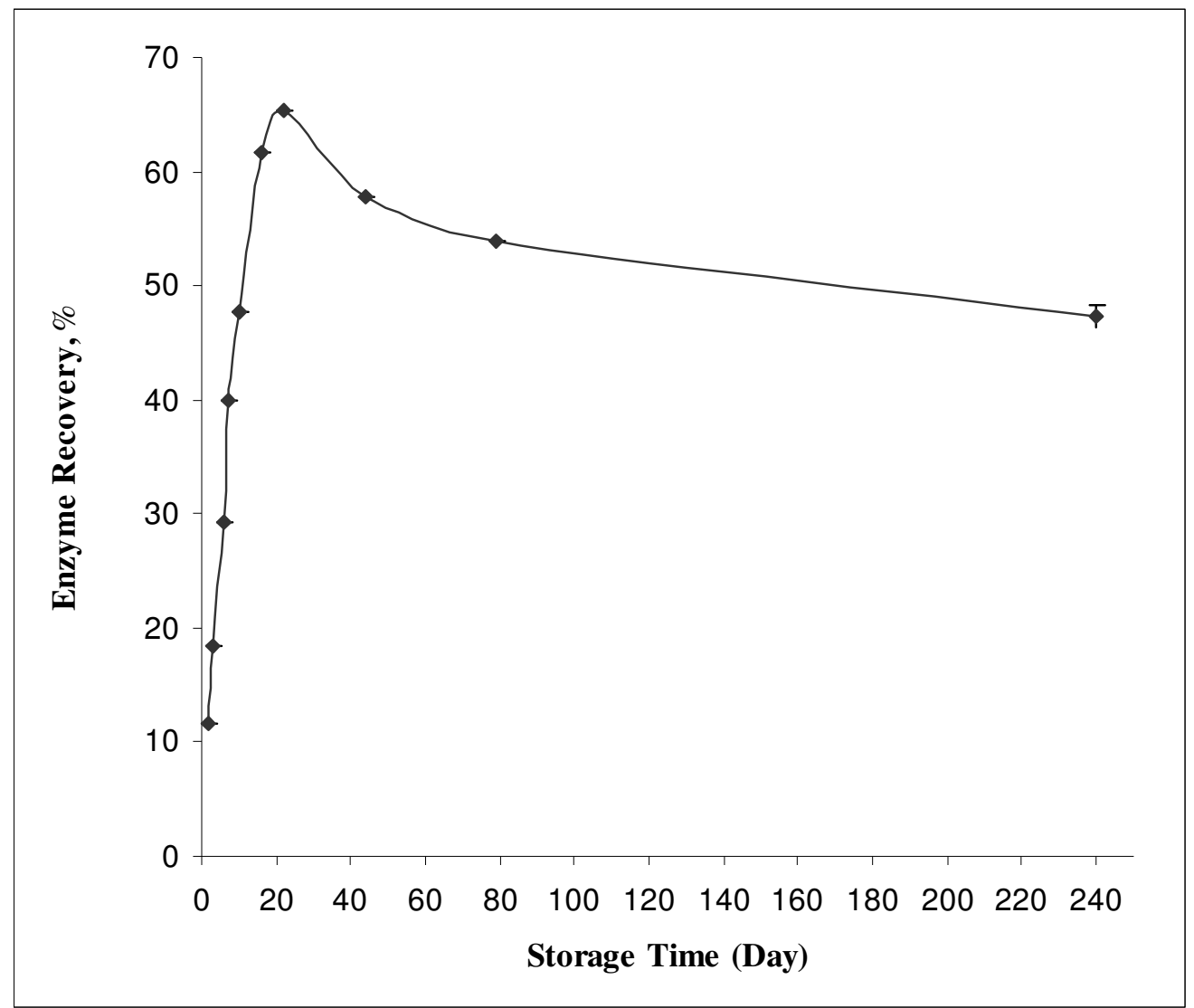

Figure 3.3: The effect of storage time on CLEA activity. Enzyme recovery was calculated as (total activity of CLEA)/(total free enzyme activity used for CLEA production $) \times 100$

During the recovery and washing of the formed cross-linked aggregates by centrifugation, particles were squeezed together which increased cluster formation and as a result mass transfer limitations. As time passes, CLEA particles held together by non-covalent bonds, probably separated from each other in the aqueous solution without loosing the enzyme activity. Therefore, during the initial period of storage, the activity recovery of CLEA's increased from $12 \%$ up to $65 \%$. After 8 months, the produced aggregates still retain $72 \%$ of their maximum activity. 


\subsection{Optimization Studies with Pure Tyrosinase}

\subsubsection{Preparation of CLEAs from Pure Tyrosinase}

As shown in Section 3.1.4, maximum $65 \%$ of the free enzyme activity was recovered in the CLEA. In order to determine the optimum conditions to increase the enzyme recovery, pure tyrosinase was used for CLEA preparation. Since pure enzyme does not include any contaminating proteins, the effect of many parameters on the CLEA activity could be determined more easily.

During the CLEA preparation from crude mushroom extract in the preliminary experiments, the CLEAs were recovered and washed via centrifugation. However, not all of the CLEA particles could be collected, although very high centrifugation speeds and periods were tried. Moreover, the pellet was not rigid; while removing the supernatant, it could be easily disturbed. As a result, some of the aggregates were lost during washing steps. In order to overcome these difficulties, the washing of the formed aggregates were continued with filtration.

The CLEAs of pure tyrosinase were prepared as described in Section 2.7, by AS (60\% saturation) addition and after 5 minutes of mixing, by GA (2\% (v/v)) cross-linking. After 3 hours of cross-linking reaction at room temperature, the produced CLEAs were stored in $0.1 \mathrm{M}$ L-lysine solution overnight to get rid of excess GA and finally, recovered and washed by filtration.

The maximum enzyme recovery with respect to free enzyme was obtained as $31 \%$, which was even lower than that obtained by using crude mushroom extract, 65 $\%$. The main difference in these two preparations was the total protein and impurity content. For the CLEAs prepared from the pure tyrosinase, the only protein was the enzyme without any impurity. However, crude mushroom extract composed of many different molecules containing other proteins in addition to tyrosinase. Therefore, the 
effect of protein addition on enzyme recovery of the CLEAs was investigated considering protein self protection at high concentrations.

\subsubsection{Effect of the Protein Addition on the Enzyme Recovery of CLEAs}

In order to analyze the effect of protein addition, bovine serum albumin (BSA), was used in addition to tyrosinase in the enzyme solution. BSA is available in various grades of purity and relatively cheap. Moreover, it has high lysine content. The addition of this inert protein to the enzyme solution has many advantages. GA can cross-link between enzyme and BSA. Therefore, the combination of the enzyme with this auxiliary protein results in the formation of high molecular weight, water insoluble complexes. This process facilitates the precipitation of the enzyme. In addition, direct cross-linking of the enzyme by GA results in low enzyme recoveries, which may be because of several reasons. First of all, excess cross-linking agent can act on amino groups located at or near the active site. Secondly, the formation of compact structures may result in the increase of the steric hindrances, and finally, excess cross-linking can reduce the conformational flexibility of the enzyme. The addition of BSA to the enzyme solution provides higher protein content for immobilization and reduces the above mentioned disadvantages (Broun, 1976).

To prepare cross-linked enzyme aggregates from pure tyrosinase with BSA, into $1 \mathrm{mg} / \mathrm{ml}$ enzyme solution, $50 \mathrm{mg} / \mathrm{ml} \mathrm{BSA} \mathrm{was} \mathrm{added} \mathrm{(Tyagi} \mathrm{et} \mathrm{al.,} \mathrm{1999).} \mathrm{The}$ further steps were the same as the CLEA preparation from pure tyrosinase.

The maximum enzyme recovery (wrt free enzyme) obtained in these CLEA

preparations was about $100 \%$. So, nearly all of the free enzyme activity was recovered with the addition of BSA. Thus, the experiments were continued by using $50 \mathrm{mg} / \mathrm{ml} \mathrm{BSA}$ in the enzyme solution. 


\subsubsection{Effect of Ammonium Sulfate Concentration on CLEA Production}

To analyze the effect of the AS concentration on the enzyme recovery of CLEAs, five different AS concentrations, 0, 40, 60, 80 and $90 \%$ saturations, were used. When GA was added to the enzyme solution in the absence of AS (0\% saturation), a very small amount of aggregate was obtained with $7.2 \%$ enzyme recovery with respect to free enzyme. Most of the enzyme activity was lost during the washing steps. Therefore, it was concluded that a AS addition step is necessary before cross-linking.

CLEAs, produced with 40, 60, 80 and $90 \%$ saturated AS, are shown in Figure 3.4:

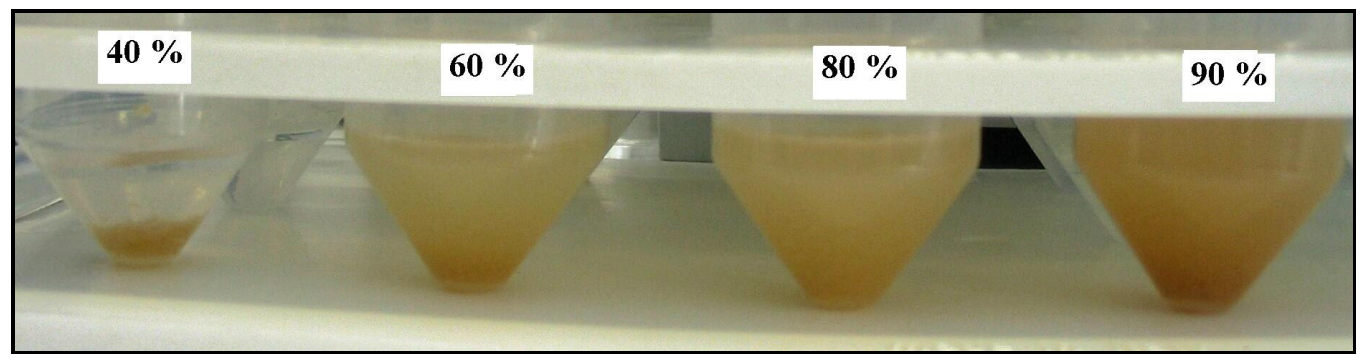

Figure 3.4: Effect of AS concentration on CLEA production. In each case, $1 \mathrm{mg} / \mathrm{ml}$ of pure tyrosinase, $50 \mathrm{mg} / \mathrm{ml}$ of BSA, and $2 \%(\mathrm{v} / \mathrm{v})$ of GA were utilized.

Figure 3.4 shows that as AS concentration increased, quantity of CLEAs increased. The enzyme recoveries corresponding to different AS saturations are given in Figure 3.5. 


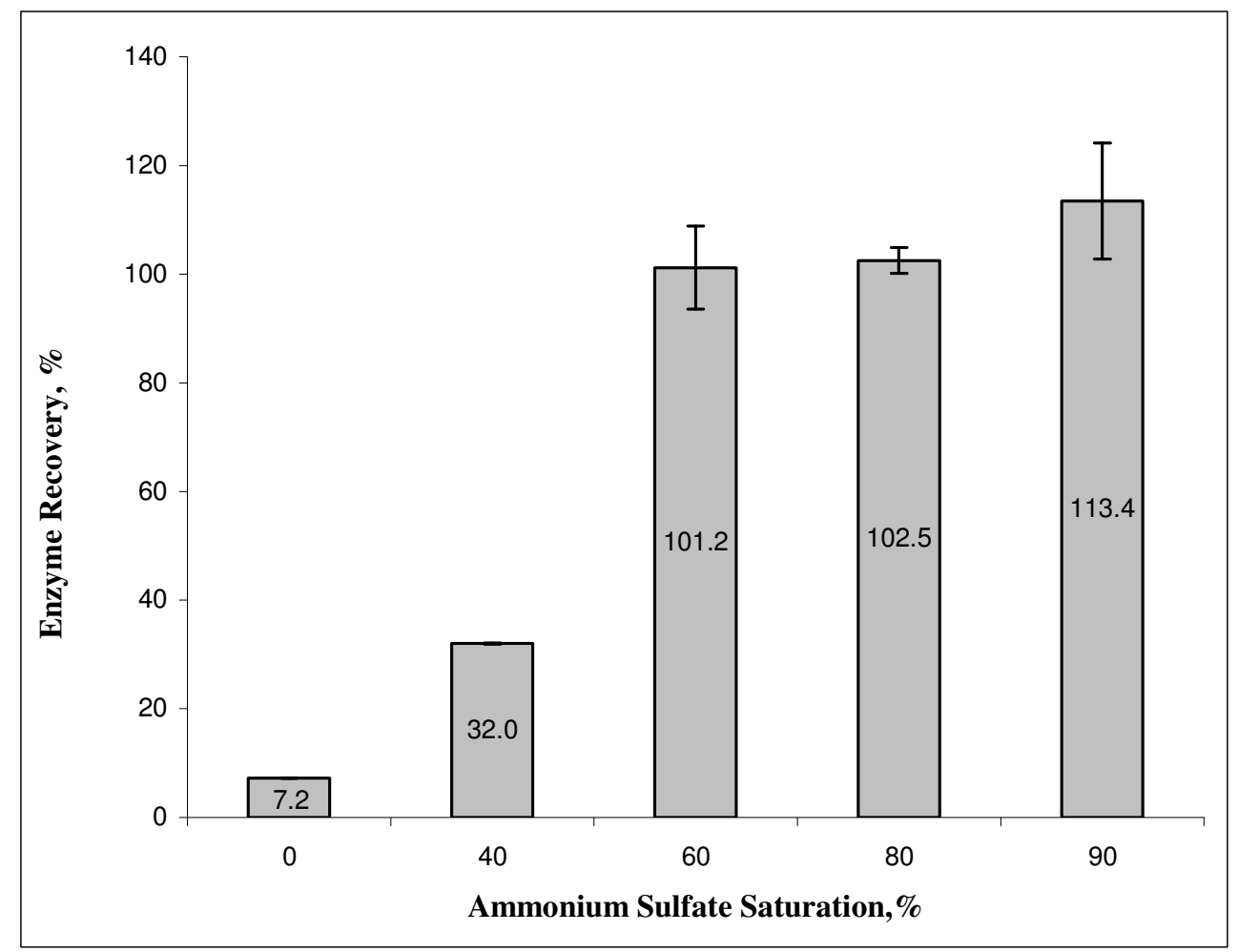

Figure 3.5: Effect of AS concentration on enzyme recovery. In each case, $1 \mathrm{mg} / \mathrm{ml}$ of pure tyrosinase, $50 \mathrm{mg} / \mathrm{ml}$ of BSA, and $2 \%(\mathrm{v} / \mathrm{v})$ of GA were utilized. Enzyme recovery was calculated as (total activity of CLEA)/(total free enzyme activity used for CLEA production) $\times 100$

By using low AS concentrations, only a small percent of tyrosinase could be precipitated. Whereas, at high AS concentrations, most of the proteins precipitate from the solution. When AS was added for precipitation, aggregated proteins were more easily cross-linked to each other by GA than the solvated ones, since in the aggregate form they were closely packed together (Cao et al., 2003). As a result, only a small percent of the native enzyme activity was recovered by using 0 and 40 $\%$ AS saturations. However, at high precipitating agent concentrations, nearly all of 
the free enzyme activity was recovered and at $90 \%$ saturation, a hyperactivation was observed.

Precipitation increases the stability of folded protein conformation, since it decreases the surface area that is in contact with the solvent (Creighton, 1992). Furthermore, precipitation conditions may induce a more active conformation (López-Serrano et al., 2002). These orderly arranged protein aggregates are held together by noncovalent bounding (Cao et al., 2000). By the addition of GA, these aggregates were cross-linked and their conformation was stabilized (Cao et al., 2003). The inter- and intramolecular covalent cross-linking prevents catalyst deactivation (Roy and Abraham, 2004). Tyrosinase can be inactivated by its product o-quinone which undergoes reaction with the free amino groups of the enzyme (Wada et al., 1993). Since tyrosinase was stabilized by producing cross-linked enzyme aggregates, the inactivation by quinones could be lowered when compared to the soluble form. As a result, because of the above mentioned reasons, the produced CLEAs recovered nearly all of the free enzyme activity and also a hyperactivation was observed at high AS concentrations.

In Figure 3.6, scanning electron microscope images of the CLEAs prepared with different AS concentrations are shown. By using $40 \%$ of precipitating agent concentration, a small amount of densely packed particles was formed. By increasing the AS concentration, the amount of the formed particles increased. Moreover, particles prepared with high precipitating agent concentrations had a looser structure with many cavities, which may result in less mass transfer limitations.

In further experiments to reduce the precipitating agent concentration and as a result the production cost, $60 \%$ AS saturation, at which all of the free enzyme was recovered, was utilized. 


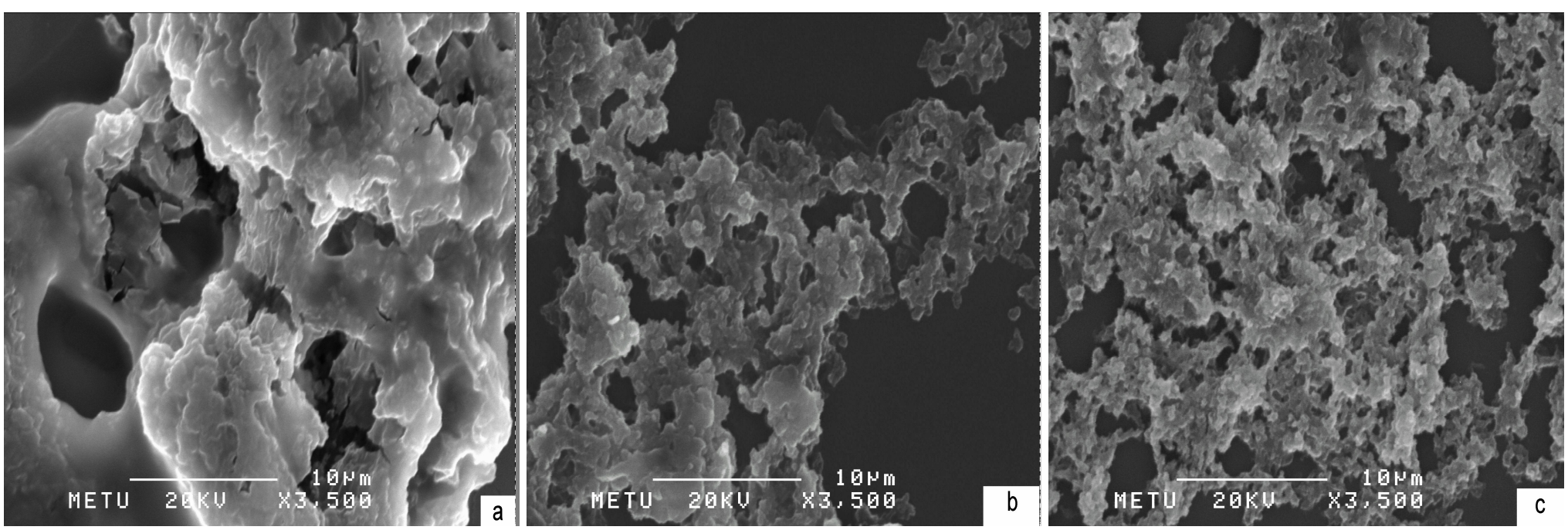

Figure 3.6: Scanning Electron Microscope Images of CLEAs prepared with different AS concentrations (magnification 3500x) a) $40 \% \mathrm{AS}$, b) $60 \% \mathrm{AS}$, c) $80 \% \mathrm{AS}$. In each case: $1 \mathrm{mg} / \mathrm{ml}$ of tyrosinase, $50 \mathrm{mg} / \mathrm{ml}$ of BSA and $2 \%$ (v/v) of GA were used. 


\subsubsection{Effect of the Glutaraldehyde Concentration on CLEA production}

To analyze the effect of the GA concentration on the enzyme recovery, four different concentrations, 1, 2, 3 and $4 \%(\mathrm{v} / \mathrm{v})$ were utilized. The CLEAs produced are shown in Figure 3.7:

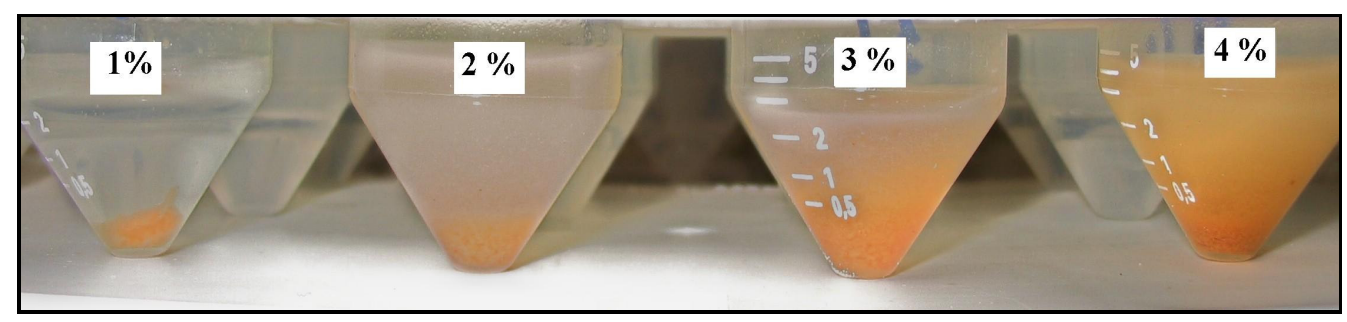

Figure 3.7: The effect of GA concentration on CLEA production. In each case, 1 $\mathrm{mg} / \mathrm{ml}$ of tyrosinase, $50 \mathrm{mg} / \mathrm{ml}$ of BSA and $60 \%$ AS saturation were used.

As GA concentration was increased, the amount of aggregates also increased. At high GA concentration, the extend of cross-linking was high enough to form a firm structure by excluding water molecules to insolubilize the enzyme+BSA complex (Migneault et al., 2004). As a result, in addition to AS precipitation, GA facilitates protein aggregation.

The enzyme recoveries of the CLEAs are shown in Figure 3.8. As seen from this figure, at $2 \%$ of GA concentration, nearly all of the free enzyme activity was recovered. When the concentration was raised to 3 and especially to $4 \%$, hyperactivation was observed. 


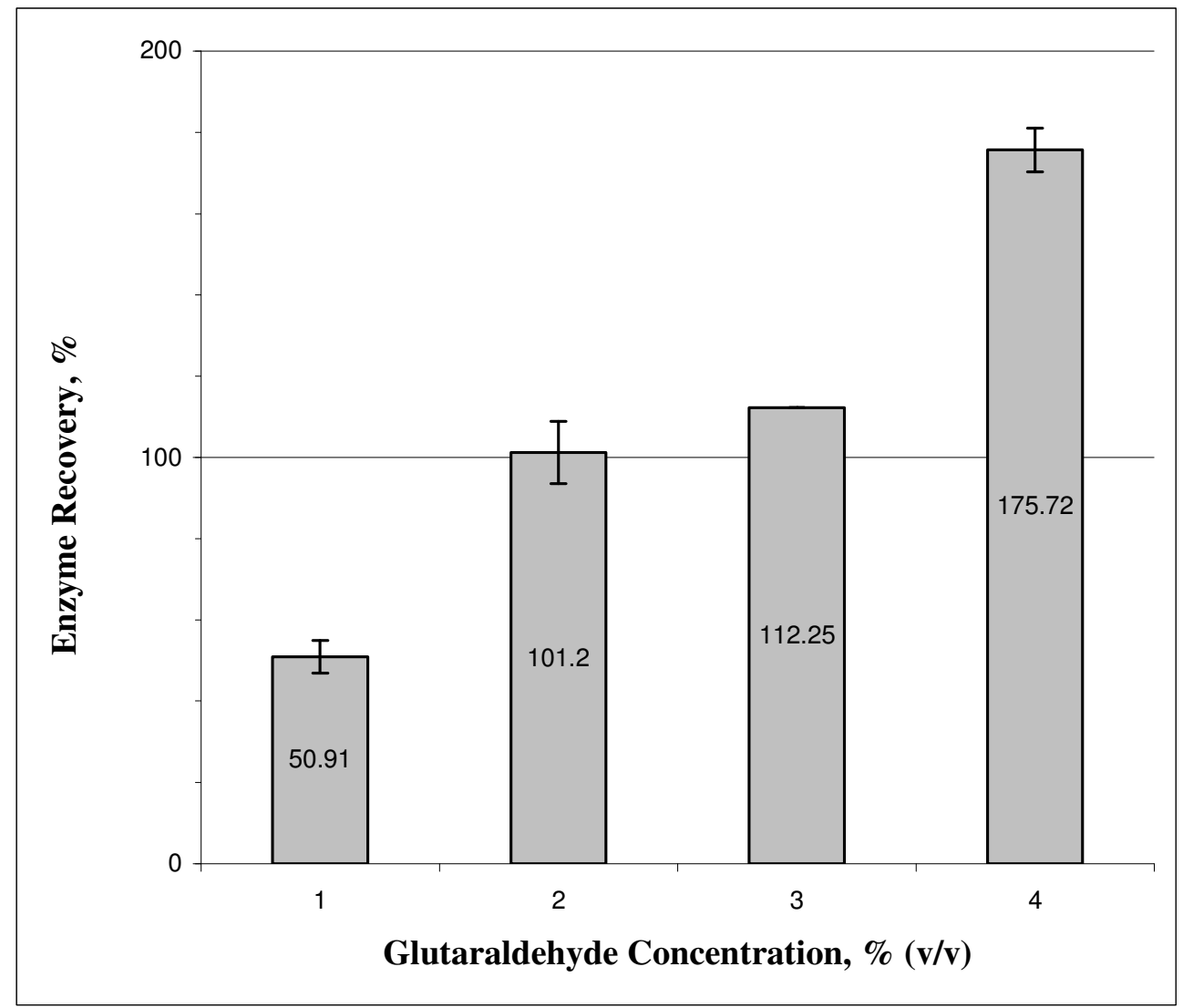

Figure 3.8: The effect of GA concentration on enzyme recovery. In each case $1 \mathrm{mg} / \mathrm{ml}$ of tyrosinase, $50 \mathrm{mg} / \mathrm{ml}$ of BSA and $60 \%$ AS saturation were used. Enzyme recovery was calculated as (total activity of CLEA)/(total free enzyme activity used for CLEA production) $\times 100$

In Figure 3.9, scanning electron microscope images of the CLEAs prepared with different GA concentrations are shown. Cross-linker concentration has a similar effect on the amount and structure of the formed CLEA particles as the AS concentration. By using $1 \%(\mathrm{v} / \mathrm{v})$ cross-linker, a small amount of densely packed particles was formed. As the GA concentration increased, the amount of the formed particles increased. These particles had a looser structure with many cavities. 
Considering about $100 \%$ enzyme recovery, and to minimize GA concentration, following experiments were carried out with $2 \%(\mathrm{v} / \mathrm{v})$ of GA concentration.
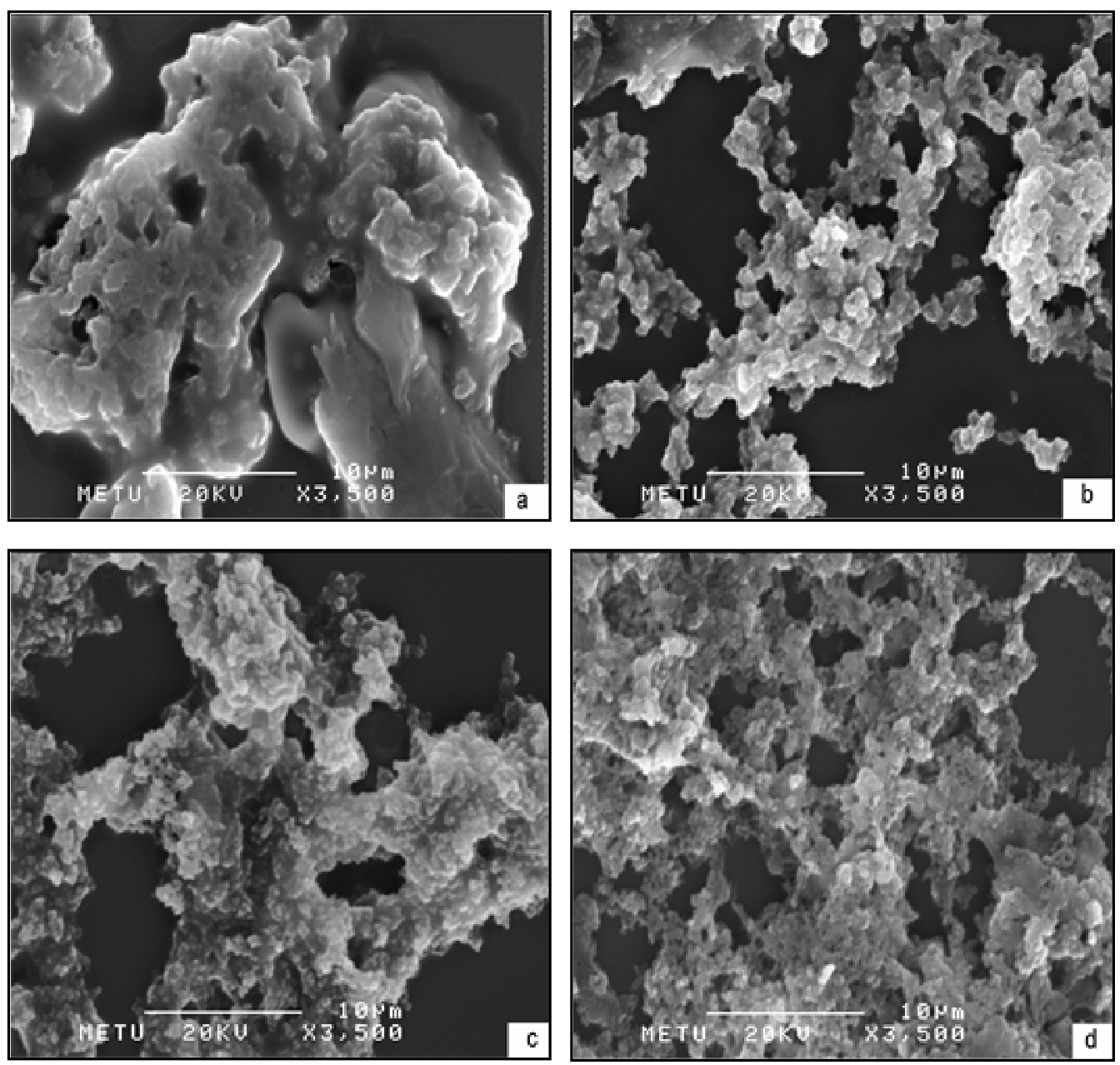

Figure 3.9: Scanning electron microscope Images of CLEAs prepared with different GA concentrations (magnification 3500x).

a) $1 \% \mathrm{GA}$, b) $2 \% \mathrm{GA}$, c) $3 \% \mathrm{GA}$, d) $4 \% \mathrm{GA}$. In each case $1 \mathrm{mg} / \mathrm{ml}$ of tyrosinase, $50 \mathrm{mg} / \mathrm{ml}$ of BSA and $60 \%$ AS saturation were used. 


\subsubsection{Effect of the Particle Size on CLEA Production}

In the formation of cross-linked tyrosinase aggregates, enzymes are packed together in a small volume by inter- and intramolecular cross-links. In addition, filtration, used for the washing period, increases cluster formation. When the CLEA were initially dispersed in the respective buffer, they presented as large clusters. As a result, internal mass transfer limitations were unavoidable in this case. In order to decrease this constraint, particle sizes of the formed aggregates were reduced by mechanical stirring with a magnetic rod. The obtained activity recoveries of the CLEAs and the corresponding microscope images of the particles are shown in Table 3.5 and Figure 3.10, respectively.

Table 3.5: Enzyme recovery of the CLEAs as a function of mixing period. In each case $1 \mathrm{mg} / \mathrm{ml}$ of tyrosinase, $50 \mathrm{mg} / \mathrm{ml}$ of BSA, $60 \%$ AS saturation, and $2 \%(\mathrm{v} / \mathrm{v})$ GA were used. Enzyme recovery was calculated as (total activity of CLEA)/(total free enzyme activity used for CLEA production) $\times 100$

\begin{tabular}{|c|c|c|c|c|}
\hline & \multicolumn{4}{|c|}{ Mixing time (min) } \\
\hline & 5 & 25 & 85 & 105 \\
\hline $\begin{array}{c}\text { Enzyme } \\
\text { recovery,\% }\end{array}$ & & & & \\
& $63 \pm 3$ & $65 \pm 2$ & $101 \pm 8$ & $88 \pm 11$ \\
\hline
\end{tabular}

After 5 minutes of size reduction, CLEA particles were still densely packed and very large $(80-100 \mu \mathrm{m})$. As a result, due to a significant mass transfer limitation, enzyme recovery was observed as low. After 85 minutes of mixing, the size of the particles were considerably reduced $(1-10 \mu \mathrm{m})$, and the amount of the cavities within the particles increased. At this time, since the particles were finely dispersed in the solution, mass transfer limitation was not significant and enzyme recovery was 100 
$\%$. Further mixing of the CLEA suspension resulted in the loss of the activity probably due to shear effects generated by agitation.
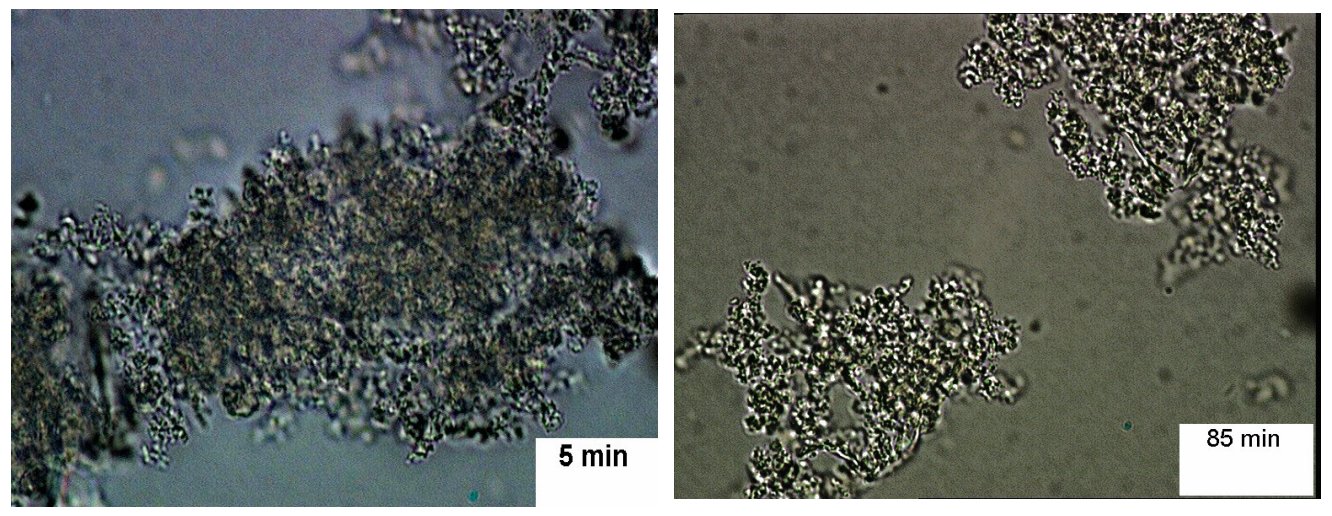

Figure 3.10: Microscope images of the CLEA particles after certain mixing times (magnification 1000x)

\subsubsection{Effect of Simultaneous and Consecutive Addition of Ammonium Sulfate and Glutaraldehyde on CLEA production}

In this part of the study, two samples were prepared. For the first sample, initially saturated AS was added to the enzyme solution. After 5 min of mixing, GA was added. For the second sample, previously mixed AS and GA were added to the enzyme solution.

As seen from Table 3.6, the order of the addition of the precipitating and cross-linking agents had no significant effect on the activities of the CLEAs. 
Table 3.6: Effect of the order of AS and GA addition. In each case, $1 \mathrm{mg} / \mathrm{ml}$ of tyrosinase, $50 \mathrm{mg} / \mathrm{ml}$ of BSA, $60 \%$ AS saturation, and $2 \%(\mathrm{v} / \mathrm{v})$ GA were used.

\begin{tabular}{|c|c|c|}
\hline & $\begin{array}{c}\text { Addition AS } \\
\text { and GA } \\
\text { simultaneously }\end{array}$ & $\begin{array}{c}\text { Addition AS } \\
\text { and GA } \\
\text { consecutively }\end{array}$ \\
\hline $\begin{array}{c}\text { Tyrosinase } \\
\text { activity (U) }\end{array}$ & $31.2 \pm 1.0$ & $31.3 \pm 1.8$ \\
\hline
\end{tabular}

\subsubsection{Effect of Cross-linking Conditions on CLEA Production}

Since cross-linking is a chemical reaction, the rate depends on temperature. This reaction can be performed at low temperatures $\left(4{ }^{\circ} \mathrm{C}\right)$ for labile proteins, however, in this case, cross-linking may require longer time periods (Broun, 1976). In this part of the experiment, the optimum combination of the cross-linking period and temperature was tried to be determined. The investigated cross-linking time and temperatures and corresponding activities are illustrated in Figure 3.11.

After 3 hours of cross-linking reaction, higher activity was obtained when the reaction was conducted at room temperature rather than at $4{ }^{\circ} \mathrm{C}$. When the crosslinking was performed at $4{ }^{\circ} \mathrm{C}$ for overnight, nearly the same activity of room temperature, 3 hours case was obtained. As a result, in the following experiments, the cross-linking reaction was performed for 3 hours at room temperature. 


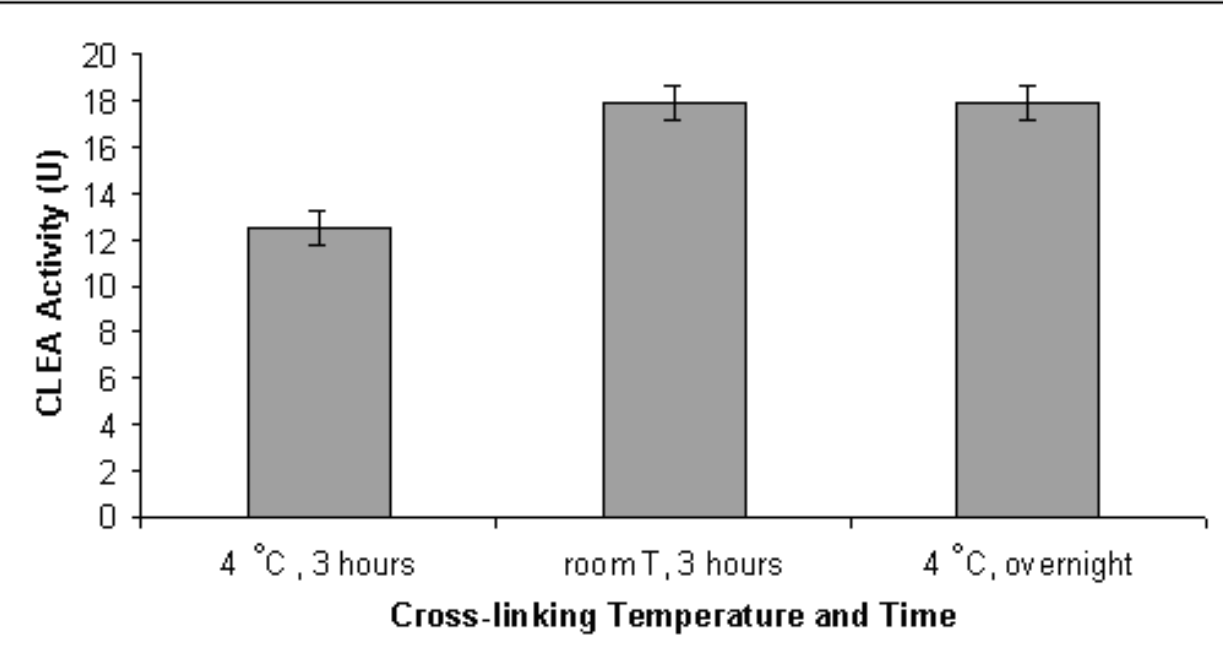

Figure 3.11: The effect of cross-linking conditions on CLEA production. In each case $1 \mathrm{mg} / \mathrm{ml}$ of tyrosinase, $50 \mathrm{mg} / \mathrm{ml}$ of BSA, $60 \%$ saturation AS, and $2 \%(\mathrm{v} / \mathrm{v}$ ) GA were used.

In summary, the optimum conditions for CLEA production from pure tyrosinase with nearly $100 \%$ enzyme recovery are shown in Table 3.7.

Table 3.7: Optimum conditions for CLEA production from pure tyrosinase. The enzyme recovery was $101.2 \pm 7.64 \%$.

\begin{tabular}{|l|l|}
\hline Enzyme solution & $\begin{array}{l}1 \mathrm{mg} / \mathrm{ml} \text { of tyrosinase and } 50 \mathrm{mg} / \mathrm{ml} \text { of BSA } \\
\text { in } 0.1 \mathrm{M} \mathrm{pH} 7.0 \text { sodium phosphate buffer }\end{array}$ \\
\hline AS concentration & $60 \%$ saturation \\
\hline GA concentration & $2 \%(\mathrm{v} / \mathrm{v})$ \\
\hline Cross-linking reaction & for 3 hours at room temperature \\
\hline $\begin{array}{l}\text { Pre-treatment before washing } \\
\text { of CLEAs }\end{array}$ & Storage in L-lysine solution for overnight \\
\hline Washing method & Filtration \\
\hline Particle size reduction & by mechanical stirring \\
\hline
\end{tabular}




\subsection{Characterization of CLEAs Prepared from Pure Tyrosinase}

After the determination of the optimum conditions for CLEA production from pure tyrosinase, the characterization of CLEAs was conducted. In this part, the temperature dependence of the reaction, and thermal and storage stabilities of CLEAs were determined and they were compared with those of the free enzyme.

\subsubsection{Temperature Dependence of Free and Cross-linked Tyrosinases}

In order to determine the optimum temperature values of the free and crosslinked tyrosinases, enzyme activities were measured at different temperatures ranging from $25-35^{\circ} \mathrm{C}$. The results are given in Figure 3.12 .

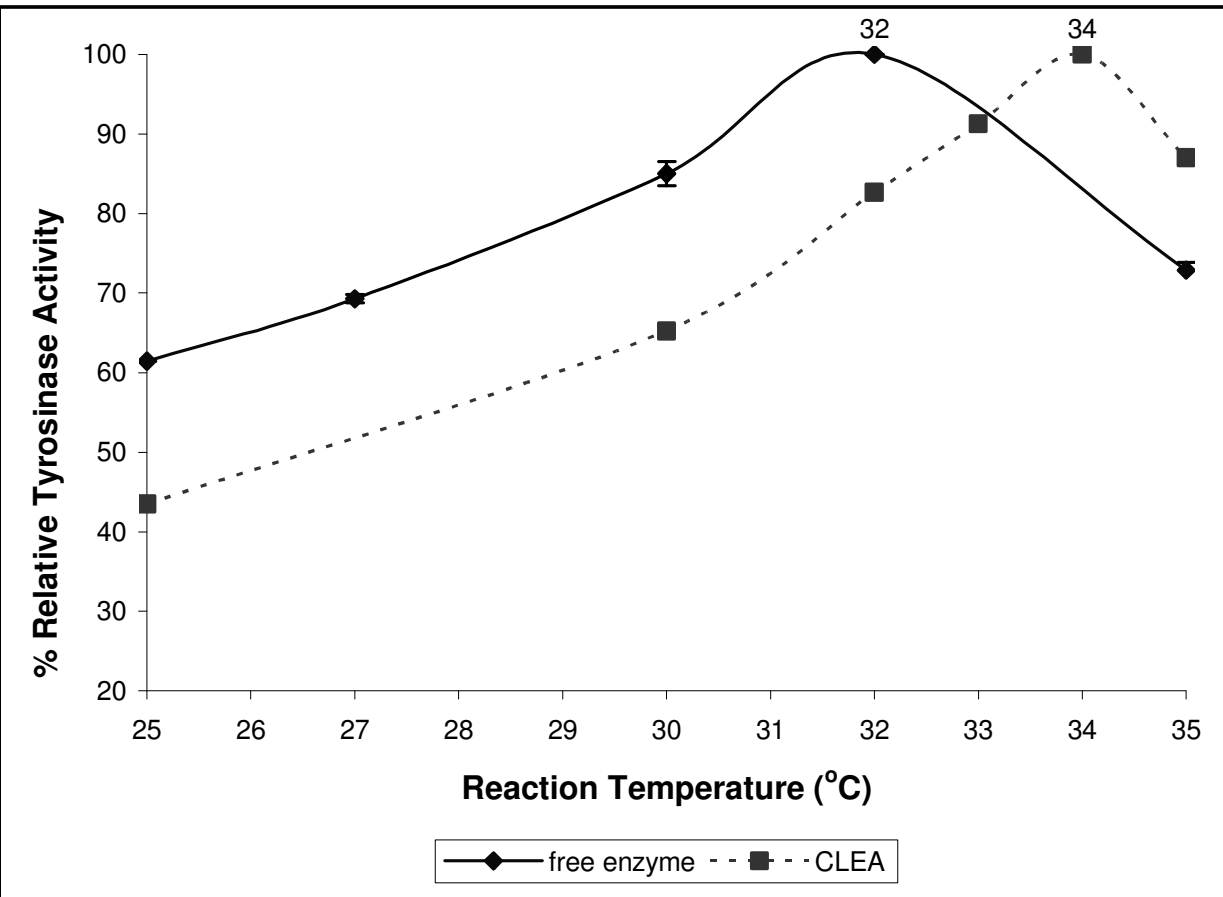

Figure 3.12: Effect of temperature on the activities of free and cross-linked tyrosinases. Results were given in relative form with the highest value being assigned as $100 \%$ activity. 
The temperature optima for the free and cross-linked tyrosinases were found as $32{ }^{\circ} \mathrm{C}$ and $34{ }^{\circ} \mathrm{C}$, respectively. This shift in the optimum temperature could be explained by the reactions taking place in the preparation of CLEAs. During immobilization, covalent bonds were formed between proteins by GA molecules. This formation might decrease the conformational flexibility of the enzyme molecule to bind to the substrate. As a result, higher temperature was needed to attain the appropriate conformation.

Optimum temperature values of the free and immobilized mushroom tyrosinases from literature were given in Table 3.8.

Table 3.8: Optimum temperatures of the free and immobilized tyrosinases obtained from literature

\begin{tabular}{|c|c|c|c|c|}
\hline Reference & $\begin{array}{c}\text { Immobilization } \\
\text { type }\end{array}$ & Substrate & $\begin{array}{c}\text { Free } \\
\text { tyrosinase } \\
\text { optimum } \\
\text { temperature } \\
\left({ }^{\circ} \mathrm{C}\right)\end{array}$ & $\begin{array}{c}\text { Immobilized } \\
\text { tyrosinase } \\
\text { optimum } \\
\text { temperature } \\
\left({ }^{\circ} \mathrm{C}\right)\end{array}$ \\
\hline $\begin{array}{l}\text { Khan et } \\
\text { al.(2005) }\end{array}$ & $\begin{array}{c}\text { Tyrosinase was } \\
\text { immobilized on IgG- } \\
\text { Seralose 4B }\end{array}$ & Phenol & 35 & $30 \& 35$ \\
\hline $\begin{array}{l}\text { Yahşi et } \\
\text { al.(2005) }\end{array}$ & $\begin{array}{l}\text { Tyrosinase was } \\
\text { immobilized to Ca- } \\
\text { alginate gel beads and } \\
\text { poly(acrylamide-co- } \\
\text { acrylic acid) hydrogels }\end{array}$ & Tyrosine & 30 & 35 \\
\hline $\begin{array}{l}\text { Arica } \\
(2000)\end{array}$ & $\begin{array}{c}\text { Tyrosinase was } \\
\text { immobilized on } \\
\text { carboxymethylcellulose } \\
\text { beads }\end{array}$ & $\begin{array}{c}\text { L- } \\
\text { tyrosine }\end{array}$ & 40 & 45 \\
\hline
\end{tabular}


As observed from Table 3.8, the experimental results for optimum temperature of the free tyrosinase and shift in the optimum temperature after immobilization were comparable with the results obtained from literature.

\subsubsection{Activation Energies of Oxidation of Catechol by Free and Cross-linked Tyrosinases}

Activation energies of oxidation of catechol by the free enzyme and CLEA were determined in the temperature range of $25-35{ }^{\circ} \mathrm{C}$. The activation energies were calculated by using Arrhenius equation,

$$
\mathrm{k}=\mathrm{k}_{\mathrm{o}} \mathrm{e}^{-\mathrm{E} / \mathrm{RT}}
$$

where $\mathrm{k}$ is the reaction rate constant, $\mathrm{k}_{\mathrm{o}}$ is the frequency factor, $\mathrm{E}$ is the activation energy, $\mathrm{R}$ is the gas constant and $\mathrm{T}$ is the absolute temperature (Levenspiel, 1999).

Arrhenius plots were constructed by using the initial reaction rates obtained in the previous experiments and shown in Figure 3.13 for the free and cross-linked tyrosinases.

From the slopes of the Arrhenius plots, the activation energies for the free and cross-linked tyrosinases were calculated as $12.5 \mathrm{kcal} / \mathrm{mol}$ and $16.9 \mathrm{kcal} / \mathrm{mol}$, respectively. This was an expected result, since, due to immobilization the conformational stability of the enzyme has reduced. As a result, higher activation energy was required to attain the appropriate enzyme conformation to bind to the substrate. 


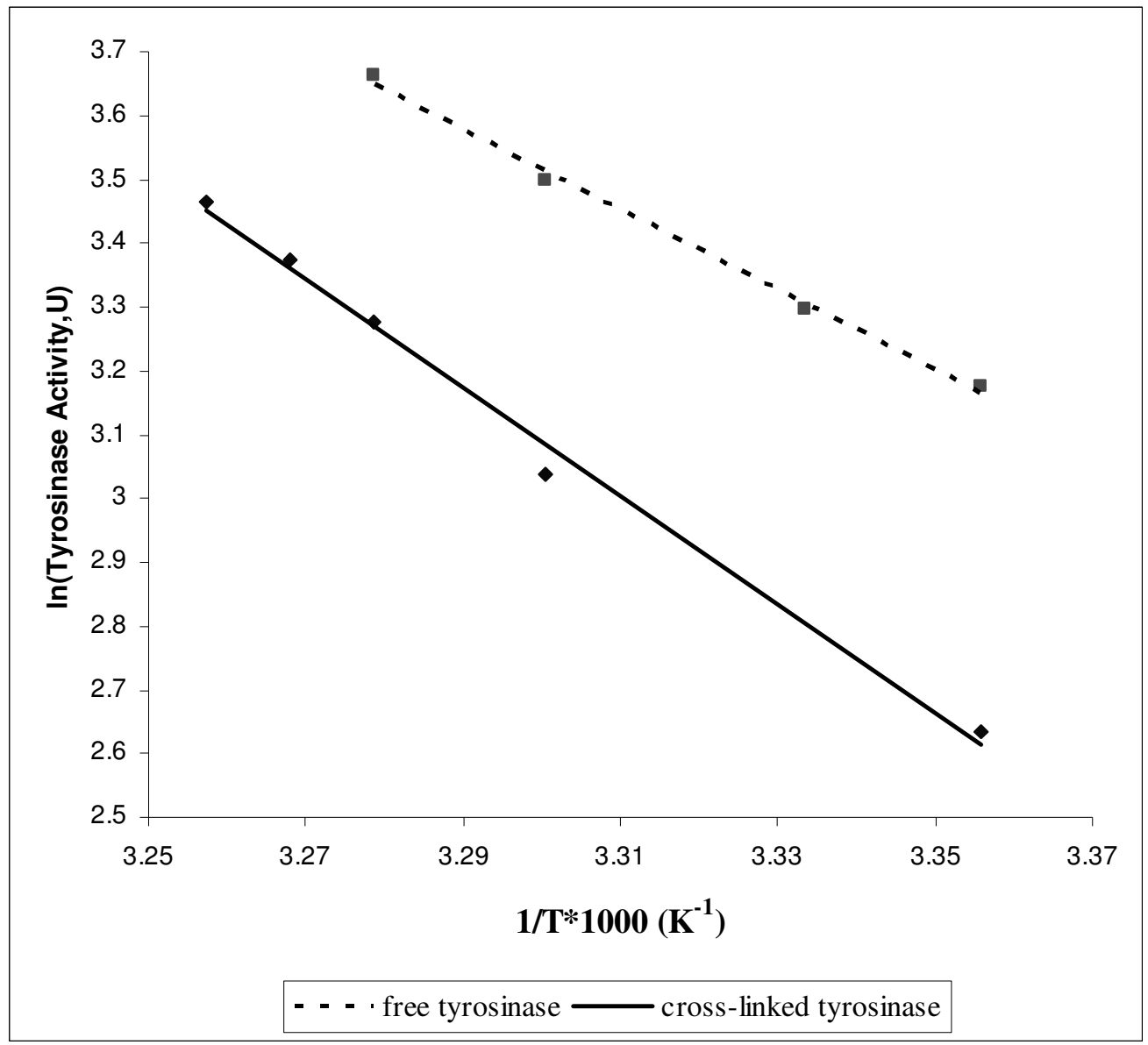

Figure 3.13: Arrhenius plots for the oxidation of catechol by the free and crosslinked tyrosinases. The slope gives $-\mathrm{E}_{\mathrm{a}} / \mathrm{R}$ ratio.

\subsubsection{Thermal Deactivation of Free and Cross-linked Tyrosinases}

Thermal stability experiments for both the free enzyme and CLEAs were conducted by incubating the enzyme samples at 45,55 and $65{ }^{\circ} \mathrm{C}$ for various time intervals. At the end of the required time intervals, the remaining activities of these samples were measured. The obtained results are given in Figure 3.14 (a) and (b) for the free enzyme and CLEA, respectively. 

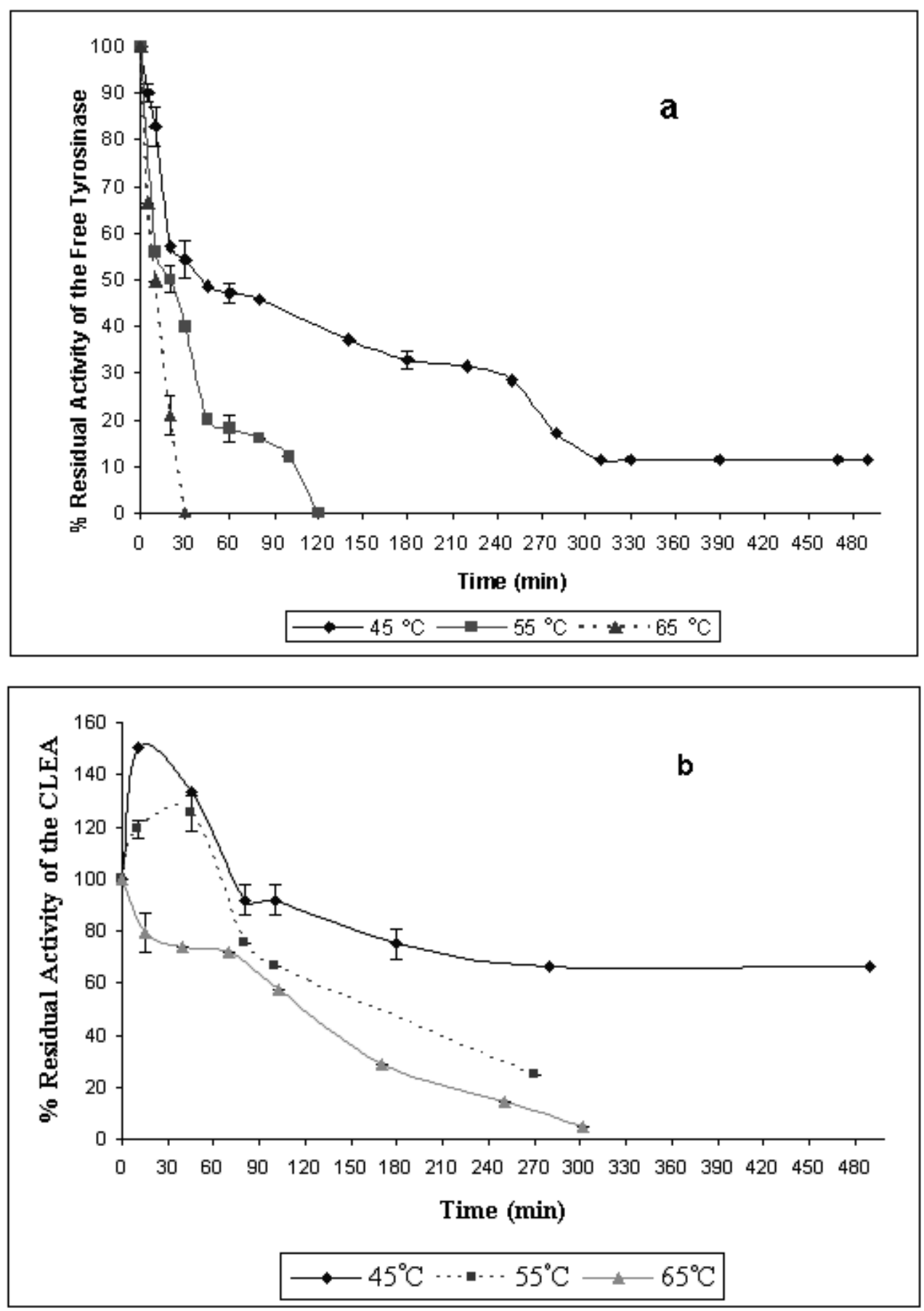

Figure 3.14: Thermal deactivation of tyrosinase at different temperatures. Residual activities were found at the end of indicated preincubation times at the stated temperatures, followed by the activity assay at $35^{\circ} \mathrm{C}$. (a): free enzyme (b): CLEA 
A comparison of thermal stabilities of free enzyme and CLEA is given in Table 3.9. A hyperactivation of the CLEA was observed up to 10 minutes incubation at $45{ }^{\circ} \mathrm{C}$. Then, activity decreased and after 8 hours, cross-linked tyrosinase aggregates still retained $70 \%$ of their initial activities. However, the same amount of activity loss of the free enzyme occurred in about 15 minutes at the same temperature. At $55{ }^{\circ} \mathrm{C}$, a hyperactivation of CLEA was again observed up to 45 minutes. After 120 minutes, the residual activity reduced to $60 \%$. At the end of the same incubation time, all of the free enzyme activity was lost. At $65{ }^{\circ} \mathrm{C}$, after 30 minutes of incubation, free and cross-linked tyrosinases retained $0 \%$ and $75 \%$ of their initial activities, respectively.

These results suggest that, thermostability of tyrosinase increased considerably after the formation of the cross-linked enzyme aggregates. This increase in the stability can be due to inter- and intramolecular covalent cross-links that prevent conformational changes (such as unfolding), as a result, catalyst deactivation as explained by Migneault et al., 2004.

Table 3.9: Thermal deactivation of free enzyme and CLEAs at different temperatures. Residual activities were found at the end of the indicated preincubation times at the stated temperatures, followed by the activity assay at $35^{\circ} \mathrm{C}$.

\begin{tabular}{|c|c|c|c|c|c|c|}
\hline $\begin{array}{c}\text { Incubation } \\
\text { Temperature } \\
\left({ }^{\mathbf{0}} \text { C) }\right.\end{array}$ & \multicolumn{2}{|c|}{45} & \multicolumn{2}{c|}{55} & \multicolumn{2}{c|}{} \\
\hline & CLEA & $\begin{array}{c}\text { Free } \\
\text { Tyrosinase }\end{array}$ & CLEA & $\begin{array}{c}\text { Free } \\
\text { Tyrosinase }\end{array}$ & CLEA & $\begin{array}{c}\text { Free } \\
\text { Tyrosinase }\end{array}$ \\
\hline $\begin{array}{c}\text { Incubation } \\
\text { Time (min) }\end{array}$ & 480 & 15 & 120 & 120 & 30 & 30 \\
\hline $\begin{array}{c}\text { \% Residual } \\
\text { Activity }\end{array}$ & 70 & 70 & 60 & 0 & 75 & 0 \\
\hline
\end{tabular}




\subsubsection{Storage Stability of the CLEAs Prepared from Pure Tyrosinase}

To test the stability of cross-linked tyrosinase aggregates, samples were both stored at room temperature and at $4{ }^{\circ} \mathrm{C}$ and their activity values were measured at certain time intervals. The results are shown Figure 3.15.

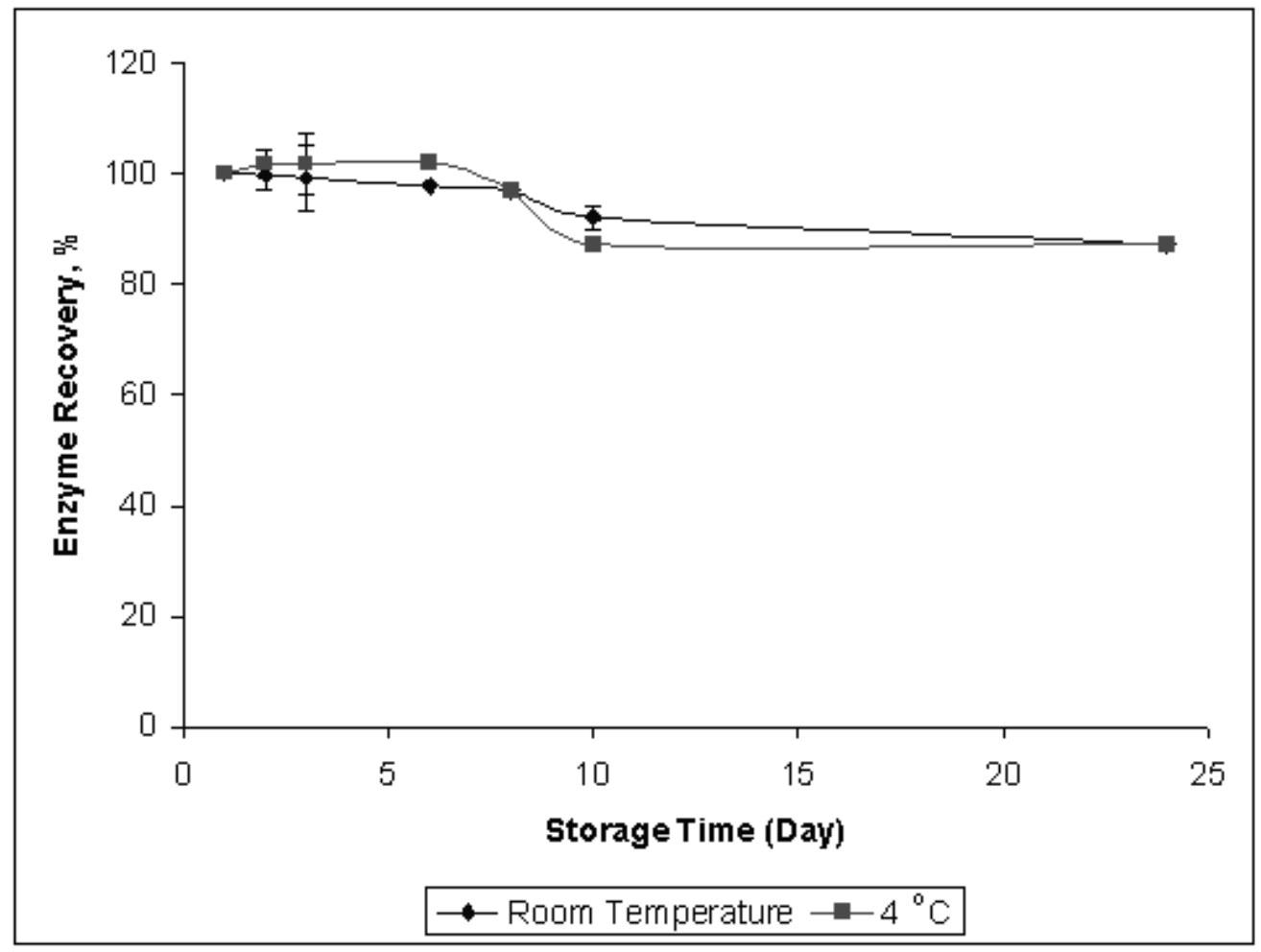

Figure 3.15: Storage stability of the CLEAs stored in two different temperatures.

The obtained data was analyzed with two-way ANOVA and the detailed results of this analysis are given in Appendix E. 
According to Figure 3.15 and to the two-way ANOVA (P value: $0.56>0.05$ ), storage temperature had no effect on the CLEA activity. CLEAs still retained $87 \%$ of their initial activities after 24 days of storage.

\subsection{Preparation of CLEAs from Crude Mushroom Extract}

During the preliminary experiments, CLEAs were prepared from crude mushroom tyrosinase with a maximum enzyme recovery of $65 \%$ with respect to the free enzyme. In order to increase this recovery, optimization studies were conducted with pure tyrosinase and at the end of these studies, CLEAs were produced which recovered nearly all of the free enzyme activity.

In this part of the study, it was aimed to use the optimum conditions to prepare CLEAs again from crude mushroom extract. Since this extract included many other proteins in addition to the desired enzyme, no BSA was added. Moreover, in this part, two GA concentrations were used; 0.1 and $2 \%(\mathrm{v} / \mathrm{v})$. By using the former concentration, (mg protein in the enzyme solution)/(ml of GA added) ratio was made same with the CLEA prepared from pure tyrosinase, and the latter concentration was the obtained value during the optimization study.

The formed CLEAs and enzyme recoveries are shown in Figure 3.16 and in Table 3.10, respectively.

As seen from Figure 3.16, by using $0.1 \%$ (v/v) GA, a small amount of CLEAs could be obtained from crude mushroom extract. 


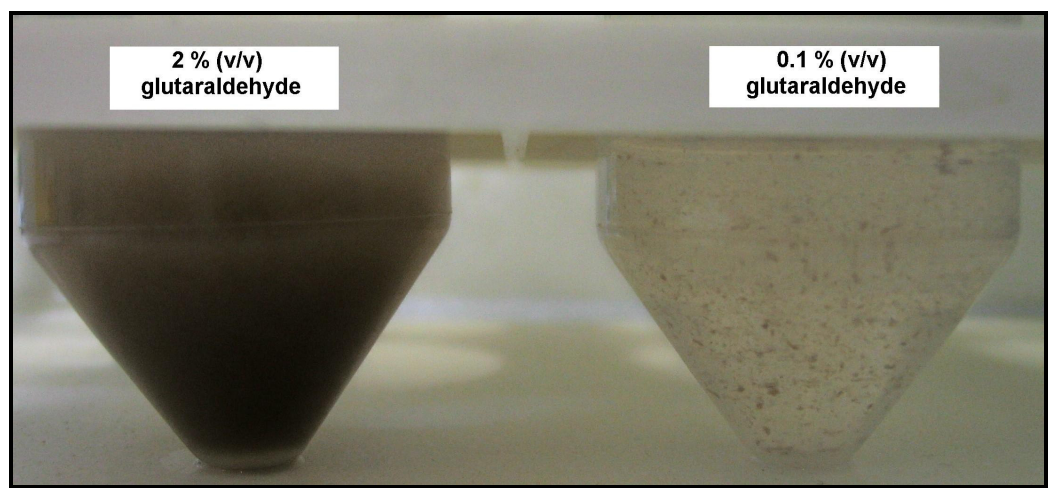

Figure 3.16: The effect of GA concentration on CLEA production from crude mushroom extract. In each case, $60 \%$ AS saturation was used.

Table 3.10: Enzyme recoveries of CLEAs prepared from crude mushroom extract

\begin{tabular}{|c|c|c|}
\hline $\begin{array}{c}\text { GA Concentration, \% } \\
(\mathrm{v} / \mathrm{v})\end{array}$ & 0.1 & 2 \\
\hline Enzyme Recovery, \% & $25 \pm 3$ & $104 \pm 0$ \\
\hline
\end{tabular}

As observed from Table 3.10, by using $0.1 \%$ GA concentration only $25 \%$ of the free enzyme activity was recovered in the CLEA. This concentration of GA was not enough to cross-link most of the enzymes, since during the washing steps, a high amount of the enzyme activity was observed in the filtrate. On the other hand, by using $2 \%$ GA concentration, all of the free enzyme activity was recovered in CLEAs. 
In Table 3.11, the preparation conditions and enzyme recoveries of the CLEAs (produced from crude mushroom extract) before and after the optimization studies are shown.

Although both of the CLEA's were prepared with the same AS and GA concentrations, due to some different conditions used for the CLEA production, such as cross-linking temperature and period, lysine treatment, type of solid-liquid separation method, and particle size reduction, different enzyme recoveries were obtained.

Initially, the cross-linking reaction of CLEAs during the preliminary experiments was performed at $4{ }^{\circ} \mathrm{C}$ for 2.5 hours. As observed from Section 3.2.7, this cross-linking period at $4{ }^{\circ} \mathrm{C}$ might not be enough to complete the cross-linking reaction. Secondly, in the optimization studies, the formed CLEAs were stored in a 0.1 M L-lysine solution, in order that this amino acid reacts with excess GA present. Moreover, in the preliminary experiments, centrifugation was used during the washing steps of the CLEAs. However, as explained before, this method had some difficulties in the sedimentation and recovery of the aggregates. Finally, after CLEA's were formed in the preliminary experiments, they were stored as a suspension without mixing to reduce the particle size. A little amount of size reduction occurred by itself, however this was not as efficient as mechanical stirring. Therefore, mass transfer limitations were significant.

After the application of the conditions, obtained during the optimization studies, highly active CLEAs from crude mushroom extracts were prepared. Then these CLEAs were analyzed in terms of storage stability. As seen from Figure 3.17, CLEAs still retained $95 \%$ of its initial activity after 9 days of storage at $4{ }^{\circ} \mathrm{C}$. 
Table 3.11: CLEAs prepared from crude mushroom extract before and after the optimization studies

\begin{tabular}{|c|c|c|}
\hline & \multicolumn{2}{|c|}{$\begin{array}{l}\text { CLEAs prepared from } \\
\text { crude mushroom extract }\end{array}$} \\
\hline & $\begin{array}{c}\text { In preliminary } \\
\text { experiments } \\
\text { (Before optimization } \\
\text { studies) }\end{array}$ & $\begin{array}{c}\text { After optimization } \\
\text { studies }\end{array}$ \\
\hline Enzyme solution & $\begin{array}{l}\text { Crude mushroom extract } \\
\qquad(\approx 43 \mathrm{U})\end{array}$ & $\begin{array}{l}\text { Crude mushroom extract } \\
\qquad(\approx 43 \mathrm{U})\end{array}$ \\
\hline AS concentration & $60 \%$ saturation & $60 \%$ saturation \\
\hline GA concentration & $2 \%(\mathrm{v} / \mathrm{v})$ & $2 \%(\mathrm{v} / \mathrm{v})$ \\
\hline $\begin{array}{l}\text { Cross-linking } \\
\text { Temperature }\end{array}$ & $4^{\circ} \mathrm{C}$ & $\begin{array}{c}\text { Room } \\
\text { temperature }\end{array}$ \\
\hline $\begin{array}{l}\text { Cross-linking time, } \\
\text { hours }\end{array}$ & 2.5 & 3 \\
\hline $\begin{array}{c}\text { Pre-treatment before } \\
\text { washing } \\
\text { of CLEAs }\end{array}$ & - & $\begin{array}{l}\text { CLEAs were stored in L- } \\
\text { lysine solution for } \\
\text { overnight }\end{array}$ \\
\hline Washing & Centrifugation & Filtration \\
\hline Particle size reduction & No mechanical mixing & By mechanical stirring \\
\hline Enzyme recovery, \% & 65 & 104 \\
\hline
\end{tabular}




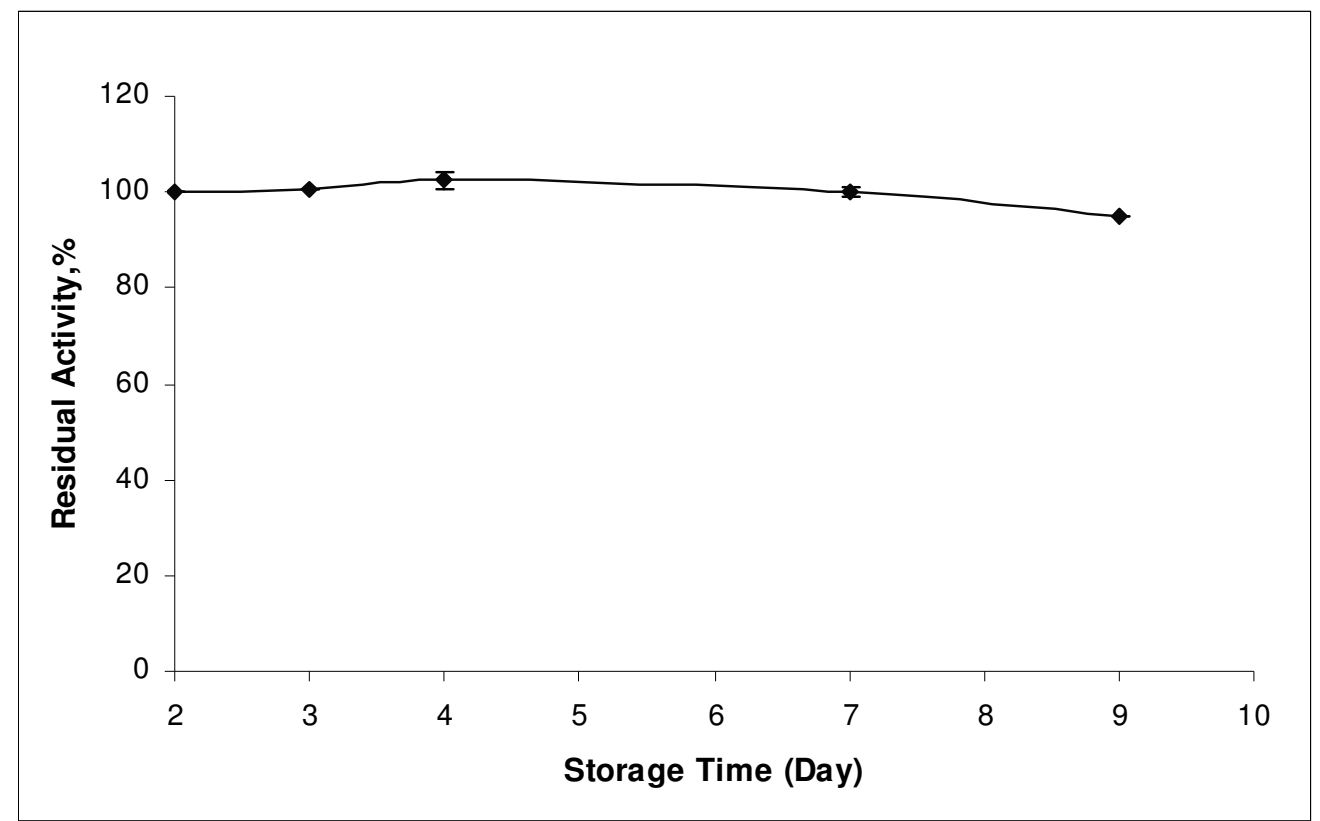

Figure 3.17: Storage stability of CLEAs prepared from crude mushroom extract

In summary, stable cross-linked tyrosinase aggregates were successfully produced from crude mushroom extract without any purification step. 


\section{CHAPTER 4}

\section{CONCLUSIONS}

The aim of this study was to prepare and characterize cross-linked enzyme aggregates (CLEAs) of tyrosinase prepared from crude mushroom extract. These immobilized enzymes are going to be used in different areas such as in biosensor applications and in biotransformation reactions.

The optimization of CLEA production was performed by using pure tyrosinase. In the optimization studies, the effects of protein addition, AS and GA concentrations, CLEA particle size, order of the AS and GA addition, and crosslinking temperature and period on the enzyme recovery of CLEAs were investigated.

By increasing the protein concentration of the tyrosinase solution $(1 \mathrm{mg} / \mathrm{ml})$ with a lysine rich protein, BSA $(50 \mathrm{mg} / \mathrm{ml})$, CLEA enzyme recovery increased.

By increasing the AS and GA concentrations, the amount of the formed aggregates increased, the structure of CLEAs loosened and their activities increased. The optimum concentrations of AS and GA were found as $60 \%$ saturation and $2 \%$ $(\mathrm{v} / \mathrm{v})$, respectively.

By reducing the particle sizes of CLEAs by mechanical stirring, internal mass transfer limitations were considerably reduced. As a result, the observed CLEA enzyme recoveries were increased.

The order of cross-linking and precipitating agent addition to the enzyme solution did not cause any significant difference in the CLEA activities. 
Furthermore, to complete the cross-linking reaction, more time was needed if the reaction was performed at $4{ }^{\circ} \mathrm{C}$ rather than at room temperature. The optimum cross-linking reaction temperature and period were determined as room temperature and 3 hours, respectively.

CLEAs, prepared both from the pure and crude tyrosinases under the optimum conditions, had nearly $100 \%$ enzyme recovery. CLEAs of crude tyrosinases still retained $72 \%$ of their maximum activity after an 8 month of storage at $4{ }^{\circ} \mathrm{C}$.

In the characterization studies of CLEAs prepared from pure tyrosinase, temperature dependence of the reaction and thermal and storage stabilities of the aggregates were analyzed. The optimum temperature and activation energy of catechol oxidation for both the CLEA and free enzyme were found as $34{ }^{\circ} \mathrm{C}$, and $16.9 \mathrm{kcal} / \mathrm{mol}$ and $32{ }^{\circ} \mathrm{C}$ and $12.5 \mathrm{kcal} / \mathrm{mol}$, respectively. Moreover, by preparing CLEAs, the thermostability of tyrosinase was significantly increased. CLEA particles had nearly the same stability during the storage at $4{ }^{\circ} \mathrm{C}$ and at room temperature. In both of the conditions, CLEAs retained $87 \%$ of their initial activities after 24 days of storage.

In conclusion, in this study, CLEAs having high thermal and storage stabilities were prepared with $100 \%$ enzyme recovery from crude mushroom extract.

For the further studies, initially the optimum $\mathrm{pH}, \mathrm{pH}$ stability and kinetic parameters of CLEAs prepared from pure tyrosinase will be determined. Then, the characterization studies will be applied to CLEAs prepared from crude mushroom extract to check whether the impurities affect the properties of CLEAs. Finally, CLEAs of crude tyrosinase will be used in a biosensor application or in a biotransformation reaction. 


\section{REFERENCES}

Abdullah, J., Ahmad, M., Karuppiah, N. Heng, L. Y., Sidek, H. (2006). Immobilization of tyrosinase in chitosan film for an optical detection of phenol. Sensors and Actuators B, 114, 604-609.

Arıca, M. Y. (2000). Immobilization of polyphenol oxidase on carboxymethylcellulose hydrogel beads: preparation and characterization. Polymer International, 49, 775-781.

Arıca, M. Y., Bayramoğlu, G. (2004). Reversible immobilization of tyrosinase onto polyethyleneimine-grafted and $\mathrm{Cu}$ (II) chelated poly (HEMA-coGMA) reactive membranes. Journal of Molecular Catalysis B: Enzymatic, 27, 255265.

Birnbaum, S. (1988). Immobilized Macromolecules: Application potentials. London: Springer Verlag.

Boshoff, A., Edwards, W., Leukes, W. D., Rose, P. D., Burton, S. G. (1998). Immobilisation of polyphenol oxidase on nylon and polyethersulphone membranes: Effect on product formation. Desalination, 115, 307-312.

Bradford, M. M. (1976). A Rapid and sensitive method for the quantitation of microgram quantities of protein utilizing the principle of protein-dye binding. Analytical Biochemistry, 72, 248-254.

Broun, G. B. (1976). Chemically aggregated enzymes. In: Methods in Enzymology (pp. 263-280). Vol.44 (Mosbach, K., Ed.). New York: Academic Press. 
Bullock, G. R. (1984). The current-status of fixation for electron microscopy: a review. Journal of Microscopy, 133 (1), 1-15.

Cao, L., van Langen, L., Sheldon, R. A. (2003). Immobilised enzymes: carrier-bound or carrier-free? Current Opinion in Biotechnology, 14, 387-394.

Cao, L., van Rantwijk, F., Sheldon, R. A. (2000). Cross-linked enzyme aggregates: A simple and effective method for the immobilization of penicillin acylase. Organic Letters, 2 (10), 1361-1364.

Creighton, T. E. (1992). Proteins: Structures and Molecular Properties. New York: W.H. Freeman\& Co Ltd.

Edwards, W., Leukes, W. D., Rose, P. D., Burton, S. G. (1999). Immobilization of polyphenol oxidase on chitosan-coated polysulphone capillary membranes for improved phenolic effluent bioremediation. Enzyme and Microbial Technology, 25, 769-773.

Halaouli, S., Asther, M., Sigoillot, J.-C., Hamdi, M., Lomascolo, A. (2006). Fungal tyrosinases: new prospects in molecular characteristics, bioengineering and biotechnological applications. Journal of Applied Microbiology, 100, 219-232.

Harris, E. L. V., Angal, S. (1989). Protein purification methods a practical approach. New York: Oxford University Press.

Jolivet, S., Arpin, N., Wichers, H. J., Pellon, G. (1998). Agaricus bisporus browning: a review. Mycological Research, 102, (12), 1459-1483.

Khan, A. A., Akhtar, S., Husain, Q., (2005). Simultaneous purification and immobilization of mushroom tyrosinase on an immunoaffinity support. Process Biochemistry, 40, 2379-2386. 
Kıralp, S., Toppare, L., Yağc1, Y. (2003). Immobilization of polyphenol oxidase in conducting copolymers and determination of phenolic compounds in wines with enzyme electrodes. International Journal of Biological Macromolecules. $33,37-41$.

Levenspiel, O. (1999). Chemical Reaction Engineering. USA: John Wiley \& Sons.

López-Gallego, F., Betancor, L., Hidalgo, A., Alonso, N., FernándezLafuente, R., Guisan, J. M. (2005). Co-aggregation of enzymes and polyethyleneimine: A simple method to prepare stable and immobilized derivatives of glutaryl acylase. Biomacromolecules, 5, 1839-1842.

López-Serrano, P., Cao, L., van Rantwijk, F., Sheldon, R. A. (2002). Crosslinked enzyme aggregates with enhanced activity: application to lipases. Biotechnology Letters, 24, 1379-1383.

Mateo, C., Palomo, J. M., van Langen, L. M., van Rantwijk, F., Sheldon, R. A. (2004). A new, mild cross-linking methodology to prepare cross-linked enzyme aggregates. Biotechnology and Bioengineering, 86 (3), 273-276.

Migneault, I., Dartiguenave, C., Bertrand, M. J., Waldron, K. C. (2004). Glutaraldehyde: behavior in aqueous solution, reaction with proteins, and application to enzyme cross-linking. BioTechniques, 37 (5), 790-802.

Munjal, N., Sawhney, S. K. (2002). Stability and properties of mushroom tyrosinase entrapped in alginate, polyacrylamide and gelatin gels. Enzyme and Microbial Technology, 30, 613-619.

Ögel, Z. B., Yüzügüllü Y., Mete, S., Bakir, U., Kaptan, Y., Sutay, D., Demir, A. S. (2006). Production, properties, and application to biocatalysis of a novel 
extracellular alkaline phenol oxidase from thermophilic fungus Scytalidium thermophilum. Applied Microbiology and Biotechnology, in press.

Okuda, K., Urabe, I., Yamada, Y., Okada, H. (1991). Reaction of glutaraldehyde with amino and thiol compounds. Journal of Fermentation and Bioengineering, 71 (2), 100-105.

Roy, J. J., Abraham, T. E. (2004). Strategies in making cross-linked enzyme crystals. Chemical Reviews, 104 (9), 3705-3721.

Schoevaart, R., Wolbers, M. W., Golubovic, M., Ottens, M., Kieboom, A. P. G., van Rantwijk, F., van der Wielen, L. A. M., Sheldon, R. A. (2004). Preparation, optimization, and structures of cross-linked enzyme aggregates (CLEAs). Biotechnology and Bioengineering, 87, (6), 754-762.

Scopes, R. K. (1988). Protein purification principles and practice, USA: Springer Verlag.

Seo, S.-Y., Sharma, V. K., Sharma, N. (2003). Mushroom tyrosinase: recent prospects. Journal of Agricultural and Food Chemistry, 51, 2837-2853.

Shah, S., Sharma, A., Gupta, M. N. (2006). Preparation of cross-linked enzyme aggregates by using bovine serum albumin as a proteic feeder. Analytical Biochemistry, 351, 207-213.

Smith, D. M., Montgomery, M. W. (1985). Improved methods for the extraction of polyphenol oxidase from d'Anjou pears. Phytochemistry, 24 (5), 901904.

Taylor, R. F. (1991). Protein immobilization, Fundamentals and Applications. New York: Marcel Dekker, Inc. 
Tyagi, R., Batra, R., Gupta, M. N. (1999). Amorphous enzyme aggregates: Stability toward heat and aqueous-organic cosolvent mixtures. Enzyme and Microbial Technology, 24, 348-354.

Van Gelder, C. W. G., Flurkey W. H., Wichers, H. J. (1997). Sequence and structural features of plant and fungal tyrosinases. Phytochemistry, 45 (7), 13091323.

Van Langen, L. M., Selassa R. P., van Rantwijk, F., Sheldon, R. A. (2005). Cross-linked Aggregates of (R)-Oxynitrilase: A stable, recyclable biocatalyst for enantioselective hydrocyanation. Organic Letters, 7 (2), 327-329.

Wada, S., Ichikawa, H., Tatsumi, K. (1993). Removal of phenols from wastewater by soluble and immobilized tyrosinase. Biotechnology and Bioengineering, 42, 854-858.

Walsh, G. (2002). Proteins Biochemistry and Biotechnology. West Sussex: John Wiley \& Sons, Ltd.

Wang, G., Xu, J.-J., Ye, L.-H., Zhu, J.-J., Chen, H.-Y. (2002). Highly sensitive sensors based on the immobilization of tyrosinase in chitosan. Bioelectrochemistry, 57, 33-38.

Wichers, H. J., Recourt, K., Hendriks, M., Ebbelaar, C. E. M., Biancone, G., Hoeberichts, F. A., Mooibroek, H., Soler-Rivas, C. (2003). Cloning, expression and characterisation of two tyrosinase cDNAs from Agaricus bisporus. Applied Microbiology and Biotechnology, 61, 336-341.

Wilson L., Illanes, A., Abián, O., Pessela, B. C. C., Fernández-Lafuente, R., Guisan, J. M. (2004). Co-Aggregation of penicillin G acylase and polyionic 
polymers: An easy methodology to prepare enzyme biocatalysts stable in organic media. Biomacromolecules, 5, 852-857.

Wilson, L., Betancor, L., Fernández-Lorente, G., Fuentes, M., Hidalgo, A., Guisán, J. M., Pessela, B. C. C., Fernández-Lafuente, R. (2004). Cross-linked aggregates of multimeric enzymes: A simple and efficient methodology to stabilize their quaternary structure. Biomacromolecules, 5, 814-817.

Xue, H., Shen, Z. (2002). A highly stable biosensor for phenols prepared by immobilizing polyphenol oxidase into polyaniline-polyacrylonitrile composite matrix. Talanta, 57, 289-295.

Yahşi, A., Şahin, F., Demirel, G., Tümtürk, H. (2005). Binary immobilization of tyrosinase by using alginate gel beads and poly(acrylamide-co-acrylic acid) hydrogels. International Journal of Biological Macromolecules, 36, 253-258.

Zaborsky, O. R. (1973). Immobilized enzymes. Ohio: CRC Press.

Zhang, X., van Leeuwen, J., Wichers, H. J., Flurkey, W.H. (1999). Characterization of tyrosinase from the cap flesh of portabella mushrooms. Journal of Agricultural and Food Chemistry, 47, 374-378. 


\section{APPENDIX A}

\section{BRADFORD METHOD}

Bradford Method is a rapid and sensitive method for quantitation of proteins using the principle of protein-dye binding. The binding of Coomassie Brillant Blue G-250 to proteins results in a shift in the absorption maximum of the dye from 465 $\mathrm{nm}$ (red form) to $595 \mathrm{~nm}$ (blue form). This method has a simple one step procedure in which Bradford reagent is added to the protein sample and the absorbance is measured at $595 \mathrm{~nm}$. The protein-dye complex has a high extinction coefficient. As a result, protein measurement can be performed with a great sensitivity. The binding of Coomassie Brillant Blue G-250 to proteins is very rapid, and the protein-dye complex stays dispersed in the solution for approximately 1 hour. Therefore, in this method no critical timing is necessary. Bradford method has a dependence on the amino acid composition of proteins since dye binding occurs primarily with basic and aromatic amino acid residues (Bradford, 1976; Harris and Angal., 1989).

Chemicals used to prepare concentrated stock reagent solution (5x stock) are given in Table A.1:

Table A.1: Chemicals required for the Bradford reagent

\begin{tabular}{|c|c|}
\hline Chemicals & Amount \\
\hline $85 \%$ ortho-phosphoric acid & $500 \mathrm{ml}$ \\
\hline $95 \%$ ethanol & $250 \mathrm{ml}$ \\
\hline Brillant Blue G- 250 & $500 \mathrm{mg}$ \\
\hline
\end{tabular}


Initially, Coomassie Brillant Blue G-250 was dissolved in ethanol. Then to this solution, ortho-phosphoric acid was added. The formed solution was diluted to 1 liter with distilled water. Produced $5 \mathrm{x}$ stock solution was stored at $4{ }^{\circ} \mathrm{C}$.

To prepare diluted $(1 \mathrm{x})$ reagent, 1 volume of the stock solution was mixed with 4 volumes of water. After efficient mixing, prepared reagent was filtered.

Bradford reagent should wait at room temperature for at least 24 hours before protein concentration measurement. 


\section{APPENDIX B}

\section{PROTEIN STANDARD PREPARATION FOR BRADFORD METHOD}

In the Bradford method, bovine serum albumin (BSA) was used as the standard protein. $25 \mathrm{mg}$ BSA was dissolved in $25 \mathrm{ml}$ of $0.1 \mathrm{M}, \mathrm{pH} 7.0$ sodium phosphate buffer in order to produce $1 \mathrm{mg} / \mathrm{ml}$ BSA stock solution. Then this stock solution was diluted with buffer to produce different protein concentrations. Dilution ratios and corresponding concentrations are shown in Table B.1.

Table B.1: Dilution ratios and concentrations of the BSA solutions

\begin{tabular}{|c|c|c|c|c|c|c|}
\hline $\begin{array}{c}\text { Protein concentration } \\
(\mathrm{mg} / \mathrm{ml})\end{array}$ & 0 & 0.01 & 0.02 & 0.03 & 0.04 & 0.05 \\
\hline BSA stock $(\mathrm{ml})$ & 0 & 0.1 & 0.2 & 0.3 & 0.4 & 0.5 \\
\hline Buffer (ml) & 10 & 9.9 & 9.8 & 9.7 & 9.6 & 9.5 \\
\hline
\end{tabular}

After preparation of diluted BSA solutions, $0.5 \mathrm{ml}$ samples from each of them were mixed with $5 \mathrm{ml}$ Bradford reagent in glass test tubes. After 10 minutes, absorbances at $595 \mathrm{~nm}$ were recorded by using spectrophotometer.

The protein standard curve for the Bradford method is given in Figure B.1: 


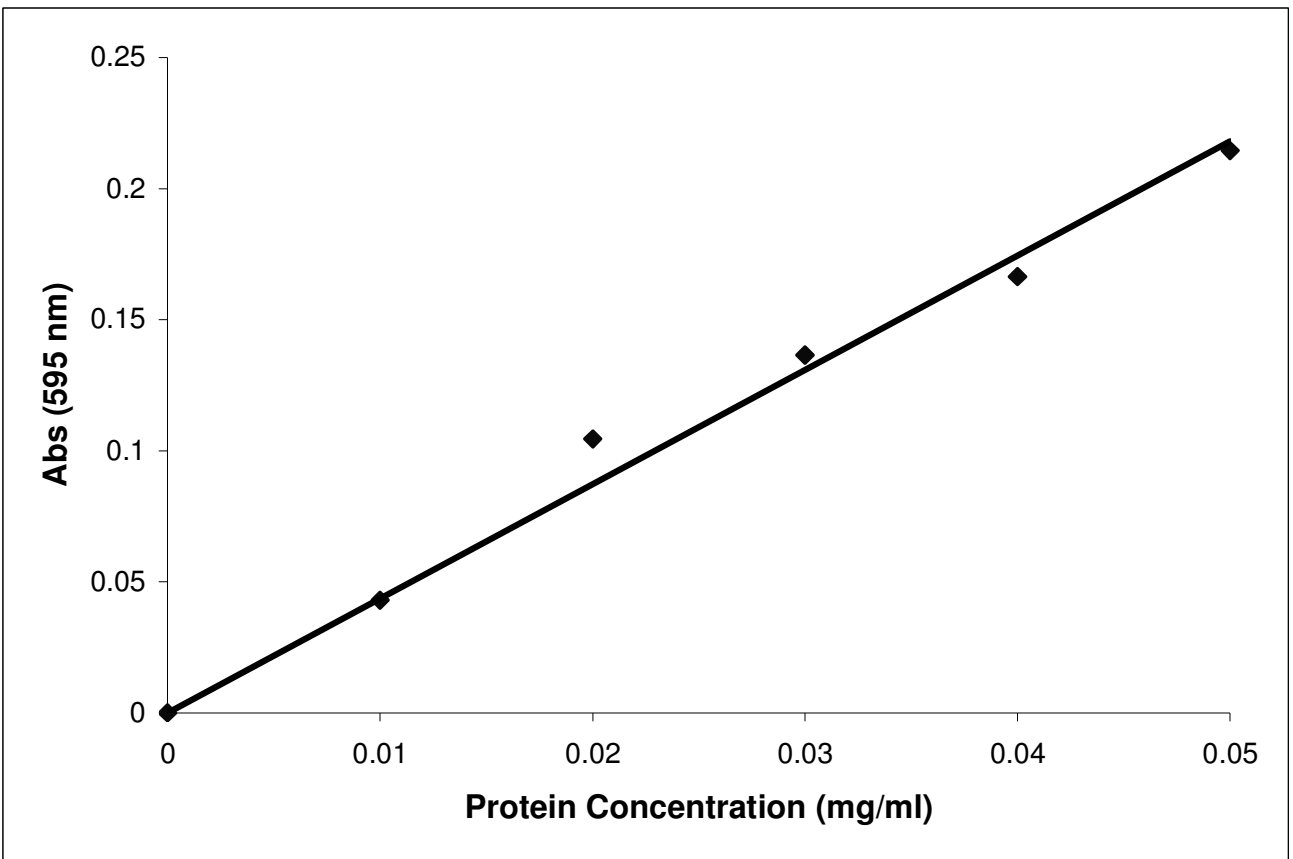

Figure B.1: Protein standard curve for the Bradford Method 


\section{APPENDIX C}

\section{FREE ENZYME INITIAL REACTION RATE CALCULATION}

To measure the initial reaction rate of the free enzyme, method given in Section 2.2.1 was followed. After the change of the absorbance with respect to time was recorded at $420 \mathrm{~nm}$, an absorbance versus time plot was constructed, as in Figure C.1.

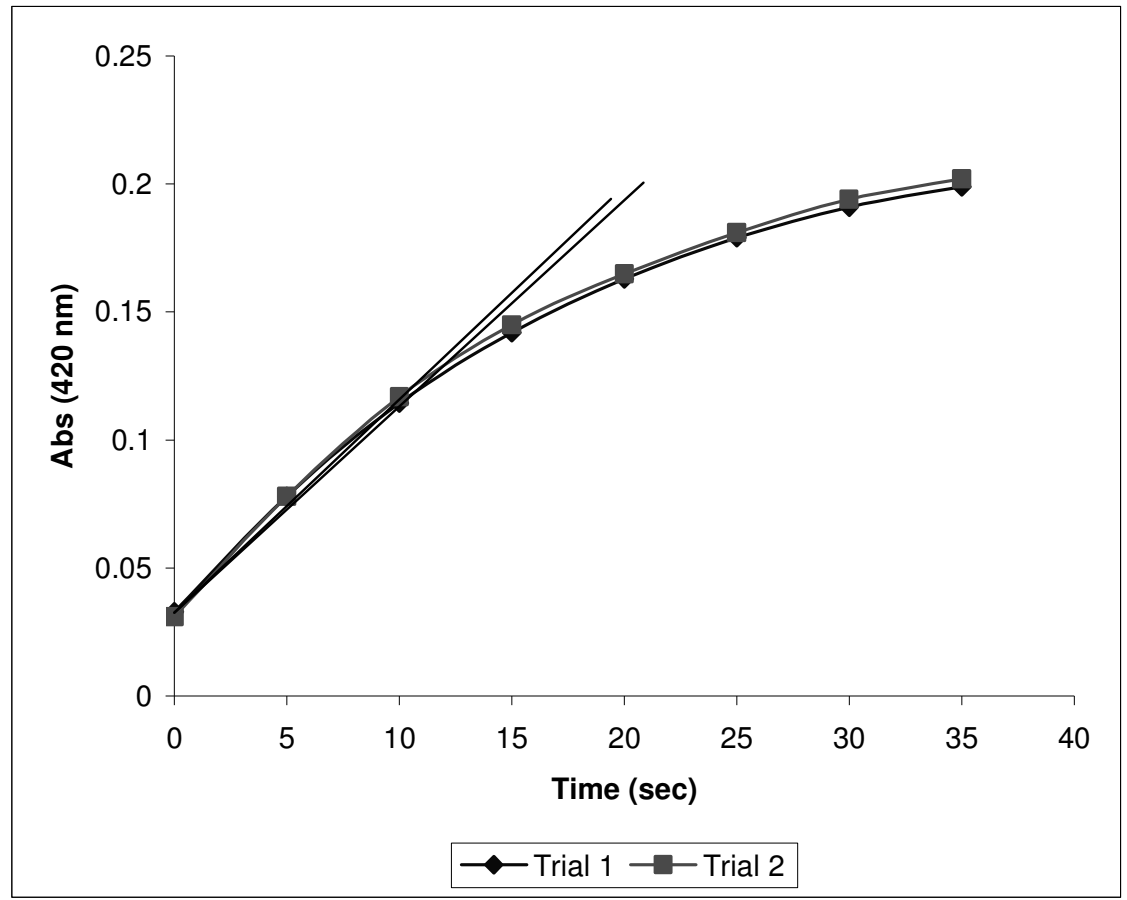

Figure C.1: Activity assay curve for the free enzyme. Pure tyrosinase $(1 \mathrm{mg} / \mathrm{ml})$ was diluted for 200 times before the assay. The reaction was started by the addition of 0.1 $\mathrm{M}$ catechol to the cuvette including the enzyme solution in $1 / 1$ ratio. 


\section{APPENDIX D}

\section{SEM IMAGES OF CLEAs}

In this part, the SEM images of CLEAs prepared with different AS and GA concentrations were given. The magnification in these images was selected as 500x in order to see the overall characteristic of the CLEA suspension.

$10 \mu \mathrm{l}$ of CLEA suspension was spread over a microscope slide. After drying at room temperature, CLEAs were coated with gold. The SEM images were recorded with JSM-6400 Electron Microscope (JEOL), equipped with NORAN System 6 Xray Microanalysis System \& Semafore Digitizer.

\section{Effect of Ammonium Sulfate Concentration}

The SEM images (500x) of CLEAs, prepared with 40, 60 and $80 \%$ AS saturations are given in Figures D.1, D.2, and D.3, respectively. In each case $1 \mathrm{mg} / \mathrm{ml}$ of tyrosinase, $50 \mathrm{mg} / \mathrm{ml}$ of BSA, and $2 \%(\mathrm{v} / \mathrm{v})$ GA were used. 


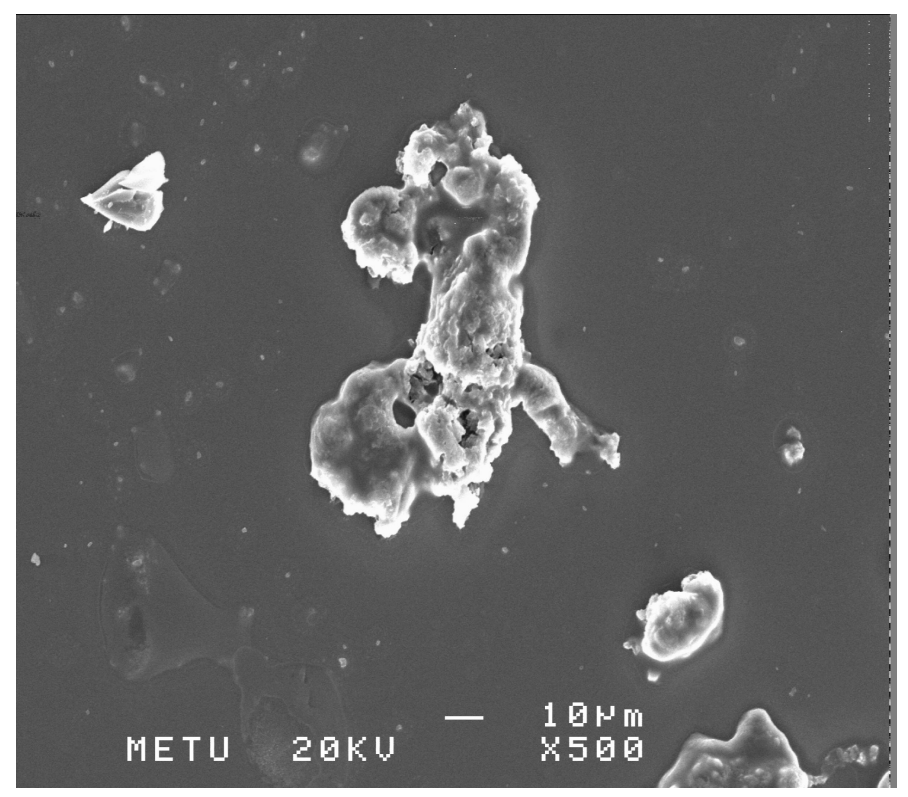

Figure D.1: SEM Image of CLEA produced with $40 \%$ saturated AS (magnification $500 x)$

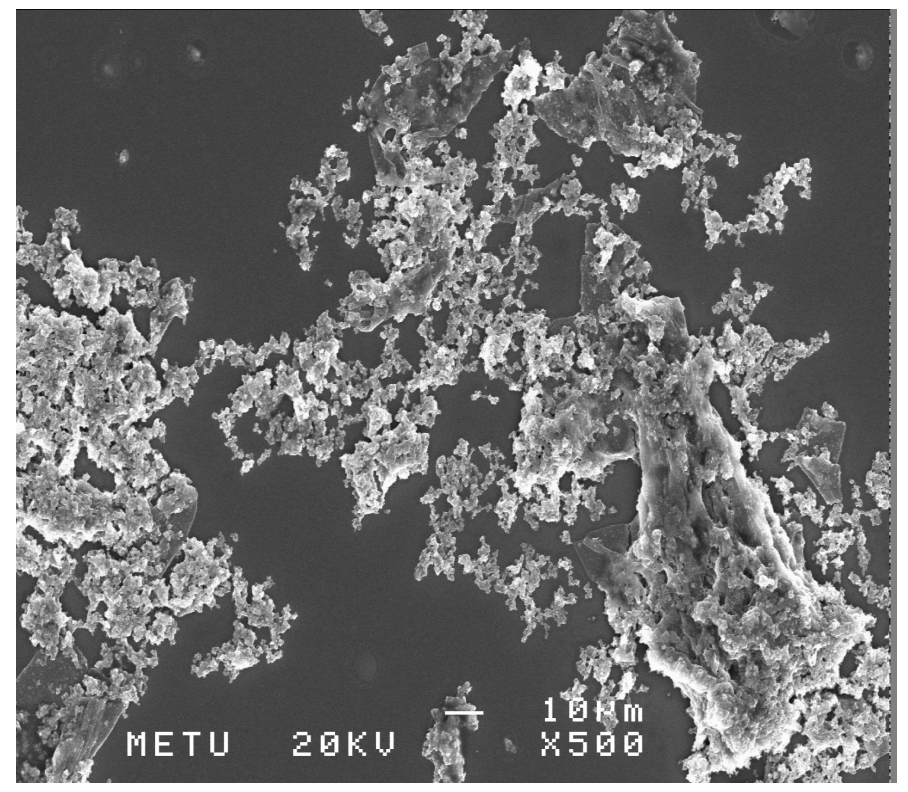

Figure D.2: SEM Image of CLEA produced with $60 \%$ saturated AS (magnification $500 x)$ 


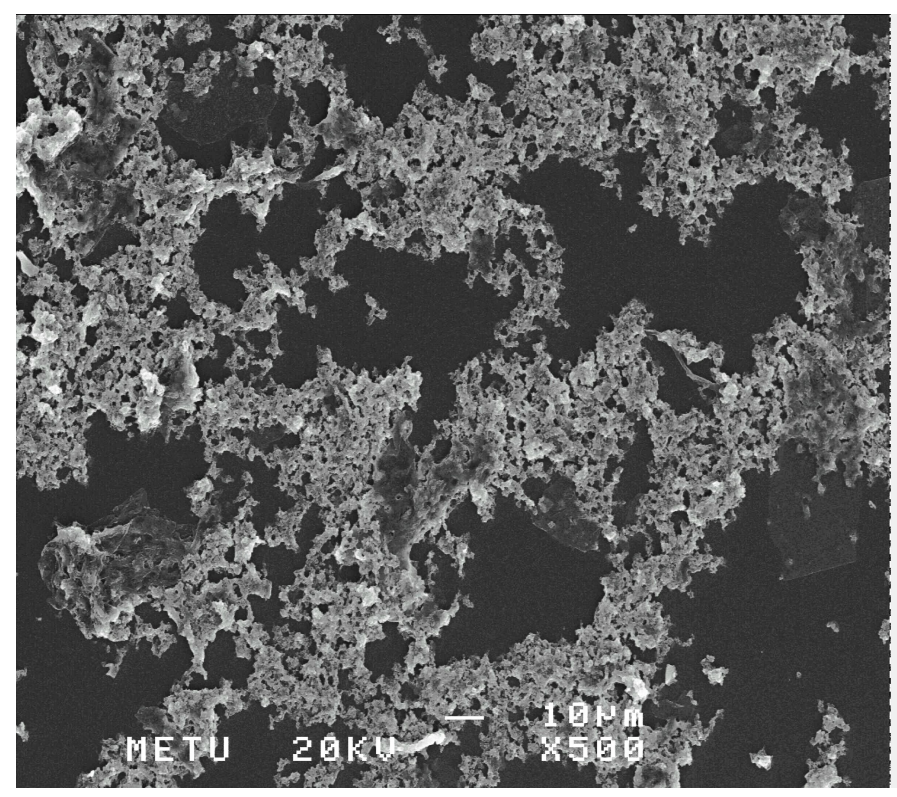

Figure D.3: SEM Image of CLEA produced with $80 \%$ saturated AS (magnification 500x)

\section{Effect of Glutaraldehyde Concentration}

The SEM images (500x) of CLEAs, prepared with two different GA concentrations, 1 and $2 \%(\mathrm{v} / \mathrm{v})$, are given in Figures D.4, and D.5, respectively. In each case, $1 \mathrm{mg} / \mathrm{ml}$ of tyrosinase, $50 \mathrm{mg} / \mathrm{ml}$ of BSA, and $60 \%$ saturated AS were used. 


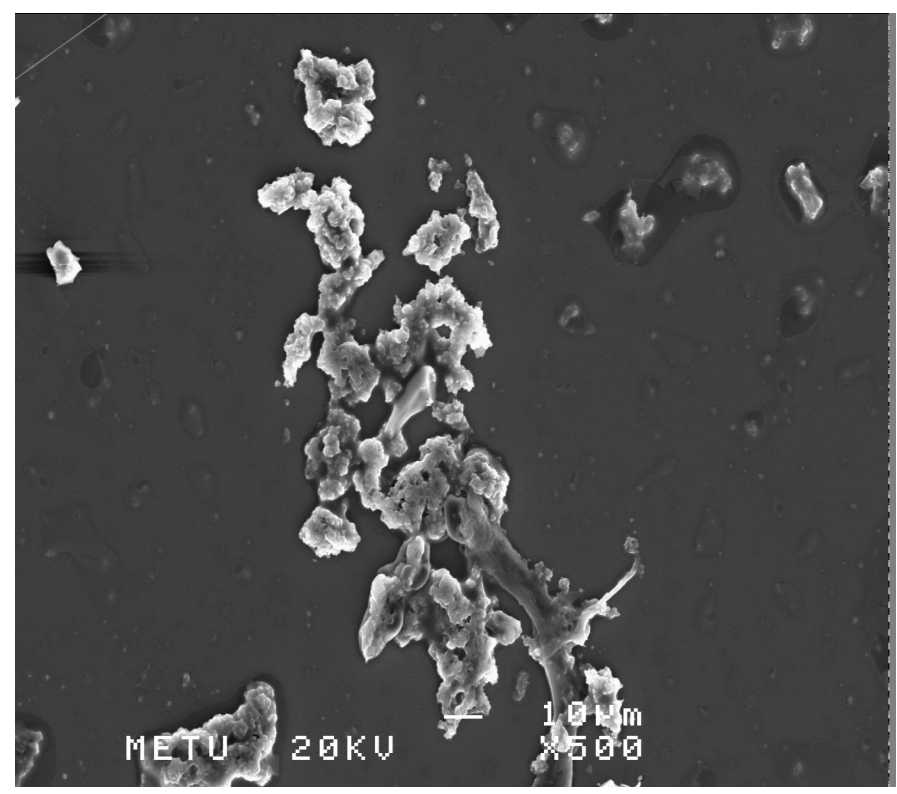

Figure D.4: SEM Image of CLEA produced with $1 \%(\mathrm{v} / \mathrm{v})$ GA (magnification $500 x)$

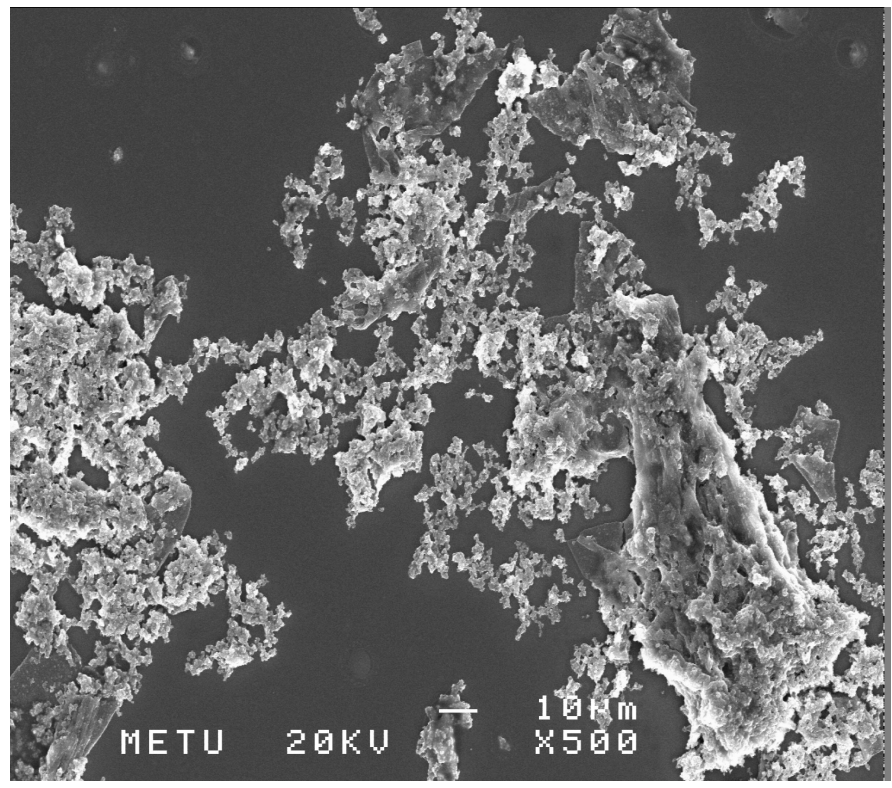

Figure D.5: SEM Image of CLEA produced with $2 \%(\mathrm{v} / \mathrm{v})$ GA (magnification $500 x)$ 


\section{APPENDIX E}

\section{TWO-WAY ANOVA OF THE EFFECT OF STORAGE TEMPERATURE ON THE CLEA ACTIVITY}

Statistical analysis of the effect of the storage temperature $\left(4{ }^{\circ} \mathrm{C}\right.$ and room temperature) on CLEA activity was performed by ANOVA-two factor with replication by utilizing Microsoft, Excel. Obtained data is shown in Table E.1.

Table E.1: ANOVA of the effect of storage temperature on the CLEA activity

\begin{tabular}{|c|c|c|c|c|c|c|}
\hline ANOVA & & & & & & \\
\hline Source & SS & df & MS & F & P-value & F crit \\
\hline Storage Day & 768.83 & 6 & 128.14 & 21.46 & $2.63 \mathrm{E}-06$ & 2.85 \\
\hline $\begin{array}{c}\text { Storage } \\
\text { Temperature }\end{array}$ & 2.16 & 1 & 2.16 & 0.36 & 0.56 & 4.60 \\
\hline Interaction & 49.37 & 6 & 8.23 & 1.38 & 0.29 & 2.85 \\
\hline Within & 83.60 & 14 & 5.97 & & & \\
\hline & & & & & & \\
\hline Total & 903.95 & 27 & & & & \\
\hline
\end{tabular}

